STIPPEL, Jörg; SERRANO, Juan. "La nacionalización

de la lucha contra el narcotráfico en Bolivia".

Polít. crim. Vol. 13, No 25 (Julio 2018) Art. 8, pp. 264-321.

[http://www.politicacriminal.cl/Vol_13/n_25/Vol13N25A8.pdf]

\title{
La nacionalización de la lucha contra el narcotráfico en Bolivia
}

The nationalization of the fight against drug trafficking in Bolivia

\author{
Jörg Stippel \\ Investigador Universidad Central de Chile \\ Doctor en Derecho Universidad de Bremen \\ jorg.stippel@ucentral.cl \\ Juan Enrique Serrano Moreno \\ Escuela de Derecho, Universidad Bernardo OHiggins \\ Doctor en Ciencia Política Universidad París 1 Panthéon-Sorbonne \\ Investigador Asociado del CEPEL Universidad Montpellier 1 \\ juane.serrano@ubo.cl
}

\section{Resumen}

El estudio de las políticas en materia de control de drogas en Bolivia es un objeto de vital relevancia para entender la evolución política del país desde la vuelta de la democracia en 1982. La Ley 1008 de 1988 reforzó la militarización de la política criminal inspirado en la doctrina de la seguridad nacional y la amalgama entre cultivo, consumo y narcotráfico impuestos por las Convenciones de la ONU para el control de drogas. Los conflictos sociales y políticos que siguieron en defensa del cultivo de coca favorecieron la movilización de organizaciones campesinas que terminaron por llevar al poder al MAS en 2006. Este artículo analiza la construcción de una política anti-narcotráfico militarizada e impuesta desde el exterior y su posterior desmantelamiento en nombre de la soberanía nacional y la prevención del consumo a partir del análisis del derecho positivo, datos estadísticos, informes y prensa.

\section{Palabras clave}

Bolivia, drogas, narcotráfico, convenciones internacionales, política criminal.

\begin{abstract}
The study of drug policies in Bolivia is of vital importance to understand its political evolution since the return to democracy in 1982. The Law 1008 of 1988 reinforced the militarization of criminal policy inspired by doctrine of national security and the amalgam between cultivation, consumption and drug trafficking imposed by the UN international drug control conventions. The social and political conflicts that followed defending the cultivation of the coca leaf favored the mobilization of peasant organizations that eventually paved the path to power for MAS in 2006. This article analyzes the construction of a militarized anti-drug policy imposed from abroad and its posterior dismantling in the
\end{abstract}


Polít. crim. Vol. 13, № 25 (Julio 2018) Art. 8, pp. 264-321.

[http://www.politicacriminal.cl/Vol_13/n_25/Vol13N25A8.pdf]

name of national sovereignty and prevention analyzing positive law, statistical data, reports and press.

\section{Key words}

Bolivia, drugs, traffic, international coventions, crime policy.

\section{Introducción}

En las últimas dos décadas Bolivia ha sido uno de los países de América Latina que ha vivido las transformaciones políticas y sociales más profundas convirtiéndose en un objeto de estudio privilegiado para las ciencias sociales. ${ }^{1}$ Poco conocemos sin embargo de su política criminal, ${ }^{2}$ ámbito central para el proyecto de recuperación de la soberanía que llevó al poder al Movimiento al Socialismo (en adelante MAS) en 2006. Existe pues un vacío en la literatura en derecho penal y criminología sobre el funcionamiento real del sistema judicial boliviano debido en gran medida a la escasez de datos públicos, confiables y actualizados. ${ }^{3}$ En este contexto, este artículo analiza la evolución de la política antidrogas boliviana desde los comienzos de la fiscalización tras la ratificación de la Convención Única en 1961 hasta su desmilitarización y nacionalización iniciada en $2006^{4}$ centrándonos en especial en la política relacionada a la hoja de coca y la cocaína.

A grandes rasgos, en Bolivia la política antidrogas ha transitado desde el paradigma del

\footnotetext{
${ }^{1}$ A modo de introducción sobre el caso boliviano, podemos citar entre otros muchos estudios existentes de ciencia política, sociología, historia y antropología sobre los cambios sociales y políticos experimentados desde finales del siglo XX en Bolivia: GUTIÉRREZ, Raquel, Los ritmos del Pachakuti. Movilización y levantamiento indígena-popular en Bolivia (2000-2005), Buenos Aires: Tinta Limón, 2008 passim; IGLESIAS, Pablo; ESPASANDÍN, Jesús (coords.), Bolivia en Movimiento. Acción Colectiva y Poder Político, Barcelona: El Viejo Topo, 2007 passim; TAPIA, Luis, Política salvaje, La Paz: CLACSO, 2008 passim; La invención del núcleo común. Ciudadanía y gobierno multisocial, La Paz: Muela del Diablo Editores, 2006 passim; ALBÓ, Xavier, Movimientos y poder indígena en Bolivia, Ecuador y Perú, La Paz: CIPCA, 2008 passim.

2 Adoptamos así el enfoque criminológico en el que, tomando prestadas las palabras de Fernández Carrasquilla, "todo el Derecho penal - por tanto, delito y pena - es la concreción de una determinada política criminal; delito y pena son entonces fenómenos sociales de índole político - jurídica. El establecimiento legal de delitos y penas no es una actividad especulativa, sino política, en cuya virtud el Estado, interpretando o acogiendo las valoraciones de la comunidad o de los sectores predominantes de esta, otorga protección penal a determinados intereses, generalmente conocidos como bienes jurídicos." Fernández Carrasquilla, Juan, "Alternativa en la política criminal de las drogas en América Latina", Anuario de derecho penal y ciencias penales, Tomo 41 (1988), pp. 387-412, p. 391.

${ }^{3}$ STIPPEL, Jörg; SERRANO MORENO, Juan E., "Veinte años de reformas sin rumbo. De la reforma procesal penal a la cumbre de justicia en Bolivia", Nova Criminis, nº 12, vol. 8 (diciembre 2016), pp. 33-75.

${ }^{4}$ Para una visión comparada del impacto de las políticas antidrogas en América Latina desde la perspectiva de la proporcionalidad de las penas, véase PALADINES, Jorge Vicente, El Equilibrio Perdido: drogas y proporcionalidad en las justicias de América, Quito: Defensoría Pública del Ecuador, 2013 passim. Por su lado, Hermosilla critica el impacto de la ley de drogas de Chile (Ley No. 20.000) en "jóvenes marginales" y mujeres, opinando que "el problema no son las drogas, sino la política de control de drogas". Entrevista a Juan Pablo Hermosilla". HERMOSILLA, Juan Pablo; "Política de Control de Drogas. Reformas urgentes hacia la Descriminalización", Nova Criminis, no 8, vol. 5 (diciembre 2014), pp. 31 -57, pp. 35 y 39.
} 


\section{STIPPEL, Jörg; SERRANO, Juan. "La nacionalización de la lucha contra el narcotráfico en Bolivia".}

prohibicionismo ${ }^{5} \mathrm{y}$ de la "guerra total" contra las drogas, a una de jure y de facto descriminalización, ${ }^{6}$ para llegar finalmente a una regulación y despenalización parcial. La nueva política criminal se construyó desde 2006 a partir de la disociación entre cultivo, consumo y tráfico de la hoja de coca. Al contrario que en otros países, el debate público no se concentró en el derecho al consumo de drogas - Recht auf Rausch ${ }^{7}$ - o el rol del Estado en la protección de la salud pública. ${ }^{8}$ Los actores convirtieron la lucha para la legalización de la hoja de coca en una cuestión de identidad y soberanía nacional. Paralelo a ello, el gobierno comenzó a cambiar el discurso público sobre drogas poniendo el acento en la prevención a través de una nueva institucionalidad pública especializada. El presente trabajo analiza el desarrollo de la política anti-drogas que permitió este cambio de paradigma, así como las tensiones diplomáticas ocasionadas por ello entre Bolivia y la comunidad internacional. ${ }^{9}$

A pesar de los avances alcanzados, en nuestra opinión, el proceso de nacionalización de las ${ }^{5}$ Desde una perspectiva internacional, el Transnational Institute describe la historia de la prohibición del
cannabis. El estudio entrega argumentos jurídicos para abogar a favor de una reforma de los tratados
internacionales. TRANSNATIONAL INSTITUTE, Auge y caída de la prohibición del cannabis. La historia
del cannabis en el sistema de control de drogas de la ONU y opciones de reforma, TNI: Amsterdam, 2014, p.
70 , en: https://www.tni.org/files/download/auge-y-caida-web.pdf [visitado el 07.05.2017].
${ }^{6}$ Rosa del Olmo explica que la descriminalización puede ser de dos tipos: "la descriminalización de jure, por
medio de la cual no se cambia la ley, pero simplemente no se aplica, y la descriminalización de facto, donde
tampoco cambia la ley pero se aplica menos severamente". DEL OLMO, Rosa, ¿Prohibir o domesticar?
Políticas de drogas en América Latina, Caracas: Editorial Nueva Sociedad, 1992, p. 120.
${ }^{7}$ El Tribunal Constitucional de la República Federal de Alemania resolvió en 1994 que "no existe un
"derecho a drogarse" (BVerfGE 90, 145). El juez de Wolfgang Nescovic de la Corte Superior de Alemania
(OLG) opinaba que su decisión dependía de la constitucionalidad de una norma de la Ley Alemana de
Estupefacientes (Art. 29 I. Nr. 1 Betäubungsmittelgesetz). En su resolución entrega argumentos para un
derecho a drogarse y argumenta, entre otros, una vulneración de la igualdad ante la ley. Pero el Tribunal
Constitucional tampoco aceptó este argumento, pues establecía que "el principio de igualdad no obliga a
prohibir o autorizar de la misma manera toda droga que potencialmente sea igual de dañina. El legislador
puede, sin violar la Constitución, regular de manera diferente el comercio de productos de cannabis de una
parte, y de alcohol o nicotina de la otra". La sentencia se encuentra traducida FUNDACIÓN KONRAD
ADENAUER, Jurisprudencia del Tribunal Constitucional Federal Alemán. Extractos de las sentencias más
relevantes compiladas por Jürgen Schwabe, KAS: México DF, 2009, en
http://www.kas.de/wf/doc/kas 16817-544-4-30.pdf [visitado el 07.05.2017] p. 104 y s.

${ }^{8}$ A este respecto, Hermosilla critica la legislación de drogas en pos de la protección de la salud pública porque el Estado sanciona "a un adulto con la excusa de que está consumiendo algo que le hace mal a él mismo". Y se pregunta " ¿dónde está el límite de eso? La sal me hace mal, la sal me puede matar, el azúcar me puede matar, el exceso de trabajo me puede matar, subir cerros y andar en moto me puede matar. ¿Eso se lo voy a atribuir al Estado? Eso es una cuestión técnicamente totalitaria. Le voy a permitir y reconocer al Estado, por sobre mi libertad de autodeterminación, la facultad de decirme qué voy a consumir o no?". HERMSOILLA, "Política", cit. nota nº 4, p. 40.

${ }^{9}$ Sobre otras experiencias internacionales véase el trabajo de Sáenz Uribe donde contextualiza la experiencia colombiana en vista de la experiencia de los Estados Unidos y Argentina por un lado y Holanda y España por el otro. SÁENZ URIBE, Sara, "Consumo de drogas ilícitas, ¿prohibición o regulación?. Análisis del caso colombiano en perspectiva de política comparada", Revista Facultad de Derecho y Ciencias Políticas, vol. 39, núm. 111, (julio-diciembre, 2009), pp. 253-282, en: http://www.redalyc.org/pdf/1514/151412839003.pdf [visitado el 07.05.2017], p. 256 y s. Para una descripción del desarrollo histórico de la política de drogas a nivel internacional, véase DIÉZ RIPOLLES, José Luis, "El control penal del abuso de drogas: una valoración político-criminal", Revista de derecho de la Universidad Austral de Chile, vol.18, n¹ (2005), pp. 199-212, en: $\quad$ http://www.scielo.cl/scielo.php?script=sci_arttext\&pid=S0718-09502005000100008,,$\quad$ [visitado el 07.05.2017], p. 199 y s. 
Polit. crim. Vol. 13, № 25 (Julio 2018) Art. 8, pp. 264-321.

[http://www.politicacriminal.cl/Vol_13/n_25/Vol13N25A8.pdf]

políticas relacionadas a las drogas recién comenzó con la legalización del "cato de coca" en 2004. A su vez observamos que el balance del la reorientación implementada hasta la fecha arroja resultados contradictorios tales como la explosión de la cantidad de droga incautada, una reducción de personas aprehendidas por delitos relacionados con el narcotráfico y una tasa de encarcelamiento en constante aumento aparejada de una disminución del porcentaje de personas recluidas por narcotráfico en relación al conjunto de la población reclusa.

Este estudio ha sido elaborado a partir de fuentes provenientes del derecho nacional e internacional, artículos periodísticos, ensayos históricos, estadísticas producidas por organismos públicos y la abundante "literatura gris" producida por el gobierno boliviano, organizaciones internacionales y actores clave multiposicionados en los campos políticos, académicos y de la cooperación internacional.

\section{La imposición de la política criminal antidrogas}

\subsection{La Convención Única de 1961}

El filosofo boliviano José Antonio Quiroga afirma que desde los tiempos de la Colonia, los cultivos de coca han sido objeto de controversias sobre si deben o no reducirse y en que magnitudes. Opina que desde entonces, las decisiones más importantes a este respecto han sido adoptadas fuera del país. ${ }^{10}$

Este fue el caso de la Convención Única sobre Estupefacientes de las Naciones Unidas de 1961 (en adelante Convención Única) que contempla, por primera vez a nivel internacional, la hoja de coca y la planta de cannabis como sustancias sujetas a fiscalización ${ }^{11}$. La normativa obliga a los países firmantes a "arrancar de raíz todos los arbustos de coca que crezcan en estado silvestre y destruirán los que se cultiven ilícitamente", si bien, para no pedir algo imposible, se debía actuar "en la medida de los posible" ${ }^{12}$. Es necesario contextualizar estas disposiciones a la luz del preámbulo de la convención donde se informa que las partes la suscribieron porque estaban "preocupadas por la salud física y moral de la humanidad". En el mismo preámbulo se reconoce que la "toxicomanía constituye un mal grave para el individuo y entraña un peligro social y económico para la humanidad". De esto se desprende que la Convención Única pretendía proteger prioritariamente la salud pública.

A pesar del compromiso asumido a nivel internacional con la firma de la Convención Única, la ley de drogas de Bolivia (Ley 171 del 10 de enero 1962), no cataloga la hoja de coca como estupefaciente al contrario que a la cocaína, además solo menciona la

\footnotetext{
${ }^{10}$ QUIROGA, José Antonio, Coca/Cocaína. Una visión boliviana, La Paz: AIPE-PROCOM/CEDLA/CID, 1990, en: https://www.cedla.org/sites/default/files/M-0858_coca_cocaina_una_vision_boliviana.pdf [visitado el 07.05.2017], p. 52.

11 Art. 2 pár. 1 y Lista I. de la Convención Única de 1961. El texto está disponible en: https://www.incb.org/documents/Narcotic-Drugs/1961-Convention/convention_1961_es.pdf [visitado el 07.05.2017].

${ }^{12}$ Art. 26 pár. 2. de la Convención Única de 1961.
} 


\section{STIPPEL, Jörg; SERRANO, Juan. "La nacionalización de la lucha contra el narcotráfico en Bolivia".}

"ecgonina", sustancia que se encuentra en las hojas de coca, pero no la hoja en sí. ${ }^{13}$ Fue recién el gobierno de Hugo Banzer - quien subió al poder tras un golpe de Estado en $1971^{14}$ - que, "en defensa de la salud y la moral del pueblo boliviano", promulga la Ley de Control de Sustancias Peligrosa en $1973^{15}$, clasificando al arbusto y la hoja de coca como estupefacientes. ${ }^{16}$ Vemos así que la legislación boliviana, al igual de la Convención Única, invoca la salud como justificación de la norma, a lo que añade la moral.

Contrariamente a la impresión que dejan los instrumentos legales aprobados en esta época, varios autores señalan que es bajo el gobierno de facto de Banzer cuando comienza a estructurarse la industria de la cocaína. ${ }^{17}$ Esto se debió a las presiones internacionales ejercidas sobre el gobierno de Banzer que decretó la erradicación paulatina del cultivo de coca, creó la Dirección Nacional para el Control de Sustancias Peligrosas y revisó la Ley de Narcóticos. En 1976, familiares cercanos de Banzer reorganizaron el negocio de la cocaína construyendo la infraestructura necesaria para ello. ${ }^{18}$ Parece paradójico que, es en ese

${ }^{13}$ El artículo 1 de la Ley 171 estipula: "Para objeto y fines de la presente ley se consideran estupefacientes: a. El opio bruto y opio medicinal en todas sus formas; b. Los alcaloides derivados del opio; c. Los sucedáneos de la morfina; d. La cocaína bruta y sus derivados; e. La ecgonina; f. El cáñamo indico y sus preparaciones galénicas; g. Los preparados medicinales y no medicinales derivados de los alcaloides anteriormente enumerados". El comercio, la elaboración y el suministro de estupefacientes se sancionaba con presidio de tres a diez años y la posesión de estupefaciente con presidio de tres a cinco años: Art. 2 y 3 de la Ley 171, en: http://www.lexivox.org/norms/BO-L-171.xhtml [visitado el 07.05.2017].

${ }^{14}$ El sociólogo Federico Aguiló transcribe parte de los testimonios de los presos políticos detenidos y caracterizando el gobierno de Banzer como "uno de los períodos más negros de la Historia Boliviana". El autor contabilizó 429 personas muertas en enfrentamientos y masacres durante el régimen de Banzer. AGUILÓ, Federico, “Nunca Más” para Bolivia, Cochabamba: APDHB, 1993, pp. 121; 141-147 y 183.

15 Decreto Ley 11245 del 20 de diciembre 1973, en http://www.derechoteca.com/gacetabolivia/decretosupremo-11245-del-20-diciembre-1973/ [visitado el 07.05.2017].

${ }^{16}$ Quiroga señala que posteriormente, en 1974, se aprobó un primer proyecto piloto de 8 millones de dólares financiados por los Estados Unidos, para determinar la factibilidad de un programa que controlara y redujera la producción de coca en el país. A raíz de ello se firmaron acuerdos bilaterales (1977, 1978 y 1979) en los que Estados Unidos proporcionaba una sustanciosa ayuda financiera a la DNCSP en la lucha contra el tráfico de cocaína. QUIROGA, Coca, cit. nota nº 10, p. 56.

${ }^{17}$ El historiador Mesa Gisbert afirma que el negocio del narcotráfico "había nacido con fuerte impulso en el gobierno de Banzer y sentado reales con García Mez”. Es entonces cuando ".los relocalizados llegaron al Chapare (el propio Morales entre ellos) como mano de obra fresca y barata”. MESA GISBERT, Carlos D., Bolivia 1982-2006. Democracia, La Paz: Editorial Gisbert y CIA S.A., 2017, p. 79. Por su lado, el economista Roberto Laserna restituye las posiciones de los distintos autores bolivianos acerca del nivel de participación de las dictaduras en el narcotráfico. LASERNA, Roberto, El fracaso del prohibicionismo Estudios socioeconómicos para una historia de las políticas antidrogas en Bolivia, La Paz: Fundación Vicente Pazos Kanki, 2011, en: http://www.bivica.org/upload/politicas-antidrogas.pdf [visitado el 07.05.2017]. pp. 60-67.

${ }^{18}$ El autor británico Pete Good analiza las relaciones familiares de Banzer y sus vínculos con el narcotráfico. Destaca el rol del yerno y posterior prófugo de la justicia boliviana Luis Alberto "Chito" Valle, actualmente encarcelado en Bolivia por cargos de corrupción cometidos durante su gestión de gobernador de La Paz entre 1997 y 1999, después de ser extraditado desde Perú en 2010. GOOD, Pete, Bolivia-Between a Rock and a Hard Place, La Paz: Plural Editores, 2006, pp. 158-162. Rosa del Olmo entrega la misma información citando a los autores bolivianos William Carter, Mauricio Mamani y René Bascopé Aspiazu. DEL OLMO, ¿Prohibir o domesticar?, cit. nota $\mathrm{n}^{\mathrm{o}}$ 6, p. 81. Cabe señalar que a nivel regional, en otros países como Chile, el servicio de inteligencia del ejército (DINA) financió parte de sus actividades ilegales con el narcotráfico. El Ciudadano, "La Corte Suprema dicta sentencia definitiva en el caso del químico de la DINA Eugenio Berríos”, 12 de agosto 2015, en http://www.elciudadano.cl/justicia/la-corte-suprema-dicta-sentenciadefinitiva-en-el-caso-del-quimico-de-la-dina-eugenio-berrios-conoce-su-macabra-historia/08/12/ [visitado el 07.05.2017]. 
Polit. crim. Vol. 13, № 25 (Julio 2018) Art. 8, pp. 264-321.

[http://www.politicacriminal.cl/Vol_13/n_25/Vol13N25A8.pdf]

mismo año, 1976, cuando se firma el primer Convenio Económico entre Bolivia y Estados Unidos, donde éstos comprometen apoyo para programas de lucha contra el consumo, tráfico y la comercialización de estupefacientes. ${ }^{19}$ Desde una visión menos legalista, el economista boliviano Roberto Laserna afirma que el endurecimiento de la legislación antinarcótica durante los gobiernos de facto acusados de vinculación con el narcotráfico es producto de la necesidad de éstos de demostrar su repudio al narcotráfico mediante la adopción de los instrumentos legales que dieran fe de ello. ${ }^{20}$

Los datos disponibles confirman, en las palabras del historiador y ex-presidente boliviano Carlos Mesa Gisbert, que los años ochenta marcaron con el crecimiento masivo del narcotráfico "un hecho de trascendencia histórica dramática y determinante para la realidad social, económica y moral del país". ${ }^{21}$ Este fenómeno quedó patente en el espacio público con el escándalo que representó la acusación del gobierno de facto de Luis García Mesa y específicamente de su ministro del Interior Luis Arce Gómez ${ }^{22}$ de estar involucrado en el narcotráfico. Cabe señalar en el mismo sentido la famosa oferta realizada al gobierno por el "Rey de la Cocaína" Roberto Suarez Gómez, primo del ministro Suárez, por la que se comprometía a pagar la deuda externa de Bolivia si liberaban a su hijo. ${ }^{23}$

A la luz de los datos oficiales la producción de la hoja de coca en Bolivia creció continuamente por aquel entonces. Si en 1963 se producían 4,8 toneladas de hojas de coca, esta cifra subió a 38,3 toneladas en 1981, para llegar a 136, 8 toneladas en $1988 .{ }^{24}$ A su vez un número creciente de personas vivía de la producción de la hoja de coca. Si en 1950 habían 2.929 productores de hoja de coca para el consumo tradicional, eso número habría

19 TELLERÍA, Loreta; GONZÁLES, Reina, Hegemonía Territorial Fallida-Estrategias de control y dominación de Estados Unidos en Bolivia: 1985-2012, La Paz: CIS, 2015, p. 69.

${ }^{20}$ LASERNA, El fracaso, cit. nota ${ }^{\circ} 17$, p. 66 y siguientes.

${ }^{21}$ MESA GISBERT, Carlos D., Historia de Bolivia, La Paz: Novena edición, Editorial Gisbert y CIA S.A., 2016 (1997), p. 729.

${ }^{22}$ Luis Arce Gómez fue capturado y deportado a Estados Unidos en 1989. Mesa Gisbert relata que su extradición desató una gran polémica a nivel nacional que llevó a Bolivia a no firmar un nuevo tratado de extradición. MESA GISBERT, Carlos D., Presidencia sitiada. Memorias de mi Gobierno, La Paz: Quinta edición, Plural editores, Quinta edición 2013 (2008), p. 668. En su juicio por conspiración para importar cocaína a Estados Unidos, Arce Gómez afirmó que su propósito había sido el de desterrar de Bolivia a los traficantes de drogas extranjeros, en el mismo momento en que ejercía un estricto control sobre la distribución legal de coca en su propia nación. Se le condenó a una pena de 25 años. Arce Gómez egresó de la cárcel en Estados Unidos el 23 de noviembre de 2007. Actualmente está cumpliendo una condena de 30 años en Bolivia por distintos delitos cometidos durante la dictadura de García Mesa. El Tiempo, "Condenado Arce Gómez por tráfico de cocaína", 10 de enero 1991, en http://www.eltiempo.com/archivo/documento/MAM7883 [visitado el 07.05.2017]; El País, “Un ex ministro boliviano cumple condena por genocidio", 9 de julio 2009, en: http://internacional.elpais.com/internacional/2009/07/09/actualidad/1247090415_850215.html [visitado el 07.05.2017]. Cabe mencionar que Arce Gómez se encuentra actualmente registrado en el sistema penitenciario estadounidense con el número 41663-004 que consta en el portal de Federal Bureau of Prisions en: https://www.bop.gov/inmateloc/ [visitado el 07.05.2017].

${ }^{23}$ Muchas historias de Suarez salieron a la luz gracias a la recopilación y publicación de su esposa. El Clarín, "Cuando el "Rey de la Cocaína" fundó el primer narcoestado", 25 de noviembre 2012, en: https://www.clarin.com/mundo/Rey-Cocaina-fundo-primer-narcoestado_0_B18GTBaiDmg.html [visitado el 07.05.2017].

${ }^{24}$ Datos citados por QUIROGA, Coca, cit. nota $n^{\circ} 10$, p. 82. 


\section{STIPPEL, Jörg; SERRANO, Juan. "La nacionalización de la lucha contra el narcotráfico en Bolivia”.}

subido a 61.641 productores el año $1987 .{ }^{25}$ Ese aumento lleva relación con el incremento del precio. Mesa Gisbert señala a este respecto que el "tambor de coca" - equivalente a 100 libras - costaba 180 dólares estadounidenses en 1975 para subir a 600 en 1980, legando a su pico de 800 dólares en $1983 .{ }^{26}$

Lo que nos muestra la historia boliviana, es que la ratificación de la Convención Única contra Estupefacientes de 1961 y su posterior implantación en la legislación nacional en 1962 y 1973, no han contribuido aparentemente a una lucha más eficiente contra las sustancias prohibidas. Todo lo contrario, desde entonces floreció el negocio ilegal. Tendencia que se asentó en los años siguientes.

\subsection{El camino hacía la Convención de 1988}

En 1985, con la elección de Víctor Paz Estenssoro comenzó a configurarse un particular diseño político en Bolivia que más tarde recibiría el nombre de "democracia pactada". En este sentido, el cientista político René Antonio Mayorga destaca que esta lógica de acuerdos y consensos reemplazó "la lógica tradicional de guerra implacable entre los adversarios políticos". ${ }^{27}$ Siguiendo esta perspectiva, podríamos considerar que un "consenso nacional" fue concluido para dar la máxima prioridad a la lucha contra las drogas. Sin embargo, tal y como veremos más adelante, la existencia de dicho "consenso" es cuestionable, o al menos solo tuvo lugar entre las élites económicas y políticas expuestas a presiones extranjeras.

En cuanto a la lucha contra la droga, el gobierno de Paz Estenssoro reorganizó todo el sistema en base a convenios y acuerdos con el Gobierno de los Estados Unidos, y con el apoyo de las Naciones Unidas. ${ }^{28}$ Volviendo de en una reunión de las Naciones Unidas en

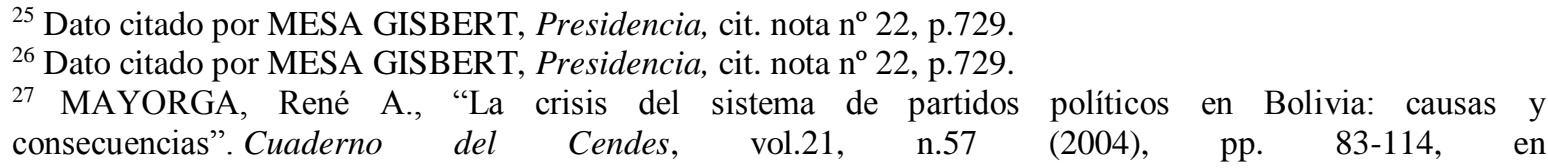
http://www.scielo.org.ve/scielo.php?script=sci arttext\&pid=S1012 25082004000300005\&lng=es\&nrm=iso [visitado el 24.02.2017], pp. 83-114. Por su lado, Mesa Gisbert explica las razones de la "democracia pactada" y quiere que se entienda la palabra "pacto" "como mérito y virtud y no como defecto o vicio la práctica de la negociación”. MESA GISBERT, Bolivia, cit. nota $\mathrm{n}^{\mathrm{o}} 17$, p. 46. Este análisis adopta la perspectiva de los estudios de "transitología" que celebran las virtudes de la tecnocracia, la reconciliación y los "consensos". Nos referimos a los estudios de ciencia política anglosajones iniciados con las transiciones portuguesa y española que pronto formaron una subdisciplina que experimentó un rápido crecimiento con el estudio de las transiciones latinoamericanas y más tarde de los países de Europa central y del este. Esta literatura fue producida por autores muy cercanos a los actores políticos, a menudo como consultores, con el objetivo de exportar la democracia liberal como el mejor sistema posible a partir de un aparato teórico marcado por el paradigma de la elección racional. Por ello la "transitología" ha sido duramente criticada por autores de ciencias sociales que destacan su carácter altamente normativo, prospectivo, lineal y tautológico. JOIGNANT Alfredo, "La politique des "transitologues": Luttes politiques, enjeux théoriques et disputes intellectuelles au cours de la transition chilienne à la démocratie", Politique et Sociétés, vol. 24, $\mathrm{n}^{\circ} 2-3$, (2005), pp. 33-59; SERRANO MORENO, Juan E., "La exhumación de 1979 en Murcia. Acción colectiva de familiares de fusilados republicanos durante la transición”, Ayer. Revista de Historia Contemporánea, 103/2016 (3), pp. 147-177.

${ }^{28}$ Véase la crítica de LASERNA, El fracaso, cit. nota n ${ }^{\circ} 17$, p. 70. 
Polit. crim. Vol. 13, № 25 (Julio 2018) Art. 8, pp. 264-321.

[http://www.politicacriminal.cl/Vol_13/n_25/Vol13N25A8.pdf]

Viena en 1987, ${ }^{29}$ Paz Estenssoro crea mediante decreto supremo la Fuerza Especial de Lucha contra el Narcotráfico (FELCN). Esta nueva unidad estaba integrada por miembros de las Fuerzas Armadas y de la Policía Nacional, destinada "única y exclusivamente a la lucha contra el narcotráfico". ${ }^{30}$

Desde la perspectiva internacional pareciera lógico involucrar a las Fuerzas Armadas en actividades de lucha contra las drogas. El presidente Ronald Reagan había declarado la guerra contra las drogas como objetivo de seguridad nacional en 1982. ${ }^{31}$ La criminóloga española-venezolana Rosa del Olmo explica que el objetivo central de esta guerra era la cocaína y con ello "los países productores de América Latina, la amenaza". ${ }^{32}$

Poco después de la creación de la fuerza especial, es aprobado la Ley de Régimen de Coca y Sustancias Controladas del 19 de julio 1988, conocida comúnmente como "Ley 1008".33 Se trata de una ley que combina en un solo texto disposiciones que regulan zonas para la producción, medidas de sustitución, erradicación de hojas de coca, a la par que contiene normas en materia penal, procesal y de prevención. Volveremos a esta normativa más adelante.

La aprobación de la Ley 1008 hizo que Bolivia apareciera como líder mundial en la "guerra" global contra el narcotráfico. Por ello, la conferencia de las Naciones Unidas que sirvió para la elaboración de la Convención contra el Tráfico Ilícito de Estupefacientes y Sustancias Sicotrópicas, celebrada 25 de noviembre al 20 de diciembre 1988), elige como su Presidente al canciller de Bolivia Guillermo Bedregal Gutiérrez. ${ }^{34}$ Laserna opina que esta elección fue considerada un reconocimiento a la "audacia legislativa" de Bolivia expresada en la Ley 1008. ${ }^{35}$ Terminada la conferencia, la Convención de las Naciones Unidas contra el Tráfico Ilícito de Estupefacientes y Sustancias Sicotrópicas (en adelante, La Convención de 1988) quedaba abierta a la firma.

\footnotetext{
${ }^{29}$ Reunión en la que se aprobó el Plan Amplio y multidisciplinario provisional de actividades futuras en materia de fiscalización de uso indebido de droga.

${ }^{30}$ Artículo 4 del Decreto Supremo 21666 de 24/VII/87. Texto disponible en QUIROGA, Coca, cit. nota no 10, pp. 95-99.

${ }^{31}$ El presidente estadounidense Richard Nixon acuñó en 1971 la expresión "guerra contra las drogas". Desde entonces se convirtieron en el "enemigo público número uno" de los Estados Unidos. El militar especialista en defensa estadounidense Michael H. Abbott destaca que Reagan firmó el 2 de abril 1986 el documento "National Security Decision Directive on Narcotics and National Security". Desde entonces el tema del narcotráfico debía que ser considerado en todas las decisiones relacionadas con la cooperación internacional y el rol del ejército en las actividades de lucha contra el narcotráfico tenía que ser reforzado. ABBOTT, Michael H., "The Army and the Drug War: Politics or National Security?", Parameters, (diciembre 1988), pp. 95-112, en: http://www.dtic.mil/dtic/tr/fulltext/u2/a528135.pdf [visitado el 07.05.2017], p. 99.

${ }^{32}$ Del Olmo destaca, que hasta 1975 la cocaína había ocupado solo el cuarto lugar en la lista de drogas a reprimir por parte del gobierno, pero que Reagan "la convirtió en la droga prioritaria". DEL OLMO, ¿Prohibir o domesticar?, cit. nota $\mathrm{n}^{\circ}$ 6, pp. 32 y s.

${ }_{33}$ Disponible en: https://www.unodc.org/pdf/convention_1988_es.pdf [visitado el 26.02.2017].

${ }^{34}$ Así lo indica el Acta Final de la conferencia de las Naciones Unidas para la aprobación de una Convención contra el Tráfico Ilícito de Estupefacientes y Sustancias Sicotrópicas, p. 4. En: https://www.incb.org/documents/PRECURSORS/1988_CONVENTION/1988Convention_S.pdf [visitado el 26.02.2017].

${ }^{35}$ LASERNA, El fracaso, cit. nota n ${ }^{\circ}$ 17, p. 76.
} 


\section{STIPPEL, Jörg; SERRANO, Juan. "La nacionalización} de la lucha contra el narcotráfico en Bolivia".

La Convención de 1988 fue criticada desde el primer momento. Rosa del Olmo (1992) percibe a la Convención de 1988 como "expresión máxima" de un "derecho penal máximo", tendencia consistente en el incremento de la represión para aumentar el poder intimidatorio de la norma penal. La autora advierte del peligro de la constitución de un derecho de las drogas de excepción que opera con crecientes restricciones a las garantías ciudadanas y en contradicción con los principios fundamentales del Derecho Penal y Procesal. ${ }^{36}$ También los investigadores holandeses Jelsma y Armenta critican la orientación represiva de la Convención de 1988, pues obliga a los países a usar el derecho penal para combatir todos los aspectos de la producción ilícita, posesión y tráfico de drogas, disponiendo medidas especiales contra el cultivo, la producción, la posesión y el tráfico ilícito de sustancias psicoactivas, y la desviación de precursores químicos. ${ }^{37}$ Los autores consideran necesario actuar en pos de la disminución de la violencia, pues las consecuencias de la Convención han sido, entre otras, el incremento casi mundial de la población encarcelada, el aumento de las violaciones a los derechos humanos y la criminalización de los consumidores. ${ }^{38}$

Si nos fijamos en el texto de la Convención de 1988 se confirma la orientación represiva. A diferencia de la Convención Única de 1961, ya no se teme por la salud física y moral de la humanidad, sino la Convención de 1988 pone en primer lugar la preocupación por "la magnitud y la tendencia creciente de la producción, la demanda y el tráfico ilícitos de estupefacientes y sustancias sicotrópicas". La respuesta prevista en la Convención de 1988 es la criminalización. Eso hace entendible la crítica de Laserna, cuando opina que, en la Convención de 1988, el argumento de la seguridad del Estado está por encima de la del individuo o la sociedad. ${ }^{39} \mathrm{La}$ orientación represiva queda a su vez en evidencia cuando la Convención pide que se impongan sanciones proporcionales a la gravedad de los delitos. La primera sanción que menciona es "la pena de prisión u otras formas de privación de libertad" y en segundo lugar habla de "sanciones pecuniarias y el decomiso". ${ }^{40} \mathrm{El}$ mensaje es claro: la cárcel debe resolver el problema de las drogas.

La Convención de 1988 abre además la puerta a injerencias en las políticas nacionales de todos los países firmantes al establecer que "la erradicación del tráfico ilícito es responsabilidad colectiva de todos los Estados". Lo que era en tema principalmente de la política criminal nacional ${ }^{41}$ pasa a ser es una responsabilidad internacional. Solo las acciones que surgen de esta responsabilidad debían ser coordinadas "en el marco de la

\footnotetext{
${ }^{36}$ DEL OLMO, ¿ Prohibir o domesticar?, cit. nota ${ }^{\circ}$ 6, p. 126.

${ }^{37}$ Véase artículo 3 de la Convención de 1988.

38 JELSMA, Martin; ARMENTA, Amira, Las convenciones de drogas de la ONU. Guía Básica, Octubre 2015, en: https://www.tni.org/files/publication-downloads/primer_unconventions_24102015-es.pdf [visitado el 07.05.2017], p. 11. Véase también JELSMA, Martin, "The development of international drug control: lessons learned and strategic challenges for the future", Working Paper Prepared for the First Meeting of the Commission Geneva, 24-25 January 2011, 2011, en: http://www.globalcommissionondrugs.org/wpcontent/themes/gcdp_v1/pdf/Global_Com_Martin_Jelsma.pdf [visitado el 07.05.2017].

${ }^{39}$ LASERNA, El fracaso, cit. nota n ${ }^{\circ} 17$, p. 76.

${ }^{40}$ Artículo 3 numeral 4 de la Convención de 1988.

${ }^{41}$ Véase artículo 35 de la Convención de 1961 que habla de ayuda mutua y cooperación en la lucha contra el tráfico ilícito. Pero no convierte esta lucha en una responsabilidad colectiva.
} 
cooperación internacional”. Aparentemente los redactores del texto de la Convención eran conscientes de un posible conflicto con el principio de soberanía garantizado en la Carta de las Naciones Unidas ${ }^{42}$, pues estipularon en el segundo artículo que las partes firmantes cumplirán sus obligaciones "de manera que concuerde con los principios de la igualdad soberana y de la integridad territorial de los Estados y de la no intervención en los asuntos internos de otros Estados". Prohíbe además que un Estado ejerza en el territorio de otro competencias o funciones que hayan sido reservadas exclusivamente a las autoridades de ese otro país por su derecho interno. ${ }^{43} \mathrm{~A}$ continuación veremos que ya la primera intervención públicamente visible de militares estadounidenses en la "guerra contra las drogas" en Bolivia - Blast Furnance - pone en duda el prescrito respeto a la soberanía y normativa nacional de los estados partes de la Convención.

\subsection{La Ley 1008 de 1988}

Podemos considerar la Ley 1008 como una expresión de loa que Del Olmo califica como “derecho penal máximo", o en la palabras de la investigadora boliviana Rose Marie Achá, una expresión del enfoque de "mano dura". ${ }^{44}$ En materia penal esta ley codifica conductas típicas asociadas al narcotráfico, ${ }^{45}$ como la posesión, fabricación, cultivo y tráfico de drogas. ${ }^{46}$ La ley contempla además tipos penales que suben las sanciones para delitos que podemos encontrar también en el Código Penal como asesinato, falsificación, encubrimiento y cohecho activo y pasivo. Cuando estas conductas se relacionan al narcotráfico, la Ley 1008 eleva los rangos de las penas aplicables. ${ }^{47}$ En total se contemplan 31 delitos distintos. Las normas que regulan la cooperación internacional estipulan además que el narcotráfico es un delito de "lesa humanidad". ${ }^{48}$

42 Art. 2 núm. 1 de la Carta de las Naciones Unidas.

${ }^{43}$ Articulo 2 numeral 2 y 3 de la Convención de 1988.

${ }^{44}$ ACHÁ, Rose M., Desproporcionalidad en el sistema penal antidrogas boliviano, Colectivo de Estudios de Drogas y Derecho, 2011, en: http://www.drogasyderecho.org/publicaciones/pub-bol/proporcionalidadbolivia.pdf [visitado el 25.02.2017], p. 54.

${ }^{45}$ Rosa del Olmo aclara que el concepto de narcotráfico requiere ser precisado. Indica que "este neologismo se ha construido con la raíz de la palabra narcótico y el sustantivo tráfico, pero narcótico significa adormecimiento, mientras que la cocaína produce todo lo contrario. " Igual señala, que en el lenguaje cotidiano narcotráfico "ha llegado a convertirse en un concepto abstracto y homogéneo, sinónimo de todo lo que tiene que ver con drogas ilegales". Es en ese último sentido que empleamos la palabra. DEL OLMO, ¿Prohibir o domesticar?, cit. nota $\mathrm{n}^{\circ}$ 6, p. 75.

${ }^{46}$ Eugenio Raúl Zaffaroni critica "la multiplicación de los verbos" que se dio en las legislaciones de drogas de Latinoamérica. Percibe que eso da paso a una "insólita extensión de la punibilidad", y ve en ello una clara característica del derecho penal autoritario. Zaffaroni explica que, para el derecho penal autoritario, la lesión al bien jurídico pasa al segundo plano y cobra importancia prioritaria detectar al "enemigo". Así que "la acción típica no tiene importancia por su conflictividad por afectar un bien jurídico, sino por ser síntoma revelador de la "enemistad". ZAFFARONI, Eugenio Raúl, "La legislación anti-droga latinoamericana: Sus componentes de Derecho Penal Autoritario”, en MORALES VITERI, Juan Pablo; PALADINES, Jorge Vicente (editores), Entre el control social y los derechos humanos-Los retos de la política y la legislación de drogas. Homenaje a Juan Bustos Ramírez, Quito: Ministerio de Justicia y Derechos Humanos, 2009, pp. 315 , p. 6 y siguiente.

47 Título III. de la Ley 1008 (artículo 46 al 79).

${ }^{48}$ Artículo 145 de la Ley 1008. 


\section{STIPPEL, Jörg; SERRANO, Juan. "La nacionalización de la lucha contra el narcotráfico en Bolivia".}

En materia procesal, ${ }^{49}$ la Ley 1008 creó juzgados especiales de sustancias controladas ${ }^{50}$ y fiscales de sustancias controladas. ${ }^{51}$ Las causas ante los juzgados especiales se podían tramitar en base a las diligencias de Policía Judicial levantadas por la Fuerza Especial de Lucha Contra el Narcotráfico. ${ }^{52}$ No era necesario seguir el procedimiento ordinario que contemplaba una fase de instrucción y sumario. Cuando los juzgados de sustancias controladas abrían una causa por cualquier delito contemplado en la Ley 1008, tenían que disponer la detención de los procesados. ${ }^{53}$ En la misma lógica, la ley estipula que en procesos sobre sustancias controladas, no procede el beneficio de la libertad provisional. ${ }^{54}$ Para terminar en la cárcel bastaba entonces el hecho de abrir una causa por la Ley 1008, aunque se tratara de la posesión de, por ejemplo, 2 gramos o 1.000 kilos de marihuana o cocaína. ${ }^{55}$ En estos casos se presumía la responsabilidad de la persona denunciada. Las cifras de detención preventiva analizadas en el último apartado del presente artículo dan cuenta de ello.

La Ley 1008, en la parte procesal, limitaba drásticamente el derecho a la defensa, restringiendo la presentación de excepciones prejudiciales (como un desafuero ${ }^{56}$ ) como cuestiones previas, ${ }^{57} \mathrm{y}$ aún peor estipulando que las diligencias de la policía "tienen carácter de prueba preconstituida". ${ }^{58}$ Es decir la jueza o el juez tenían que aceptar como prueba incuestionable los informes de la policía donde constaba "con clara especificación la identificación del o de los implicados" y el "día, lugar y circunstancias".59 Laserna indica que en base a estas normas, incluso cuando los policías no ratificaban sus informes, o cuando estos estaban incompletos o deficientes, las juezas y los jueces tenían que creer en sus contenidos ${ }^{60}$. Vemos que uno de los aspectos más evidentes donde la Ley 1008 vulnera el ordenamiento constitucional es la vulneración del principio de presunción de inocencia y de defensa previstos en la Constitución vigente en ese momento. ${ }^{61}$

Es entendible que la Ley 1008 ha sido criticada por diferentes sectores de la sociedad boliviana y desde diferentes perspectivas. En 2007, la "Estrategia de lucha contra el narcotráfico y revalorización de la hoja de coca" publicada por el Consejo Nacional contra

${ }^{49}$ Título IV. de la Ley 1008.

${ }^{50}$ Art. 83 de la ley 1008.

${ }^{51}$ Art. 92 de la Ley 1008.

${ }^{52}$ Art. 86 de la Ley 1008.

${ }_{53}^{53}$ Así lo disponía el art. 103 letra a de la ley 1008.

${ }^{54}$ Artículo 109 de la Ley 1008. La libertad provisional correspondía en los demás delitos cuando, entre otros, cuando la pena prevista para el delito imputado no excedía los cuatro años. Véase artículo 196 al 207 del antiguo Código de Procedimiento Penal (Ley 10426 del 26.08. 1972).

55 Achá analiza casos de consumidores detenidos en las cárceles bolivianas por la Ley 1008. ACHÁ, Desproporcionalidad, cit. nota $\mathrm{n}^{\circ} 44$, p. 5.

${ }^{56}$ Véase artículos 174 y siguientes del antiguo Código de Procedimiento Penal (Ley 10426 del 26.08. 1972).

${ }^{57}$ Articulo 108 Ley 1008.

${ }^{58}$ Artículo 116 oración 3 de la Ley 1008.

${ }^{59}$ Artículo 99 de la Ley 1008.

${ }^{60}$ LASERNA, El fracaso, cit. nota n ${ }^{\circ} 17$, p. 74.

${ }^{61}$ La Constitución Política de Bolivia de 1967 con las reformas de 1994 establecía en su art. 16.- I: "Se presume la inocencia del encausado mientras no se pruebe su culpabilidad. II. El derecho de defensa de la persona en juicio es inviolable". 
el Tráfico Ilícito de Drogas (en adelante CONALTID) ${ }^{62}$ criticó que la aprobación de la Ley 1008 había respondido principalmente a exigencias externas "sin ofrecer soluciones estructurales a la problemática de las drogas en Bolivia; más al contrario contribuyó al avasallamiento de la historia, identidad, cultura, tradiciones, y daño al medio ambiente en el país". ${ }^{63}$ En el mismo sentido, el especialista en políticas antidrogas Diego Giacoman afirma que la elaboración de la ley había estado a cargo de funcionarios del Gobierno de los Estados Unidos. ${ }^{64}$ Incluso el historiador y posterior presidente de Bolivia, Carlos Mesa Gisbert considera la Ley 1008 un instrumento que pasaba por encima de la constitución del país con tribunales especiales y fiscales de narcóticos casi omnipotentes. ${ }^{65}$

En respuestas a las múltiples críticas, el nuevo Código de Procedimiento Penal promulgado en 1999 derogó toda el apartado procesal de la Ley 1008. La reciente Ley de Coca adoptada en 2017 reemplaza también el articulado referido a la producción y erradicación de la hoja de coca. Quedan por tanto vigentes en la actualidad todas las normas penales y las que regulan la cooperación internacional contenidas en la Ley 1008.

\subsection{La reaparición de la "doctrina de seguridad nacional"}

La política de droga estaba acompañada de una camuflada reaparición de la "doctrina de seguridad nacional" proveniente de la dictadura. La implementación de esta política tuvo lugar en un contexto de creciente convulsión social generada por las políticas neoliberales implementadas desde principios de los años 1990 con el primer gobierno de Gonzalo Sánchez de Lozada (1993-1997). El presidente bautizó su plan de gobierno como "Plan de Todos" que en la práctica inspirado en las recetas de la cooperación internacional, ampliamente festejado por sus representantes. ${ }^{66}$ Parte central de este programa de cambio fue un proceso llamado de "capitalización" consistente en la privatización del $50 \%$ del patrimonio de empresas estatales. Entre 1995 y 1996 el gobierno “capitalizó” de esta

${ }^{62}$ El Consejo Nacional de Lucha contra el Tráfico Ilícito de Drogas. Véase su página en: http://www.conaltid.gob.bo/web/index.html

${ }^{63}$ CONALTID, Estrategia de lucha contra el narcotráfico y revalorización de la hoja de coca 2007-2010, La Paz: CONALTID, 2007, en http://www.embajadadebolivia.com.ar/m documentos/imgdocumentos/05coca.pdf [visitado el 24.02.2017], p. 18.

${ }^{64}$ GIACOMAN A., Diego, "Lucha contra el narcotráfico y situación carcelaria en Bolivia", WOLA, mayo 2010, en https://www.wola.org/sites/default/files/downloadable/Drug\%20Policy/2011/63/sistemas \%20sobrecargados \%20-\%20completo\%20bolivia.pdf [visitado el 24.02.2017], p. 8.

${ }^{65}$ MESA GISBERT, Historia, cit. nota $\mathrm{n}^{\circ} 21$, p. 750.

${ }^{66}$ En palabras del FMI: "The basic strategy for institutional reform in the authorities' 1994-98 program was exceptionally coherent - in many ways, it reads as if it had been designed in response to the literature on institutional weaknesses in Bolivia that was written several years later. Not only did the program call for the reform of critical institutions-including the judiciary, the civil service, and the central bank-but it emphasized the need for widening political participation and redistributing resources to the disenfranchised." INTERNATIONAL MONETARY FUND, Bolivia. Ex-Post Assessment of Longer-Term Program Engagement, Country Report no5/139 (abril 2005), p. 29, en https://www.imf.org/external/pubs/ft/scr/2005/cr05139.pdf [visitado el 24.02.2017]. 


\section{STIPPEL, Jörg; SERRANO, Juan. "La nacionalización de la lucha contra el narcotráfico en Bolivia".}

manera a las cinco empresas estatales más grandes. ${ }^{67} \mathrm{~A}$ su vez se implementaron reformas estructurales al sistema de justicia. Mediante el cambio constitucional de agosto 1994, se crea el Tribunal Constitucional, el Consejo de la Judicatura y el Defensor del Pueblo. Además se elaboran proyectos de ley para reformar el código penal y procesal penal, los que fueron aprobados en el siguiente gobierno de Banzer-Quiroga (1997-2002). ${ }^{68}$

Durante el gobierno del ex-dictador, tomó creciente importancia en la agenda política el tema de la "seguridad ciudadana". 69 Considerando a los actores implicados y una conceptualización meramente represiva, esta política recuerda mucho a la "doctrina de seguridad nacional" de la dictadura. El jurista boliviano Arturo Yánez describe que los orígenes de la nueva política se sitúan en la década de los años 1960 "en los que predominó una concepción sobre la seguridad de contornos netamente militaristas centrados en la derrota del comunismo y en el mantenimiento del orden público mediante la violencia institucional que el propio estado mediante sus agentes aplicó a sus ciudadanos ${ }^{70}$ ". El autor explica que "la doctrina de la seguridad nacional institucionalizó el uso de la violencia contra los ciudadanos por parte de las fuerzas armadas y policiales e incluso mediante grupos especialmente creados para el efecto". ${ }^{71}$

Durante el gobierno de Banzer-Quiroga, el "Plan Ciudadela" de 2000 habilita la intervención de las Fuerzas Armadas en tareas de prevención de la delincuencia en apoyo de la policía nacional. En ese momento comienza a generalizarse la militarización de la política criminal. Lo que antes solo tenía relevancia en materia de lucha contra el narcotráfico, ahora se extiende a toda la política criminal del gobierno. Esto provocó una dependencia del sendero en el Estado como lo muestra el hecho que Evo Morales mantuviera la decisión de involucrar a las fuerzas armadas en actividades de seguridad interna. En este sentido, el art. 1 del Decreto Supremo 354 del 6 de noviembre de 2009 dispone expresamente que "las Fuerzas Armadas del Estado, apoyen en forma coordinada

67 Las empresas Yacimientos petrolíferos Fiscales Bolivianos (YPFB), Empresa Nacional de Telecomunicaciones (ENTEL), Empresa Nacional de Electricidad (ENFE), Lloyd Aero boliviano (LAB) y Empresa Nacional de Ferrocarriles (ENFE). MESA GISBERT, Historia, cit. $\mathrm{n}^{\text {o }}$ 21, p. 765.

${ }^{68}$ Lazarte opina que el gobierno de Banzer-Quiroga "aparentemente ya nada podía hacer sino seguir la ruta trazada". No obstante "y para diferenciarse del gobierno anterior que imponía y no consultaba, como efectivamente había hecho con sus reformas, inventó el Diálogo Nacional". LAZARTE, Jorge, Hacia un país moderno y democrático. La Asamblea Constituyente: un nuevo comienzo, La Paz: Plural Editores, 2006, p. 29.

${ }^{69}$ La definición o re-definición del término de seguridad ciudadana es en sí un tema político, o en las palabras del académico chileno Patricio Tudela, "un concepto en construcción". Tudela explica que el concepto emerge en la década de los ochenta, particularmente en los noventa, y que transitó desde "una forma y visión reduccionista de la seguridad, que la subordina únicamente a la respuesta policial y legal por parte del Estado y sus órganos (donde el referente más actual son, por ejemplo, riesgos globales como el terrorismo y el narcotráfico, entre otros flagelos de la vida moderna), hacia un enfoque más amplio e integral vinculado a la necesidad de abordar, controlar y superar los riesgos "cotidianos" que afectan a las personas". TUDELA, Patricio, Conceptos y orientaciones para políticas de seguridad ciudadana, Santiago: CIDEPOL, p. 6, 2005, en: http://www.investigaciones.cl/cidepol/biblioteca/conceptosyorientaciones.pdf [visitado el 25.02.2017].

70 YANEZ, Arturo, "Ley del sistema nacional de seguridad ciudadana. ¿Un instrumento eficaz para combatir la delincuencia en el marco del estado de derecho?", Foro Sucrense. Revista del I. Colegio de Abogados de Chuquisaca, n¹2 (marzo 2004), pp. 6-9, en http://www.arturoyanezcortes.com/pdf/artrev008.pdf [visitado el 25.02.2017].

71 YANEZ, "Ley", cit. nota no 70, pp. 6-9. 
las acciones de la Policía Boliviana en la prevención de la delincuencia y preservación de la seguridad ciudadana". Lo interesante es que se restringía inicialmente el ámbito de aplicación de esta norma a la ciudad de Santa Cruz de la Sierra del departamento de Santa Cruz marcado por tensiones secesionistas.

Lo que cambió en la conceptualización inicial de la seguridad ciudadana en el gobierno de Banzer-Quiroga en comparación con la "doctrina de seguridad nacional" fue la identidad del enemigo. Ya no es el comunismo, sino el ciudadano que se opone al orden establecido y el "delincuente". Para este enfoque de política criminal la violencia no es excepcional, sino fundacional. El orden público no se mantiene en base a un contrato social o la legitimidad de la ley, sino en base a la violencia. ${ }^{72}$ La historia reciente muestra que esa receta represiva no funcionó en el caso boliviano. Cuando las protestas sociales se agudizaron y fueron reprimidas de manera sangrienta por el segundo gobierno de Sánchez de Lozada (20022003), al presidente no le quedó otra opción que huir del país.

\subsection{La militarización de la política criminal}

De esta manera, la reaparición de la doctrina de la seguridad nacional fue a la mano con la paulatina militarización de la política antidroga. En agosto de 1984 se iniciaron las operaciones militares con la movilización de quinientos efectivos del ejército nacional para destruir laboratorios de cocaína y arrestar narcotraficant. ${ }^{73}$ Poco después se internacionalizó esta estrategia. Tres meses después de que Reagan hubiera declarado la "guerra contra las drogas" se inicia la intervención de militares estadounidenses en Bolivia bajo el nombre operativo "Blast Furnace" 74 el 15 de julio 1986. El militar norteamericano Michael Abbott relata que fue el propio vicepresidente Bush quien impulso que varios departamentos y agencias se involucraran en el operativo. La acción militar contaba con seis helicópteros Black Hawk que llegaron desde Panamá y 170 oficiales del ejército - Task Force Janus. Su encargo formal fue transportar a la policía boliviana para que pueda realizar las operaciones de erradicación de cultivos de coca. Abbott relata que todos los militares habían estado bajo el mando directo del embajador de Estados Unidos en Bolivia. ${ }^{75}$

La militarización se profundizó en los siguientes años y gobiernos. El presidente Jaime Paz

\footnotetext{
${ }^{72}$ Es en el mismo sentido que el criminólogo y político chileno, Juan Bustos Ramírez, explica que: "la doctrina de la Seguridad Nacional implica siempre la imposición de objetivos de otro, de la salvación de la civilización cristiano occidental y, dentro de ello, entonces de los objetivos del gobierno de Estados Unidos. Tal doctrina implica que el ciudadano pasa a ser un enemigo, el enemigo interno y, por tanto, hay que aplicarle los principios de la guerra, esto es, vencerlo, eliminarlo, sin consideración a los principios democráticos que rigen el sistema". BUSTOS RAMÍREZ, Juan, Coca-Cocaína-Política Criminal de la Droga, Editorial Jurídica ConoSur, Santiago de Chile, 1995, p. 120.

${ }^{73}$ SALAZAR, Fernando, "El Plan Dignidad y el militarismo en Bolivia. El caso del Trópico de Cochabamba", Buenos Aires: CLACSO, 2003, p. 95, en: http://biblioteca.clacso.edu.ar/clacso/formacionvirtual/20100724065836/11salazar.pdf [visitado el 25.02.2017].

${ }^{74}$ Acerca de algunos protagonistas de ese operativo, véase el artículo periodístico de GARCÍA M., Wilson, "El represor de los cocaleros vuelve a Bolivia", Voltairenet.org, 1 octubre 2002, en: http://www.voltairenet.org/article120332.html [visitado el 25.02.2017].

${ }^{75}$ ABBOTT, "The Army", cit. nota no 31, pp. 101 y s.
} 


\section{STIPPEL, Jörg; SERRANO, Juan. "La nacionalización} de la lucha contra el narcotráfico en Bolivia".

Zamora (1989-1993) estrechó los lazos diplomáticos y militares con el gabinete de George Bush. La Declaración de Cartagena de 1990, firmada por los jefes de Estado Jaime Paz Zamora, George Bush, Virgilio Barco Vargas (Colombia) y Alan García (Perú) contempla la intervención de las Fuerzas Armadas en la lucha contra el narcotráfico. En primer lugar, reconoce que "la represión del tráfico de drogas ilícitas es una cuestión, en su esencia de carácter policial". No obstante, arguye que "ante su magnitud y las diferentes facetas que presenta (...) las Fuerzas Armadas de cada uno de los países (...) también pueden tomar parte". Pero no son sólo las Fuerzas Armadas de cada país en su país pues el convenio permite que "las partes podrán establecer los debidos entendimientos bilaterales y multilaterales de cooperación, de conformidad con sus intereses, necesidades y prelaciones". ${ }^{76}$ Estas previsiones actualizan lo que la Convención de 1988 reconoce como "cooperación internacional".

De esta relación entre los gobiernos nace el Anexo III de la Ley 1008 "sobre la necesidad de militarizar la lucha contra el narcotráfico". Una legislación que fue "ocultada al país" en palabras del historiador Mesa Gisbert nombrado presidente de la República en 2003 y por tanto un testigo privilegiado de estos hechos. ${ }^{77}$ En efecto, desconocemos tanto la fecha real de adopción del anexo como su contenido. Se trata de una "norma secreta" que vulnera unos de los principios generales más elementales del Estado de derecho consistente en la necesaria publicación de una norma para su entrada en vigor. Este ocultamiento muestra una clara voluntad del gobierno de evitar el debate y cuestionamiento público de la ley criticable por la pérdida de soberanía que implicaba. El siguiente gobierno presidido por Gonzalo Sánchez de Lozada (1994-1997) ideó el plan "opción cero" pensado para eliminar la totalidad de cultivos de coca utilizados para el narcotráfico para el que se buscó el respaldo de la comunidad financiera internacional. ${ }^{78}$

En respuesta al plan, los campesinos y el entonces líder de los cocaleros Evo Morales organizaron la "Marcha por la Vida, la Coca y la Soberanía Nacional" en $1994 .{ }^{79}$ Los activistas exigían la salida de militares y policías del Chapare, la despenalización de la coca, la modificación de la Ley 1008 y el retiro inmediato de USAID. ${ }^{80}$ Esta marcha marca el inicio de un ciclo de protestas ascendente en Bolivia con la consecuente radicalización de los discursos de los movimientos sociales. Evo Morales afirmó por aquel entonces a los medios de comunicación que "los compañeros productores de coca hemos decidido,

\footnotetext{
${ }^{76}$ Punto B.3. de la Declaración de Cartagena de 1990.

${ }^{77}$ Sorprende que Mesa Gisbert afirme que ese anexo "nunca se aplicó". MESA GISBERT, Historia, cit. nota $\mathrm{n}^{\mathrm{o}} 21, \mathrm{p} .758$.

${ }^{78}$ Véase la noticia de Inter Press Services. Agencia de Noticias "Opción cero, el plan Marshall del gobierno", 9 de noviembre 1994, en: http://www.ipsnoticias.net/1994/11/drogasbolivia-opcion-cero-el-plan-marshall-delgobierno/ [visitado el 25.02.2017].

${ }^{79}$ Stefanoni describe como tras la detención de Morales, la marcha llegó a La Paz por "caminos secretos" y con el apoyo de las poblaciones campesinas, coreando consignas como "fusil, metralla, la marcha no se calla" o "con bombas, con gas, la marcha está en La Paz". STEFANONI, Pablo, "El nacionalismo indígena como identidad política: La emergencia del MAS-IPSP (1995-2003)", Informe final del concurso: Movimientos sociales y nuevos conflictos en América Latina y el Caribe, Programa Regional de Becas CLACSO (2002), p. 21, en: http://bibliotecavirtual.clacso.org.ar/ar/libros/becas/2002/mov/stefanoni.pdf [visitado el 25.02.2017].

80 Véase la noticia de El Diario "La hoja intocable", 21 de junio 2015, en: http://www.eldiario.net/noticias/2015/2015 06/nt150621/politica.php?n=44\&-la-hoja-intocable [visitado el 25.02.2017].
} 
Polit. crim. Vol. 13, № 25 (Julio 2018) Art. 8, pp. 264-321.

[http://www.politicacriminal.cl/Vol_13/n_25/Vol13N25A8.pdf]

definitivamente, si el Gobierno no cambia de política respecto a la forma de erradicación de los cultivos de coca, pasar de la resistencia a la ofensiva y decir qué vamos a enfrentar, hacer cualquier cosa para defender la coca" ${ }^{81}$ En ese ambiente de conflicto, la llegada de la marcha a La Paz el 19 de septiembre 1994 representó un duro revés para el gobierno. ${ }^{82}$ Esta acción representa un momento fundacional para el imaginario del MAS como lo muestra la conmemoración oficial del vigésimo aniversario de la marcha en 2014 en el que participó Evo Morales junto a antiguos marchistas. ${ }^{83}$

El proceso de militarización de la política criminal alcanzó su punto álgido durante la presidencia del exdictador Hugo Bánzer Suárez de 1997 a 2002. El nombre con que se bautizó su nueva estrategia de erradicación fue "Plan Dignidad", 84 ampliamente celebrado por la comunidad internacional. La Comisión Interamericana para el Control del Abuso de Drogas (en adelante CICAD) reconoció en 1999 los esfuerzos para la eliminación de cultivos ilícitos recomendando "continuar con los esfuerzos que permitan a Bolivia cumplir su objetivo de salir del circuito coca-cocaína para el año 2002 y establecer un mecanismo que permita el sostenimiento de esos logros contando con el esfuerzo nacional y la cooperación internacional ${ }^{85}$ ". La embajada de Estados Unidos prometió para ello asistencia y recursos según los documentos desclasificados más tarde por el Departamento de Estado, editados y publicados por la Vicepresidencia del gobierno boliviano. ${ }^{86}$

En la misma línea, la Junta International de Fiscalización de Estupefacientes de las Naciones Unidas (en adelante JIFE), declaró en 1999 que "el Gobierno de Bolivia merece el reconocimiento de la comunidad internacional por la voluntad política de que ha hecho gala y por los recursos financieros técnicos y humanos que ha invertido en sus actividades de erradicación del arbusto de coca" ${ }^{87}$ No obstante señala que las leyes del mercado son más fuertes pues "los importantes logros en materia de reducción del cultivo ilícito del

${ }^{81}$ El Diario "La hoja", cit. nota no 80.

82 STEFANONI, "El nacionalismo", cit. nota no 79, p. 19 y s.; PINTO OCAMPO, María T., "Entre la represión y la concertación: los cocaleros en el Chapare y en el Putumayo", Informe final del concurso: Movimientos sociales y nuevos conflictos en América Latina y el Caribe, Programa Regional de Becas CLACSO (2004), en: http://biblioteca.clacso.edu.ar/clacso/becas/20110127090256/pinto.pdf [visitado el 25.02.2017], p. 13 y s.

${ }^{83}$ Véase el comunicado oficial del gobierno "Morales rinde homenaje a 20 años de la marcha "Por la Vida y la Soberanía Nacional" protagonizada por mujeres", Ministerio de la Comunicación del Estado Plurinacional de Bolivia, 18 de noviembre 2014, en: http://www.comunicacion.gob.bo/?q=20151218/20167 [visitado el 25.02.2017].

${ }^{84}$ SALAZAR, "El Plan", cit. nota n 73.

85 CICAD; OEA, Bolivia. Evaluación del Progreso de Control de Drogas. Mecanismo de Evaluación Multilateral 1999-2000, 1999, en: http://www.cicad.oas.org/mem/reports/1/Full_Eval/Bolivia_spa.rev2.pdf [visitado el 25.02.2017], pp. 5 y 9.

86 VICEPRESIDENCIA DEL ESTADO PLURINACIONAL DE BOLIVIA, Injerencia de los Estados Unidos en Bolivia. Documentos desclasificados por el Departamento de Estado de los Estados Unidos, agosto 2009, en: https://www.vicepresidencia.gob.bo/IMG/pdf/desclasificados.pdf [visitado el 25.02.2017], p. 8.

87 JUNTA INTERNACIONAL DE FISCALIZACIÓN DE ESTUPEFACIENTES, Informe de la Junta Internacional de Fiscalización de Estupefacientes correspondiente a 1999 (E/INCB/1999/1), 1999, en: https://www.incb.org/documents/Publications/AnnualReports/AR1999/AR_1999_S.pdf [visitado el 25.02.2017], p. 46, $\$ 290$. 


\section{STIPPEL, Jörg; SERRANO, Juan. "La nacionalización de la lucha contra el narcotráfico en Bolivia".}

arbusto de coca en Bolivia y en Perú realizados durante los últimos dos años parecen haber sido contrarrestados por el aumento de la producción de hoja de coca en Colombia". ${ }^{88}$ En 2002, la CICAD recomienda que Bolivia continúe con las actividades de erradicación concluyendo que "Bolivia ha venido demostrando en los últimos años un auténtico deseo de poner término al problema de las drogas en el país, haciendo esfuerzos a un alto costo económico y social, a pesar de sus limitados recursos". ${ }^{89}$

El mencionado Plan Dignidad contó con un presupuesto de 900 millones de dólares estadounidenses destinados a la creación de las Fuerza de Tarea Conjunta (en adelante FTC) formada por el ejército, la fuerza aérea, la armada, los cuerpos de élite de la policía Unidad Móvil para el Patrullaje Rural "Leopardos" (UMOPRA), policía ecológica y mercenarios denominados "Fuerza Expedicionaria". ${ }^{90}$ La politóloga María Teresa Pinto Ocampo resalta el rol protagónico de los militares en la erradicación de los cultivos de coca indicando que en la FTC participaron cerca de 500 policías y 1.500 militares. $^{91}$

El impacto de la militarización de la política criminal fue sangriento. El periodista Alex Contreras Baspineiro ${ }^{92}$ señala que desde la implementación de la Ley 1008 en 1988 "fallecieron más de 115 personas, la mayoría productores de coca y los menos uniformados. Ninguno de los culpables de los asesinatos fue esclarecido, ni los responsables sentenciados. Existe total impunidad". ${ }^{93}$ Unos años más tarde, en 2007, el CONALTID concluye que "se puede evidenciar que la etapa en la que se intensificó la erradicación de cultivos de hoja de coca, coincidió con la etapa de mayor represión y violación de los derechos humanos". 94

Por el otro lado podemos constatar que el proceso de militarización acarreó efectos no deseados por sus autores al favorecer el empoderamiento de la sociedad civil boliviana.

${ }^{88}$ JUNTA INTERNACIONAL DE FISCALIZACIÓN DE ESTUPEFACIENTES, Informe, cit. nota $\mathrm{n}^{\circ}$ 87, p. $45, \oint 282$.

89 CICAD, Bolivia. Evaluación del Progreso de Control de Drogas 2000-2001, 2001, en: http://www.cicad.oas.org/mem/reports/2/Full_Eval/Bolivia\%20-\%20esp.pdf [visitado el 25.02.2017], pp. 5 y 8.

${ }^{90}$ El sociólogo boliviano Fernando Salazar considera que para la FTC la organización sindical campesina de productores del Chapare era "mala y delictiva, siendo un fin complementario al de la erradicación el acabar con el sindicalismo (...). De ello se desprende la actitud inhumana de represión que se tiene contra todo dirigente campesino de los productores de coca, ya que se les ve como a los culpables del narcotráfico y la situación de violencia en contra del país". Estas medidas militares representan por tanto una continuidad de la represión política de los tiempos de la dictadura. Las organizaciones sindicales reemplazaron al comunismo como enemigo legitimador de la violencia estatal. SALAZAR, "El Plan”, cit. nota n ${ }^{\circ} 73$, pp. 96-98.

${ }^{91}$ PINTO OCAMPO, "Entre la represión", cit. nota n ${ }^{\circ} 82$, p. 14.

${ }^{92}$ Contreras se desempeñó más tarda como vocero del primer gobierno de Evo Morales. Véase el artículo periodístico La Razón, "Álex Contreras Baspineiro: De vuelta al periodismo", 7 de julio 2013, en: http://www.la-razon.com/index.php?_url=/suplementos/animal_politico/Alex-Contreras-Baspineiro-vueltaperiodismo_0_1864613561.html [visitado el 25.02.2017].

${ }_{93}$ Véase el artículo periodístico de América Latina en Movimiento, "Un muerto y 19 heridos en el Trópico de Cochabamba", 29 de septiembre 2004, en: http://www.alainet.org/active/6836 [visitado el 25.02.2017].

${ }^{94}$ Sobre estos hechos, la CONALTID contempla cifras que llegan sólo hasta el año 2002: "según datos de la Asamblea de Derechos Humanos, entre 1998 y 2002, en la zona del Trópico de Cochabamba la represión ejercida ocasionó: 33 cocaleros muertos (huérfanos y familias desamparadas), 567 heridos, 693 detenidos, 27 bajas policiales y militares, y 135 policías y militares heridos". CONALTID, Estrategia, cit. nota nº 63, p. 20. 
Polit. crim. Vol. 13, № 25 (Julio 2018) Art. 8, pp. 264-321.

[http://www.politicacriminal.cl/Vol_13/n_25/Vol13N25A8.pdf]

Como lo indica la misma estrategia del CONALTID: "La resistencia a esta política llevó al movimiento cocalero a organizarse social y políticamente impulsando procesos de cambio estructurales en el país". ${ }^{95}$ En ese contexto, el movimiento sindical decidió que Evo Morales postulara como diputado al congreso boliviano siendo elegido en 1997.

Otro impacto indirecto fue la creciente indignación de grandes partes de la clase media y urbana boliviana con lo que se percibía como intromisión extranjera en los asuntos internos del país. ${ }^{96} \mathrm{El}$ entonces embajador de Estados Unidos Manuel Rocha, cuatro días antes de las elecciones presidenciales del 2002 advirtió que "el electorado boliviano debe considerar las consecuencias de escoger líderes de alguna manera ligados al narcotráfico y el terrorismo". ${ }^{97}$ El conflicto social provocado por la militarización de la política antidrogas produjo entonces algo impensable por las activistas e intelectuales de izquierdas unos años antes: el alineamiento transversal de la clase media con las organizaciones campesinas indígenas en pos del cambio político. ${ }^{98}$

Por último y desde la perspectiva militar, podemos ver que la primera acción de cooperación militar internacional en la guerra contra las drogas (Blast Furnace) fue un fracaso. Abbott describe que un efecto del operativo había sido el desplazamiento del narcotráfico, pues estima que unos 800 narcotraficantes se fugaron de la zona. No obstante eso había sido un impacto temporal, porque finalizado el operativo, volvieron. ${ }^{99} \mathrm{La}$ experiencia boliviana de militarización de la política criminal es importante, pues muestra que estrategias militares no pueden reemplazar investigaciones criminales. ${ }^{100}$

${ }^{95}$ CONALTID, Estrategia, cit. nota n ${ }^{\circ} 63$, p. 20.

${ }^{96}$ Gisbert critica que cuando investía el cargo de vicepresidente (2002-2003) de Sánchez de Lozada, su gestión se "vio asediada por la cooperación internacional”. Afirma que "ésta se tomó atribuciones más allá del respeto al Estado boliviano, aprovechando la difícil situación económica de éste, especialmente en el periodo 1999-2006". MESA GISBERT, Bolivia, cit. nota n 17, p. 100.

97 VICEPRESIDENCIA DEL ESTADO PLURINACIONAL DE BOLIVIA, Injerencia de los Estados Unidos en Bolivia. Documentos desclasificados por el Departamento de Estado de los Estados Unidos, agosto 2009, en: https://www.vicepresidencia.gob.bo/IMG/pdf/desclasificados.pdf [visitado el 25.02.2017], p. 19.

${ }^{98}$ Este fenómeno ha fascinado a analistas extranjeros inspirando estrategias partidarias contrahegemónicas en sistemas democráticos neoliberales marcados por la pérdida de soberanía y el empobrecimiento de la clase media, de la mano de actores como Iñigo Errejón en España. ERREJÓN, Iñigo, "Política, conflicto y populismo (I)", Viento Sur, n¹14 (enero 2011), pp. 75-84; "Política, conflicto y populismo (II)", Viento Sur, n¹15 (marzo 2011), pp. 105-114; "Política, conflicto y populismo (III). También en Europa: posibilidades populistas en la política europea y española", Viento Sur, no115 (marzo 2011), pp. 105-114; "El 15M como discurso contrahegemónico", Encrucijadas Revista Crítica de Ciencias Sociales, n² (2011), pp. 120-145; ERREJÓN, Iñigo; MOUFFE, Chantal, Construir pueblo. Hegemonía y radicalización de la democracia, Madrid: Icaria, 2015; SOTO, David, "Podemos o la irrupción plebeya: nota bibliográfica", Revista Sociología Histórica, no5 (2015), pp. 547-563.

${ }^{99}$ Abbott sostiene que el logro principal había sido el de comprobar la intención y el compromiso de Estados Unidos de hacer algo y de cooperar activamente con la policía boliviana. ABBOTT, "The Army", cit. nota no 34, pp. 102 y s. Mesa Gisbert llega a la misma conclusión cuando afirma en relación a la política de "coca cero" impulsada por Banzer que la reducción de cultivos se revirtió "en algo más de un lustro". MESA GISBERT, Presidencia, cit. nota nº 22, p. 191.

${ }^{100}$ Abbott indica además que el operativo había tenido un alto costo político para las autoridades bolivianas: "Blast Furnace was not without political cost to the government of Bolivia. President Victor Paz Estenssoro 
STIPPEL, Jörg; SERRANO, Juan. "La nacionalización

de la lucha contra el narcotráfico en Bolivia".

\section{Hacia una política de descriminalización}

\subsection{Del "cato de coca" a la nueva institucionalidad antinarcótica}

Como respuesta a la militarización de la lucha contra el narcotráfico y de la erradicación de los cultivos de hoja de coca surge la movilización para el "cato de la coca". Una lucha cuyos resultados terminaron por traducirse en la elección de Evo Morales como presidente el 18 de diciembre de 2005 y protección de la hoja de coca consagrada en el artículo 384 la Constitución del Estado Plurinacional de Bolivia promulgada el 9 de febrero 2009. ${ }^{101}$

El cambio de dirección de la política antidrogas comenzó con el gobierno de Carlos Mesa Gisbert (2003-2005) cuando ese concluye con los sindicatos de cultivadores el Convenio de Chapare en 2004. ${ }^{102}$ Un acuerdo que autorizaba el cultivo de un cato - unos 1.600 metros cuadrados - de coca por familia sindicalizada dentro de los territorios de las seis federaciones campesinas de esa región. ${ }^{103}$ Además se toleraron 18 mercados primarios de acopio y venta permitiendo su comercialización al mercado nacional de la cosecha ${ }^{104}$. Fue Evo Morales el dirigente de los cocaleros quien firmó el convenio por el que se llega a un acuerdo con el gobierno. ${ }^{105} \mathrm{El}$ otro actor, el presidente Mesa Gisbert, relata en sus memorias, que eso había sido la primera vez que el gobierno boliviano tomó una decisión de esa naturaleza sin consultas previas con la Embajada de Estados Unidos. ${ }^{106}$

El impacto social del convenio fue positivo. Como señala un informe del think tank estadounidense Transnational Institute "la obtención del cato representó paz y estabilidad en el Chapare, después de años de enfrentamientos y militarización de la zona, y un alto

received heavy criticism within his own country for having allowed foreign military forces to impose on sovereign Bolivian soil and to conduct "military operations" against Bolivian citizens. Other criticism came from the Organization of American States, Cuba, and other Latin countries. The combined pressure on the Bolivian President was so intense that there was serious concern in the United States that the government of Bolivia might topple as a result.", ABBOTT, “The Army”, cit. nota n 31, p. 104.

${ }^{101}$ El artículo 384 de la Constitución del Estado Plurinacional de Bolivia dispone que: "El Estado protege a la coca originaria y ancestral como patrimonio cultural, recurso natural renovable de la biodiversidad de Bolivia, y como factor de cohesión social; en su estado natural no es estupefaciente. La revalorización, producción, comercialización e industrialización se regirá mediante la ley".

102 Mesa Gisbert describe la estrategia de negociaciones de Evo Morales de la siguiente manera: "Era, como siempre, la lógica de negociar y regatear, colocándose en posición de ataque. Su planteamiento era claro, nos dijo que garantizaba la pacificación total si esta vez lográbamos (...) la autorización de medio cato de coca por familia y la aceptación de hasta un máximo de 3.500 hectáreas en la región". Sorprende que Mesa Gisbert sólo haga referencia a medio cato, ya que Morales estaba pidiendo desde el año 2000 un cato por familia. MESA GISBERT, Presidencia, cit. nota $\mathrm{n}^{\circ} 22$, p. 190. Acerca del pedido de cato véase CRISIS GROUP, "Coca, droga y protesta social en Bolivia y Perú", Informe sobre América Latina, n¹2, 3 de marzo de 2005, en: $\quad$ https://www.files.ethz.ch/isn/27322/012_coca_drugs_and_social_protest_in_bolivia_and_peru_sp.pdf [visitado el 07.05.2017], p. 12.

${ }^{103}$ ACHÁ, Desproporcionalidad, cit. nota nº 44, p. 5.

104 TRANSNATIONAL INSTITUTE, “¿Coca sí, Coca no? Opciones legales para la hoja de coca”, Drogas y Conflicto. Documentos de Debate, nº (mayo 2006), p. 10, en: http://www.undrugcontrol.info/images/stories/documents/debate13s.pdf [visitado el 25.02.2017].

105 Véase la crítica en la editorial Página Siete, "Detrás del cato de coca", 29 de julio 2014, en: http://www.paginasiete.bo/opinion/2014/7/29/detras-cato-coca-27903.html [visitado el 25.02.2017].

${ }^{106}$ MESA GISBERT, Presidencia, cit. nota n ${ }^{\circ} 22$, p. 190. 
Polit. crim. Vol. 13, № 25 (Julio 2018) Art. 8, pp. 264-321.

[http://www.politicacriminal.cl/Vol_13/n_25/Vol13N25A8.pdf]

número de muertos y heridos". ${ }^{107} \mathrm{El}$ impacto político fue que en las elecciones del 2005, el máximo dirigente de los cultivadores de hoja de coca del Trópico de Cochabamba fue elegido Presidente de la República con casi el $54 \%$ de los votos. ${ }^{108}$ Una vez investido presidente, en enero 2006, Morales anuncia el giro de 180 grados de la política anti-drogas bajo el slogan "coca sí, cocaína no". ${ }^{109}$ Se pone en marcha el proceso denominado oficialmente como la "nacionalización de la política contra el narcotráfico".

En marzo de 2006, el nuevo gobierno crea un Viceministerio de Coca y Desarrollo Integral a cargo de "proponer, coordinar e implementar políticas de industrialización, comercialización, uso benéfico medicinal, cultural y exportación legal de la hoja de coca" y de "formular e implementar políticas de desarrollo integral y sostenible de las regiones productoras de coca". ${ }^{110}$

En 2007, el CONALTID publica su "Estrategia de lucha contra el narcotráfico y revalorización de la hoja de coca 2007-2010" donde se esboza el cambio de paradigma de la nueva política anti-narcotráfico. Morales explica en la presentación del informe: "planteamos la estabilidad y control de los cultivos de coca en un rango que permita niveles dignos de sobrevivencia para los productores cocalero". ${ }^{111} \mathrm{La}$ institución alega que es necesario acabar con las políticas "impuestas desde afuera" para poder "reducir el potencial de producción de cocaína en Bolivia a través de medidas de control social de las culturas, interdicción del narcotráfico y acciones de prevención". ${ }^{112}$ Con la nueva estrategia, CONALTID no propone legalizar directamente el "cato" de coca si no "racionalizar, estabilizar y controlar la producción de hoja de coca a un nivel sostenible". ${ }^{113}$ Estrategia a implementar con participación social siendo el cato la "base de la racionalización". El CONALTID considera así que "un tercio de una cancha de fútbol que permite seguridad y previsibilidad a los productores, y bases para la acción concertada". ${ }^{114}$

107 TRANSNATIONAL INSTITUTE, "Coca", cit. nota n ${ }^{\circ}$ 104, p. 12.

${ }^{108}$ Lazarte ve en la victoria electoral de Evo Morales el "cambio más importante desde la fundación de la República en las élites gobernantes y la historia ya no será igual hacia delante". LAZARTE, cit. nota n ${ }^{\circ} 68, \mathrm{p}$. 21. Por su lado, Roncken afirma que su elección despertó grandes esperanzas. RONCKEN, Theo; ACHÁ, Gloria, Vivir bien y Estado penal. Políticas que no riman, Cochabamba: Acción Andina y Colectivo de Estudios de Drogas y Derecho, 2013, p. https://www.wola.org/sites/default/files/Drug\%20Policy/Vivir\%20Bien\%20y\%20Estado\%20Penal\%20BO.pd f [visitado el 25.02.2017].

${ }^{109}$ Véase el análisis de la inclusión de la hoja de coca en la Convención como un "error histórico" del TRANSNATIONAL INSTITUTE, "Coca", cit. nota n 104, pp. 4-9.

${ }^{110}$ Art. 72 del Decreto Supremo $N^{\circ} 28631$ de 8 de marzo de 2006. Después de la aprobación de la nueva Constitución en 2009 se regulan las competencias del Viceministerio de Coca y Desarrollo Integral en el art. 113 del Decreto Supremo 29894 del 7 de febrero 2009.

${ }^{111}$ CONALTID, Estrategia, cit. nota ${ }^{\circ} 63$, p. 4.

${ }^{112}$ CONALTID, Estrategia, cit. nota n ${ }^{\circ} 63$, p. 29.

${ }^{113}$ CONALTID, Estrategia, cit. nota ${ }^{\circ} 63$, p. 30.

${ }^{114}$ CONALTID, Estrategia, cit. nota n ${ }^{\circ}$ 63, p. 31 . 


\section{STIPPEL, Jörg; SERRANO, Juan. "La nacionalización} de la lucha contra el narcotráfico en Bolivia".

La nueva estrategia generó inquietud en algunos organismos internacionales que temían que Bolivia incumpliera las convenciones internacionales en la materia. ${ }^{115}$ La JIFE en 2008 "recuerda" al Gobierno de Bolivia la prohibición por el derecho internacional del "consumo de la hoja de coca sin la extracción previa de sus principales alcaloides activos, incluida la cocaína, a menos que sea con fines terapéuticos". ${ }^{116}$

A pesar de estas advertencias, el gobierno comienza una ambiciosa refundación de la institucionalidad pública en materia de drogas disociando claramente el cultivo, el consumo y el tráfico. En 2010, se crea el Consejo Nacional de Revalorización, Producción, Comercialización e Industrialización de la Hoja de Coca (CONCOCA) que se convierte en el máximo organismo para la definición y ejecución de las políticas de revalorización, industrialización y comercialización de la hoja de coca. ${ }^{117}$ Por su parte se implementa una reforma integral del CONALTID responsable de la definición y ejecución de las políticas de lucha contra el tráfico ilícito de drogas y sustancias controladas. El consejo queda así integrado por el Ministerios de Relaciones Exteriores, de la Presidencia, de Gobierno, de Defensa y de Salud y Deportes.

En 2011, CONALTID publica la "Nueva Estrategia de Política Contra el Narcotráfico y Reducción de Cultivos Excedentarios de Coca 2011-2015" basada la triple reducción de oferta, demanda y cultivos excedentarios de coca. ${ }^{118}$ En la nueva estrategia ya no aparece el cato de coca como idea fuerza para la racionalización de la producción de coca. El "Fortalecimiento del control del "cato de coca" en el Trópico de Cochabamba y Caranavi" se convierte en meta formal de la estrategia de fortalecimiento del control social. ${ }^{119}$ En ese contexto, antes de las elecciones presidenciales de 2014, Morales advirtió a los integrantes de las federaciones de productores de la coca que ningún miembro de la organización puede tener "dos o tres catos de coca, está prohibido". ${ }^{120}$ La promesa de legalizar el cato de coca no fue por tanto cumplida.

A pesar de las dos estrategias de lucha contra el narcotráfico elaboradas y publicadas por CONALTID, el Departamento de Estado de los Estados Unidos advierte en 2015 que Bolivia ha fracasado en el desarrollo y ejecución de una estrategia nacional de control de

\footnotetext{
${ }^{115}$ La Comisión Interamericana para el Control del Abuso de Drogas (CICAD) manifestó su "preocupación ante la "Estrategia de Lucha contra el Narcotráfico y Revalorización de la hoja de coca, 2007-2010" que contiene "aspectos que generan inquietud respecto al compromiso y cumplimiento de Bolivia con las convenciones internacionales, las cuales establecen controles estrictos para la comercialización de productos derivados de la hoja de coca". CICAD; OEA, Bolivia. Evaluación del Progreso de Control de Drogas 2005 2006, 2006, p. 5, en: http://www.cicad.oas.org/mem/reports/4/Full Eval/Bolivia\%20$\% 20$ Fourth\%20Round\%20-\%20ESP.pdf [visitado el 25.02.2017].

116 Véase Lista I de la Convención Única sobre Estupefacientes de 1961. Disponible en: https://www.incb.org/documents/Narcotic-Drugs/1961-Convention/convention_1961_es.pdf [visitado el 25.02.2017].

${ }^{117}$ Art. 2 pár. I y II. y art. 3 del Decreto Supremo 0649 de 29 de septiembre de 2010. Disponible en: http://www.cicad.oas.org/fortalecimiento_institucional/legislations/PDF/BO/decree 0649.pdf [visitado el 25.02.2017].

${ }^{118}$ CONALTID, Estrategia, nota $\mathrm{n}^{\circ}$ 63, p. 15 .

${ }^{119}$ CONALTID, Estrategia, nota n ${ }^{\circ} 63$, p. 40.

${ }^{120}$ Véase el artículo periodístico de Página Siete, "Evo pide legalizar el cato de coca después de las elecciones", 21 de julio 2014, en: http://www.paginasiete.bo/nacional/2014/7/21/pide-legalizar-cato-cocadespues-elecciones-27287.html [visitado el 25.02.2017].
} 
drogas. ${ }^{121}$ En cambio, organismos internacionales regionales como la CICAD aplaudieron los logros obtenidos por estas nueva estrategia. ${ }^{122}$

Debemos señalar pese a todo que la supuesta "legalización" del cato de coca vulneraba la Ley 1008. La provincia del Chapare no formaba parte de las zonas de producción tradicional de coca definidas en la ley. Sólo en estas zonas se podían producir "los volúmenes necesarios para atender la demanda para el consumo y usos lícitos". ${ }^{123}$ El Chapare era parte de la "zona de producción excedentaria en transición". ${ }^{124}$ Una zona que según la misma normativa "queda sujeta a planes anuales de reducción, sustitución y desarrollo" en los que la meta era eliminar inicialmente 5.000 hectáreas anuales para alcanzar la meta de 8.000 hectáreas anuales. Recordemos que la Ley 1008 no permite el cultivo de un cato por familia, sino que exige su paulatina sustitución y erradicación.

El gobierno boliviano era consciente de esta irregularidad y flagrante violación de la legislación en vigor. ${ }^{125}$ Ya en 2011 prometía una pronta revisión de la Ley 1008 y la aprobación de una Ley General de la Coca. ${ }^{126}$ Esa promesa se cumplió en marzo de 2017 al publicarse la Ley General de Coca. Esta nueva normativa deroga todas las normas relacionadas a las zonas de producción y actividades de erradicación contempladas en la Ley 1008. ${ }^{127}$ Vamos a volver sobre el contenido de esta ley más adelante.

\subsection{La expulsión de la DEA}

Otro hito en el proceso de nacionalización de la política anti-narcótica fue la expulsión de

${ }^{121}$ UNITED STATES DEPARTMENT OF STATE, International Narcotics Control, Strategy Report. Volume I Drug and Chemical Control, Bureau for International Narcotics and Law Enforcement Affairs, vol. 1 (marzo 2015), en: https://www.state.gov/documents/organization/239560.pdf [visitado el 25.02.2017], p. 12.

122 CICAD; OEA, Bolivia. Evaluación del Progreso de Control de Drogas 2007-2009, 2010, en: http://www.cicad.oas.org/mem/reports/5/Full_Eval/Bolivia\%20-\%205ta\%20Rd\%20-\%20ESP.pdf [visitado el 25.02.2017], p. 5.

${ }^{123}$ Art. 9 de la ley 1008. Algunas de estas zonas comprenden están ubicadas en el Departamento de La Paz, específicamente Nor y Sud Yungas.

${ }^{124}$ Así lo establece el art. 10 de la Ley 1008.

${ }^{125}$ El Departamento de Estado de Estados Unidos opinaba: "Bolivian government policies and actions are not in line with international drug control standards. Such policies include Bolivia's promotion of the idea that coca leaf can be used generally for commercial products, as well as its de facto allowance of 20,000 hectares of legal cultivation, 8,000 hectares over the 12,000 hectare limit set by the country's own law and roughly 6,000 more than the European Union determined was needed for Bolivia's consumption needs". UNITED STATES DEPARTMENT OF STATE, International, cit. nota $\mathrm{n}^{\circ}$ 121, p. 12.

${ }^{126}$ La Estrategia de CONALTID indica que: "Para la revalorización y dignificación de la hoja de coca y su industrialización, corresponde propiciar el cambio del status jurídico en las convenciones internacionales a partir de la revisión de la Ley 1008 y la reforma integral del marco legal existente, misma que se traducirá en dos cuerpos legales: la Ley General de la Coca y la Ley General de Sustancias Controladas, además de promover otras normativas complementarias que sirvan de instrumentos legales eficaces que permitan la lucha contra el narcotráfico. La Ley General de la Coca promoverá el desarrollo integral de la hoja de coca, regulará la producción, comercialización y trasformación productiva de la coca, a través del control social e interdicción; y evitará su desvío para usos ilícitos”. CONALTID, Estrategia, nota nº 63, p. 21.

${ }^{127}$ La disposición derogatoria y abrogatoria única de la Ley 906, publicada el 8 de marzo 2017, deroga los artículos 1 a 31 de la Ley 1008. 


\section{STIPPEL, Jörg; SERRANO, Juan. "La nacionalización}

de la lucha contra el narcotráfico en Bolivia”.

la DEA, organismo percibido como el brazo derecho de la embajada de Estados Unidos. A fines del 2008, Evo Morales suspendió todas las actividades de la DEA en Bolivia acusándoles de apoyar actividades subversivas contra su gobierno que promovían un "golpe civil" en Bolivia según sus propias palabras. ${ }^{128}$ El Departamento de Estado de Estados Unidos afirmó que la posterior expulsión de todo el personal de la DEA en 2009 comprometía seriamente las posibilidades de Bolivia de dirigir operaciones antinarcóticos. ${ }^{129}$ En 2014, el presidente Barack Obama adoptó el decreto que identifica a Bolivia como uno de los países que en mayor medida producen o permiten el tránsito de drogas ilícitas. ${ }^{130} \mathrm{El}$ presidente Morales alegó a su vez que la DEA "se quedaba con el 50\% de la cocaína" para financiar actividades ilegales y que además directa o indirectamente "protegía al narcotráfico". ${ }^{131}$

Curiosamente con la expulsión de la DEA no terminó definitivamente la cooperación en materia de lucha contra el narcotráfico. Según el Departamento del Estado de los Estados Unidos, la asistencia no finalizó hasta diciembre del 2013. De ser cierto, la cooperación se prolongó medio año tras la decisión del gobierno de Morales de expulsar, en mayo del 2013, a la agencia de cooperación internacional de Estados Unidos, USAID, acusándoles de seguir conspirando contra su gobierno ${ }^{132}$ El gobierno boliviano evitó así afectar operaciones en curso. ${ }^{133}$

Esta política podría parecer contradictoria. El gobierno acusó a una agencia de cooperación de otro Estado de conspirar en su contra pero le permitió concluir que los proyectos que se encontraban en plena ejecución. No obstante, la expulsión de la DEA se presentó a la opinión pública como la ruptura definitiva con la política criminal trasplantada iniciada con la aprobación de la Ley 1008. Desde ese momento Bolivia se independizó formal y

${ }^{128}$ Véase el artículo La Nación, "Evo Morales suspendió las actividades de la DEA", 1 de noviembre 2008, en: $\quad$ http://www.lanacion.com.ar/1065652-evo-morales-suspendio-las-actividades-de-la-dea-en-bolivia [visitado el 24.02.2017].

${ }^{129}$ UNITED STATES DEPARTMENT OF STATE, International, cit. nota $\mathrm{n}^{\circ} 121, \mathrm{p} .12$.

${ }^{130}$ Presidential Determination Nr. 2014-15 citada en UNITED STATES DEPARTMENT OF STATE, International, cit. nota $\mathrm{n}^{\circ} 121$, pp. 7 y ss.

${ }^{131}$ Véase la noticia "Evo Morales acusa a la DEA de "robar" 50\% de cocaína incautada", teleSUR, 28 de junio 2016, en: http://www.telesurtv.net/news/Evo-Morales-acusa-a-la-DEA-de-robar-50-de-cocaina-incautada20160628-0002.html [visitado el 25.02.2017]; Morales declaró a los medios en este sentido que "afirmar que con el abandono de la DEA van a aumentar los cultivos de coca, la producción de la cocaína, es falso; cuando más bien directa o indirectamente la DEA era la que protegía al narcotráfico", citado por VICEMINISTERIO DE DEFENSA SOCIAL Y SUSTANCIAS CONTROLADAS, Memoria Institucional 2013, 2013, en: http://www.vds.gob.bo/wp-content/uploads/2016/04/MEMORIA-2013.pdf [visitado el 24.02.2017], p. 10.

${ }_{132}$ Véase el artículo de La Razón, "Evo expulsa a USAID de Bolivia tras acusarla de injerencia política", 2 de mayo 2013, en: http://www.la-razon.com/economia/Evo-Usaid-Bolivia-injerenciapolitica 0 1825617424.html [visitado el 24.02.2017].

${ }^{133}$ El artículo citado en la nota anterior ( ${ }^{\circ}$ 137) indica que "la ministra de Planificación, Viviana Caro, insistió en que los proyectos que están en plena ejecución por la agencia no se verán afectados". No obstante, el Departamento de Estado de los Estados Unidos indica que representantes del gobierno de Bolivia seguía pidiendo asistencia técnica: "Formal U.S. counternarcotics assistance to Bolivia ended on December 31, 2013. However, the United States recognizes that the drug trade is a global problem and, due to its recognized technical expertise, continues to receive requests for assistance from representatives of the Government of Bolivia and international organizations operating in Bolivia". UNITED STATES DEPARTMENT OF STATE, International, cit. nota $\mathrm{n}^{\mathrm{O}} 121$, p. 115. 
Polit. crim. Vol. 13, № 25 (Julio 2018) Art. 8, pp. 264-321.

[http://www.politicacriminal.cl/Vol_13/n_25/Vol13N25A8.pdf]

simbólicamente de cualquier injerencia externa en sus políticas antinarcóticos nacionales. Se trataba realmente de una señal casi más fuerte que la consagración de la hoja de coca en la propia Constitución del Estado.

\section{Hacía una política de despenalización}

\subsection{La victoria diplomática del gobierno de Evo Morales: Convención Internacional de Lucha contra las Drogas}

Uno de los mayores hitos de la nueva política criminal boliviana fue la retirada temporal y posterior readhesión a la Convención Única de Estupefacientes de 1961. En 2008 el Oficina de las Naciones Unidas Contra la Droga y el Delito (en adelante UNODC) había invitado al gobierno boliviano "a que siga firmemente comprometido a dar cumplimiento a las obligaciones internacionales que ha contraído en virtud de los tratados", haciendo referencia expresa a la Lista I de la Convención de 1961 que incluye la prohibición de la hoja de coca. ${ }^{134}$ El 29 de junio de 2011, el Senado de Bolivia aprueba la ley que sanciona la retirada formal de la convención indicando en su artículo segundo su intención de volver a adherirse a ella en enero 2012 con una reserva que permita el uso tradicional de la hoja de coca. ${ }^{135}$

En principio la Convención Única de 1961 permitía que un Estado firmante autorizara la masticación de la hoja de coca en su territorio. No obstante la normativa estipula una reserva temporal al determinar que "la masticación de hoja de coca quedará prohibida dentro de los 25 años siguientes a la entrada en vigor de la presente Convención”, plazo que vencía en 1989. ${ }^{136}$ Tras la aprobación de la nueva Constitución en 2009, que reconoce en su artículo 384 la hoja de coca como parte de la cultura, esta exigencia quedó en el limbo jurídico.

Para poder volver a ratificar la convención, Bolivia recurrió a otra posibilidad que ofrece la Convención de 1961 que permite la autorización por los Estados firmantes de "reservas distintas". La norma no estipula un límite en cuanto a los contenidos de estas reservas. Se regula únicamente un procedimiento para su aprobación que establece que la reserva queda autorizada si dentro de los 12 meses, a contar de la comunicación formal, no ha habido objeción de un tercio de los Estados. ${ }^{137}$

${ }^{134}$ UNODC, Los tratados de fiscalización internacional de drogas, Viena: Naciones Unidas, 2013, en: https://www.unodc.org/documents/commissions/CND/Int_Drug_Control_Conventions/Ebook/The Internatio nal_Drug_Control_Conventions_S.pdf [visitado el 24.02.2017].

135 Proyecto de Ley $\mathrm{N}^{\circ}$ 0392/2011-2012. Disponible en: http://www.boliviaexterior.com/seccion/2economia/noticia/4570-Sancionan-Ley-que-busca-sacar-el-masticado-de-coca-de-la-lista-de-estupefacientes [visitado el 24.02.2017]. Acerca de las discusiones a nivel internacional véase el artículo INTERNATIONAL DRUG POLICY CONSORTIUM, “La reconciliación jurídica de Bolivia con la Convención Única sobre Estupefacientes", 2011, en: https://www.tni.org/files/publication-downloads/idpc-advocacy-note_boliviawithdraws-from-single-convention-spa.pdf [visitado el 24.02.2017], p. 1.

${ }^{136}$ Véase art. 49 párr. I. letra c. y párr. II. letra e. de la Convención Única de 1962.

137 Véase art. 50 párr. III. de la Convención Única de 1962. 


\section{STIPPEL, Jörg; SERRANO, Juan. "La nacionalización de la lucha contra el narcotráfico en Bolivia".}

Habría sido necesario que una tercera parte de los Estados parte de la Convención - 61 de los 183 - objetaran la reserva de Bolivia. Al expirar la fecha límite para presentar objeciones el 10 de enero de 2013, el gobierno boliviano se apuntó una victoria diplomática, pues tan solo 15 países, entre ellos los Estados Unidos, se opusieron a la reserva. ${ }^{138}$ Los comentarios oficiales de la Convención Única de 1962 arrojan luz sobre la estrategia del gobierno boliviano pues indican que un Estado que ya haya ratificado la Convención no puede recurrir al procedimiento de autorización de reserva descrito previamente. ${ }^{139}$ Por ello era indispensable salirse primero para reingresar con la reserva adoptada. La re-adhesión de Bolivia entró en vigor el 10 de febrero de 2013. ${ }^{140}$ Este episodio de la historia reciente de Bolivia demuestra, que las Convenciones pueden ser modificadas incluso teniendo la voluntad de los Estados Unidos en contra.

\subsection{El cambio de paradigma: consumo como problema de salud pública}

Las publicaciones oficiales del gobierno de Morales sobre la política de drogas se esfuerzan en valorar este cambio de estrategia. Un boletín de CONALTID celebró en 2014 que ahora Bolivia consiguiese erradicar plantaciones de coca "sin el uso de la violencia como ocurría antes del año 2006". ${ }^{141}$ Desde entonces y según el discurso oficial, los esfuerzos de "lucha" contra el narcotráfico adoptaron un nuevo enfoque al centrarse en la reducción de la demanda y no en la persecución del cultivo. La nueva política dice así privilegiar medidas de prevención del consumo ${ }^{142}$ y de tratamiento y de rehabilitación de drogodependientes. ${ }^{143}$

${ }^{138}$ Véase le comunicado del UNODC, "Bolivia vuelve al convenio sobre drogas de la ONU, mientras que hace una excepción en cuanto a masticación de hoja de coca", 16 de enero 2016, en: https://www.unodc.org/lpo-brazil/es/frontpage/2013/01/16-bolivia-volta-a-aderir-a-convencao-sobre-drogasda-onu-com-excecao-para-folha-de-coca.html [visitado el 24.02.2017].

${ }^{139}$ Véase el comentario 4 del art. 50 en NACIONES UNIDAS, Comentarios a la Convención Única de 1961 sobre Estupefacientes, Naciones Unidas: en: http://www.unodc.org/documents/treaties/organized_crime/Drug\%20Convention/Comentarios_a_la_convenci on_unica_de 1961.pdf [visitado el 24.02.2017], p. 519.

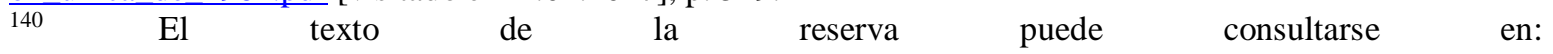
https://treaties.un.org/Pages/ViewDetails.aspx?src=TREATY\&mtdsg no=VI$18 \&$ chapter $=6 \&$ clang $=$ en\#EndDec [visitado el 24.02.2017].

141 CONALTID, Boletín Informativo, julio 2014, en: http://conaltid.gob.bo/web/views/layout/assets/frontend/boletines/boletin-2014.pdf [visitado el 24.02.2017], p. 1.

${ }^{142}$ La Ley 1008 entiende por consumo “el uso ocasional, periódico, habitual o permanente de sustancias controladas"(art. 33 letra n.). La norma establece que "el dependiente y el consumidor no habitual que fuere sorprendido en posesión de sustancias controladas en cantidades mínimas que se supone son para su consumo personal inmediato, será internado en un instituto de farmacodependencia público o privado para su tratamiento hasta que se tenga convicción de su rehabilitación. La cantidad mínima para consumo personal inmediato será determinada previo dictamen de dos especialistas de un instituto de farmacodependencia público" (art. 49). En aplicación de esta regla hasta consumidores ocasionales de sustancias controladas, por ejemplo marihuana, tienen que ser internados para recibir un tratamiento. No importa si el consumo es problemático o no. Uno podría preguntarse si la internación de consumidores no habituales con drogodependientes es una medida apropiada para disminuir la demanda. Lo contrario parece probable, pues los consumidores ocasionales pueden conocer en los dependientes a posibles nuevos proveedores.

${ }^{143}$ Un estudio del 2013 analiza las drogas que los pacientes atendidos en los centros de tratamiento en los principales ciudades de Bolivia consumían. A nivel nacional existían 2010 un total de 80 comunidades terapéuticas y centros de tratamiento y rehabilitación con un total de 2880 plazas para el tratamiento residencial y 1213 para la atención no residencial. PUENTE INVESTIGACIÓN Y ENLACE; ASOCIACIÓN BOLIVIANA DE COMUNIDADES TERAUPÉTICAS, Estudio sobre drogas en pacientes en centros de 
Debemos señalar sin embargo que este tipo de medidas son anteriores a la llegada del MAS al poder. La propia Ley 1008 dedica todo el Titulo VII (arts. 136 a 144) al tema de Tratamiento, Rehabilitación y Reinserción social. El Estado se compromete es este articulado a crear "institutos y centros de investigación, prevención, tratamiento y rehabilitación para la dependencia química, física y psíquica (farmacodependencia), en el tratamiento, rehabilitación y reinserción social de los consumidores de sustancias controladas". ${ }^{144}$ Existía además una institucionalidad especializada en la prevención, la Dirección Nacional de Prevención Integral del Uso Indebido de Drogas, Tratamiento, Rehabilitación y Reinserción Social (en adelante DINAPRE) ${ }^{145}$ creada en 1986 y en cada Departamento se instalaron Consejos de Prevención, Tratamiento y Rehabilitación de Drogodependencia (en adelante COPRE). ${ }^{146}$

La CICAD resalta que Bolivia tenía también una "Estrategia Nacional de Reducción de la Demanda de Drogas, que se expresa en el Plan Nacional de Prevención y Rehabilitación 1998-2002" que contaban con "dos Programas Nacionales, uno de Prevención y otro de Rehabilitación, que a su vez contienen subprogramas de comunicación, investigación, participación social, educación-capacitación y fortalecimiento de centros de rehabilitación". ${ }^{147}$ También la UNODC describe los esfuerzos de su proyecto de prevención del abuso de drogas que entre 2000 a 2006 y alega haber capacitado a 4.900 profesores en 1.000 escuelas y instruido a 592.000 estudiantes. ${ }^{148}$

No obstante, es cierto, que en los años de militarización de la política criminal, los fondos destinados a la erradicación de la hoja de coca, superaban considerablemente aquellos destinados a la prevención y el tratamiento. Un informe de CICAD indica que según el gobierno boliviano, el presupuesto asignado el año 2001 para reducir la demanda mediante la prevención, el tratamiento y la reinserción social era de 381.000 dólares estadounidenses para el área de prevención al igual que para el tratamiento y rehabilitación. Además precisa que para "la reinserción social y seguimiento el monto asignado es de 132.713 dólares idéntica suma se destina para investigación y capacitación". ${ }^{149}$ No obstante no se trataba de

tratamiento de las principales ciudades de Bolivia. Informe final 2013, 2014, en: http://www.piebolivia.org.bo/flip/estudiodrogas.pdf [visitado el 24.02.2017], p. 6.

${ }^{144}$ Art. 136 de la Ley 1008.

${ }^{145}$ DINAPRE realizó varios estudios sobre el problema de la dependencia. Algunos están disponibles en la red. Entre ellos un estudio MINISTERIO DE PREVISIÓN SOCIAL Y SALUD PÚBLICA, La prevalencia del uso indebido de drogas en Bolivia (población urbana), 1993, en: http://pdf.usaid.gov/pdf docs/Pnado265.pdf [visitado el 24.02.2017].

${ }^{146}$ ACHÁ, Rose M., Consumo y consumidores de drogas en Bolivia, Colectivo de Estudios de Drogas y Derecho, 2010, en: http://www.drogasyderecho.org/publicaciones/prop_del/bolivia-usuarios.pdf [visitado el 25.02.2017].

${ }^{147}$ CICAD; OEA, Bolivia. Evaluación del Progreso de Control de Drogas. Mecanismo de Evaluación Multilateral 1999-2000, 1999, en: http://www.cicad.oas.org/mem/reports/1/Full_Eval/Bolivia_spa.rev2.pdf [visitado el 25.02.2017], p. 2.

148 UNODC, Making the world safer from crime, drugs and terrorism, UNODC-UE, 2015, en: https://www.unodc.org/documents/brussels/EU-UNODC_10_Years_Brochure/EU-UNODC-

brochure_WEB.pdf [visitado el 24.02.2017], p. 48.

${ }^{149}$ CICAD, Bolivia, cit. nota n ${ }^{\circ}$ 89, p. 2. 


\section{STIPPEL, Jörg; SERRANO, Juan. "La nacionalización de la lucha contra el narcotráfico en Bolivia".}

fondos propios pues "la mayoría de estos recursos provienen de fondos de la cooperación internacional". ${ }^{150} \mathrm{Si}$ sumamos todas esas cifras, vemos que en el 2001 se destinaron alrededor de 650.000 dólares en medidas para la reducción de la demanda. Para la implementación del Plan Dignidad que conllevaba la militarización del conflicto, se destinaron más de 900.000.000 dólares.

Desde esta perspectiva parece plausible la afirmación realizada por el CONALTID en su Estrategia 2007-2010 según la cual la prevención y el tratamiento del consumo de drogas no han sido "parte de las políticas prioritarias de las diferentes gestiones gubernamentales". Para fundamentar esto la organización gubernamental cita estadísticas elaboradas previamente con el apoyo de fondos de USAID. El CONALTID dice así que "el consumo de drogas ilegales se incrementó entre 1992 y 2005 del 1,7 \% al 4,51\% de la población. Los productos mayormente consumidos son la marihuana (del 0,2 \% al 1,97 \% sobre el mismo período), la cocaína (del $0,1 \%$ al $1,33 \%$ ) y la pasta base (del 0,2 \% al 1,21 \%). Mientras tanto el elevado consumo de drogas legales (cigarro y alcohol) no ha cambiado sustantivamente". 151

Desde marzo 2006, el Viceministro de Salud del Ministerio de Salud y Deportes queda a cargo de "proponer sistemas y estrategias de prevención, rehabilitación y reinserción social" para personas consumidoras de sustancias psicoactivas legales e ilegales. ${ }^{152}$ En 2013 el Viceministro de Defensa Social y Sustancias Controladas, Felipe Cáceres, presenta el "Plan Nacional de Reducción de la Demanda de Drogas en Bolivia 2013-2017". Según las declaraciones oficiales, su implementación implicaba una inversión de 49.9000.000 dólares estadounidenses. El objetivo general era la reducción de la vulnerabilidad al consumo de alcohol y otras drogas en la población boliviana. Se pretendía focalizar el esfuerzo en grupos de mayor riesgo a partir de estrategias integrales de prevención. ${ }^{153}$ La UNODC llega a felicitar al gobierno boliviano por el desarrollo de este plan considerado "en línea con los estándares internacionales". 154

En el mismo periodo a nivel internacional también observamos una inflexión en el discurso. Cuando el Secretario General de la OEA el antiguo ministro chileno José Miguel Insulza presentó en 2010 la "Estrategia Hemisférica sobre Drogas" de la CICAD, afirmó que esperaba que esta ayude "a los países a desarrollar políticas que se enfoquen no sólo en el suministro y control de la droga, sino también en su dependencia". Insulza se hace eco así del cambio de paradigma en la política antidrogas protagonizado por Bolivia que considera el consumo y la dependencia de drogas como problemas de salud pública y no únicamente

\footnotetext{
${ }^{150}$ CICAD, Bolivia, cit. nota $\mathrm{n}^{\text {o }} 89$, p. 2.

${ }^{151}$ CONALTID, Boletín, cit. nota $\mathrm{n}^{\circ} 141$, p. 21.

152 Art. 87 letra o del Decreto Supremo Nº 28631 del 8 de marzo de 2006.

${ }^{153}$ El plan fue desarrollado con el apoyo técnico y financiero de Caritas Alemania. UNODC, "UNODC felicita al Gobierno por el desarrollo del 'Plan Nacional de Reducción de la Demanda de Drogas' y destaca logros del proyecto de prevención”, en: https://www.unodc.org/bolivia/es/stories/presentacion_plan_reduccion_demanda_de_drogas.html_[visitado el 24.02.2017]; VICEMINISTERIO, cit. nota $n^{\circ} 131$, p. 27.

${ }^{154}$ UNODC, "UNODC", cit. nota n $^{\circ} 153$, p. 1 y s.
} 
como actos criminales. ${ }^{155} \mathrm{La}$ estrategia de la CICAD reconoce en este sentido que la "dependencia hacia las drogas es un mal crónico y reincidente que debe ser tratado como un componente clave en la política de salud pública. Es una enfermedad que está a la par con enfermedades como la diabetes, la hipertensión o el asma y que requiere de un tratamiento médico adecuado para atacar sus causas profundas". ${ }^{156}$

Tras la legalización del "cato" de coca en 2003 durante el gobierno de Mesa Gisbert, con el primer gobierno de Morales operó un cambio de paradigma que deja atrás los tiempos de la "guerra contra el narcotráfico". Existe, al menos en el discurso oficial, un mayor énfasis en la reducción de la demanda y así en el tratamiento y la prevención de la drogodependencia. A pesar de este desarrollo positivo, la investigadora boliviana Gloria Achá critica que la práctica aún no coincide con el discurso oficial. Opina que el consumo de drogas sigue siendo abordado, tanto por el Estado como por la sociedad, con "un enfoque represivo y autoritario, que simplifica la realidad, y que asume a la represión penal y al castigo como medios idóneos para resolver la problemática vinculada al consumo de sustancias psicoactivas". ${ }^{157}$ En efecto, el cambio del discurso oficial que acompaña la legalización del uso de la hoja de coca y la regulación de su producción, no equivale a la superación de la prohibición en materia de drogas. Aún no es evidente que camino va a seguir la política de drogas en Bolivia después de décadas de represión.

\subsection{La Ley General de Coca}

El más reciente hito de la política criminal boliviana es la promulgación de la Ley General de la Coca en marzo del 2017. La normativa es innovadora en varias áreas. Los principios resaltan la decisión asumida en la Constitución, declarando la coca como "planta milenaria, originaria y tradicional con cualidades benéficas para el pueblo boliviano". Como si el legislador quisiera enviar un mensaje a la JIFE, el mismo artículo resalta que la coca "en su estado natural no es estupefaciente". ${ }^{158}$ Para poner énfasis en el arraigo cultural de la coca, se habla de los métodos ancestrales que se usan para su producción "en convivencia armónica con la Madre Tierra". ${ }^{159}$ Otro principio se refiere a la coca como recurso natural estratégico que contribuye, entre otros, a la soberanía alimentaria. Contrario a la visión de

\footnotetext{
${ }^{155}$ El art. 33 de la Ley 1008 define al consumo como "el uso ocasional, periódico, habitual o permanente de sustancias controladas". El Colectivo de Estudios de Drogas y Derecho considera que esta disposición "no hace distinción entre consumo problemático y no problemático, ni entre consumo habitual y ocasional; al contrario, considera que aquel consumidor de drogas de uso ilícito, así sea un consumidor ocasional, es alguien que genera un riesgo o un peligro para la sociedad. Por tanto, el artículo 49 de la Ley establece la internación obligatoria tanto del dependiente como del consumidor no habitual". COLECTIVO DE ESTUDIOS DE DROGAS Y DERECHO, En busca de los derechos: Usuarios de drogas y las respuestas estatales en América Latina, México: CEDD, 2014, p. 54, en: https://www.wola.org/sites/default/files/Drug\%20Policy/CEDD-Reporte_Completo\%209\%20julio.pdf [visitado el 25.02.2017].

${ }^{156}$ Palabras de Insulza citadas en CICAD; OEA, Estrategia hemisférica sobre drogas. Plan de acción 2011 2015, 2010, en: http://www.cicad.oas.org/main/aboutcicad/basicdocuments/Estrategia_drogas.pdf [visitado el 25.02.2017], p. 1.

157 ACHÁ, Desproporcionalidad, cit. nota n 44, p. 29.

158 Artículo 4 letra a de la Ley General de la Coca.

${ }^{159}$ Artículo 4 letra b. de la Ley General de la Coca.
} 


\section{STIPPEL, Jörg; SERRANO, Juan. "La nacionalización} de la lucha contra el narcotráfico en Bolivia".

las Convenciones internacionales, la hoja de coca es percibida como elemento que aporta a la salud. ${ }^{160}$

La ley estipula varias formas de uso de la hoja de coca: la masticación - acullicu, pijcheo, coqueo o boleo -, el uso para fines rituales, medicinales, alimenticios, investigativos e industriales. ${ }^{161}$ En cuanto a la producción, la normativa crea zonas autorizadas y zonas no autorizadas de producción de la hoja de coca. ${ }^{162}$ Para su fiscalización reconoce y dice querer promover el control social comunitario sobre la producción de la coca, igual indica que ese no debe ser sustitutivo al control y fiscalización del Estado. ${ }^{163}$

La mayor diferencia en relación a la legislación anterior, es la respuesta prevista para infracciones a las normas sobre producción, porte, comercialización y transporte de la hoja de coca. Estipula que la inobservancia de las normas acarrea sanciones administrativas, no penales. A pesar de ello, la regulación permite que otras normas establezcan otras sanciones. ${ }^{164} \mathrm{Si}$ bien la Ley General de la Coca no deroga las normas penales de la Ley 1008, deja en claro que cuando se trata de cualquier conducta relacionada a la hoja de coca, la respuesta a infracción no debe ser penal.

Otro punto interesante es el encargo político que enuncia la normativa, pues obliga que el Estado promueva en todos los ámbitos internacionales una modificación de las Convenciones internacionales. El legislador boliviano quiere lograr que se despenalice a nivel internacional la hoja de coca y que se abran los mercados internacionales para poder comercializar los productos industrializados y derivados de la coca. ${ }^{165}$

Vemos como Bolivia concluye, con esta normativa y en relación a la hoja de coca, el proceso de nacionalización de la política de drogas. Con ello el país inaugura una alternativa al prohibicionismo militarizado para la región andina, la legitimación del uso de la hoja de coca en lugar de la legalización de la cocaína. Alternativa que deberá estar acompañada de una política económica y comercial que promueva la industrialización y exportación de la hoja de coca con fines lícitos. Queda por ver qué decisiones adoptará Bolivia en los otros campos de la política anti-narcótica.

\section{Balance estadístico del impacto de reformas y medidas}

Después de analizar la evolución normativa y política de la política de drogas, cabe preguntarse cuál fue su impacto real en el sistema judicial y penitenciario a partir del examen de las estadísticas disponibles de 2000 a 2016 y de acceso público en su mayoría. Sin embargo este el análisis se encuentra irremediablemente incompleto debido a las lagunas existentes en los datos. No contamos, por ejemplo, con cifras sobre personas condenadas con sentencia firme por delitos relacionados a la Ley 1008. Tampoco podemos

\footnotetext{
160 Artículo 4 letra e. de la Ley General de la Coca.

161 Artículo 13 letra a. a e. de la Ley General de la Coca.

162 Artículo 15 de la Ley General de Coca.

163 Artículo 7 de la Ley General de la Coca.

${ }^{164}$ Artículo 28 pár. I. de la Ley General de la Coca.

165 Artículo 27 de la Ley General de Coca.
} 
Polit. crim. Vol. 13, № 25 (Julio 2018) Art. 8, pp. 264-321.

[http://www.politicacriminal.cl/Vol_13/n_25/Vol13N25A8.pdf]

saber en qué porcentaje de casos se ha condenado a una persona por posesión, producción o tráfico de sustancias controladas, ni sabemos qué cantidades de qué tipo de drogas portaron estas personas. Las estadísticas públicas disponibles carecen de la necesaria precisión y muchas veces son contradictorias en sí como hemos analizado en otro momento. ${ }^{166}$

\subsection{Cantidad de "personas aprehendidas"}

En relación a las cifras de "personas aprehendidas" vemos que entre 2000 y 2003, la policía detuvo cada año aproximadamente 2.500 personas en aplicación de la Ley 1008. En 2003, el número total sube a más que 3.500 y sigue creciendo los años siguientes para llegar el 2006 a 4.198 aprehensiones. Desde entonces las cifras se mantienen relativamente altas, en comparación con los primeros años del siglo, llegando el 2013 a un máximo de 4.580 aprehensiones. La siguiente tabla contempla este resultado:

Tabla 1: Número de personas aprehendidas/detenidas por actividades penadas por la Ley 1008. ${ }^{167}$

\begin{tabular}{|l|l|l|l|l|l|l|l|l|l|l|l|l|l|l|l|l|l|}
\hline DESCRIP & $\mathbf{2 0 0}$ & $\mathbf{2 0 0}$ & $\mathbf{2 0 0}$ & $\mathbf{2 0 0}$ & $\mathbf{2 0 0}$ & $\mathbf{2 0 0}$ & $\mathbf{2 0 0}$ & $\mathbf{2 0 0}$ & $\mathbf{2 0 0}$ & $\mathbf{2 0 0}$ & $\mathbf{2 0 1}$ & $\mathbf{2 0 1}$ & $\mathbf{2 0 1}$ & $\mathbf{2 0 1}$ & $\mathbf{2 0 1}$ & $\mathbf{2 0 1}$ & $\mathbf{2 0 1}$ \\
CION & $\mathbf{0}$ & $\mathbf{1}$ & $\mathbf{2}$ & $\mathbf{3}$ & $\mathbf{4}$ & $\mathbf{5}$ & $\mathbf{6}$ & $\mathbf{7}$ & $\mathbf{8}$ & $\mathbf{9}$ & $\mathbf{0}$ & $\mathbf{1}$ & $\mathbf{2}$ & $\mathbf{3}^{\mathbf{1 6 8}}$ & $\mathbf{4}^{\mathbf{1 6 9}}$ & $\mathbf{5}^{\mathbf{1 7 0}}$ & $\mathbf{6}^{\mathbf{1 7 1}}$ \\
\hline & 2.4 & 2.3 & 2.6 & 3.5 & 3.9 & 4.1 & 4.1 & 3.6 & 3.5 & 3.2 & 3.4 & 3.9 & 4.3 & 4.58 & 3.45 & 3.22 & 3.59 \\
BOLIVIA & 87 & 36 & 95 & 23 & 22 & 54 & 98 & 19 & 25 & 20 & 34 & 30 & 17 & 0 & 5 & 7 & 8 \\
\hline
\end{tabular}

Podemos constatar que las cifras más bajas de aprehensiones por actividades penadas por la Ley 1008 se dieron en la época de la máxima militarización de la lucha anti-narcótica al inicio del siglo. El aumento de la tasa de aprehensiones en casi un $50 \%$ (de 2.487 en 2000 a 4.154 en 2005) coincide con la época posterior a la legalización del cato de coca en el gobierno de Mesa Gisbert y la disminución de las operaciones militares en las actividades de erradicación. Vemos, a su vez, que la expulsión de la DEA no tuvo un impacto considerable en la eventual baja de la tasa de aprehensiones. Si bien entre 2008 y 2009 se dio una leve baja, el año siguiente las cifras varían poco, ascendiendo a 3.434, y a partir de 2011 han subido considerablemente durante varios años. Podemos concluir por tanto que la

\footnotetext{
166 STIPPEL, Jorg; SERRANO MORENO, "Veinte", cit. nota $n^{\circ} 3$.

${ }^{167}$ Datos según el INE y la FELCN. Las estadísticas del INE contemplan datos sobre "personas detenidos" por actividades penadas por la Ley 1008 de los años 2000 al 2012. En cambio, la información disponible en la página de la FELCN indica el número de "aprehensiones" realizadas desde el 2010 hasta el 2016. Usamos esta información para complementar la tabla, porque las cifras de los años 2011 y 2012 coinciden. Para el año 2010 hay una diferencia, pues la página de la FELCN indica un número de 3.735 aprehendidos. En: http://www.felcn.gob.bo/R-Est-2010.aspx [visitado el 08.05.2017]. Los datos hasta 2012 son producidos por el INE. De 2012 a 2016 según la FELCN. La información disponible en la página de la FELCN no diferencia el género de las personas. Véanse los datos del FELCN disponibles en: http://www.felcn.gob.bo/R-Est2014.aspx [visitado el 25.02.2017].

168 VICEMINISTERIO, cit. nota $\mathrm{n}^{\circ} 131$, p. 97.

${ }^{169}$ Datos según FELCN disponibles en: http://www.felcn.gob.bo/R-Est-2014.aspx [visitado el 25.02.2017].

${ }^{170}$ Datos según FELCN disponibles en: http://www.felcn.gob.bo/R-Estadisticas.aspx [visitado el 25.02.2017].

171 Datos según FELCN para el período del 1 enero al 18 de agosto 2016 disponibles en: http://www.felcn.gob.bo/R-Est-2016.aspx [visitado el 25.05.2017].
} 


\section{STIPPEL, Jörg; SERRANO, Juan. "La nacionalización} de la lucha contra el narcotráfico en Bolivia".

expulsión de la DEA no comprometió el éxito de las operaciones antinarcóticos ${ }^{172}$ al contrario de lo sostenido por algunos actores tal y como hemos detallado más arriba.

Para profundizar el análisis, podemos consultar datos sobre la cantidad de personas aprehendidas por tráfico ilícito y posesión de drogas. ${ }^{173}$ Vemos que la cifra más alta de personas aprehendidas por tráfico ilícito de drogas se da el 2006 (2.381) desde entonces la cifra ha quedado debajo de las 2000 aprehensiones anuales. La tendencia visible en las aprehensiones de personas por posesión de droga, es más clara. Se ve un casi constante aumento de 238 personas al inicio del siglo (2000) a 1.456 el 2016. Las cifras muestran a su vez, que el porcentaje de mujeres involucradas en actividades de tráfico ilícito ha aumentado (de 23, $6 \%$ en 2000 a 28,3\% en 2012), en cambio en el mismo periodo temporal vemos una baja porcentual en la aprehensión de mujeres por posesión de drogas (de $18,1 \%$ en 2000 a $12,7 \%$ en 2012). Aquí los detalles:

Tabla 2: Número de personas aprehendidas por tráfico ilícito y posesión de drogas según sexo. ${ }^{174}$

\begin{tabular}{|l|l|l|l|l|l|l|l|l|l|l|l|l|l|}
\hline Año & $\mathbf{2 0 0 0}$ & $\mathbf{2 0 0 1}$ & $\mathbf{2 0 0 2}$ & $\mathbf{2 0 0 3}$ & $\mathbf{2 0 0 4}$ & $\mathbf{2 0 0 5}$ & $\mathbf{2 0 0 6}$ & $\mathbf{2 0 0 7}$ & $\mathbf{2 0 0 8}$ & $\mathbf{2 0 0 9}$ & $\mathbf{2 0 1 0}$ & $\mathbf{2 0 1 1}$ & $\mathbf{2 0 1 2}$ \\
\hline $\begin{array}{l}\text { Total } \\
\text { aprehendido } \\
\text { s por tráfico }\end{array}$ & $\mathbf{1 . 8 1 5}$ & $\mathbf{1 . 4 7 4}$ & $\mathbf{1 . 6 0 6}$ & $\mathbf{2 . 1 6 6}$ & $\mathbf{2 . 3 3 2}$ & $\mathbf{2 . 3 1 4}$ & $\mathbf{2 . 3 8 1}$ & $\mathbf{1 . 8 0 6}$ & $\mathbf{1 . 4 4 7}$ & $\mathbf{1 . 8 6 5}$ & $\mathbf{1 . 3 7 3}$ & $\mathbf{1 . 5 9 8}$ & $\mathbf{1 . 8 7 0}$ \\
\hline Hombres & 1.387 & 1.088 & 1.231 & 1.657 & 1.733 & 1.694 & 1.714 & 1.349 & 1.051 & 1.329 & 887 & 1.160 & 1.341 \\
\hline Mujeres & 428 & 386 & 375 & 509 & 599 & 620 & 667 & 457 & 396 & 536 & 486 & 438 & 529 \\
\hline $\begin{array}{l}\text { Total } \\
\text { aprehendido } \\
\text { s por } \\
\text { posesión de } \\
\text { droga }\end{array}$ & $\mathbf{2 3 8}$ & $\mathbf{2 6 2}$ & $\mathbf{5 0 6}$ & $\mathbf{6 2 5}$ & $\mathbf{7 6 1}$ & $\mathbf{9 5 1}$ & $\mathbf{8 3 7}$ & $\mathbf{9 9 8}$ & $\mathbf{8 0 7}$ & $\mathbf{6 5 4}$ & $\mathbf{8 2 3}$ & $\mathbf{1 . 2 4 6}$ & $\mathbf{1 . 4 5 6}$ \\
\hline Hombres & 195 & 231 & 420 & 521 & 643 & 755 & 690 & 793 & 645 & 525 & 683 & 1.071 & 1.271 \\
\hline \begin{tabular}{l} 
Mujeres \\
\hline
\end{tabular} & 43 & 86 & 104 & 118 & 196 & 147 & 205 & 162 & 129 & 140 & 175 & 185 \\
\hline $\begin{array}{l}\text { Total } \\
\text { aprehendido } \\
\text { s por tráfico } \\
\text { y posesión }\end{array}$ & $\mathbf{2 . 0 5 3}$ & $\mathbf{1 . 7 3 6}$ & $\mathbf{2 . 1 1 2}$ & $\mathbf{2 . 7 9 1}$ & $\mathbf{3 . 0 9 3}$ & $\mathbf{3 2 6 5}$ & $\mathbf{3 . 2 1 8}$ & $\mathbf{2 . 8 0 4}$ & $\mathbf{2 . 2 5 4}$ & $\mathbf{2 5 1 9}$ & $\mathbf{2 . 1 9 6}$ & $\mathbf{2 . 8 4 4}$ & $\mathbf{3 . 3 2 6}$ \\
\hline
\end{tabular}

\footnotetext{
${ }^{172}$ Así lo afirmó el UNITED STATES DEPARTMENT OF STATE, International, cit. nota nº 121, p. 12.

${ }^{173}$ Contamos con ésta información sólo para los años 2000 a 2012, pues la página de la FELCN no contempla esta información.

${ }^{174}$ Los datos de 2000 a 2012 según Instituto Nacional de Estadística de Bolivia, cuadro no 3090505 y cuadro $\mathrm{n}^{\circ} 3090515$ disponibles en: http://www.ine.gob.bo/index.php/introduccion-6/introduccion-6 [visitado el 25.05.2017].
} 
Los datos dejan ver que existe un porcentaje cada año mayor de aprehensiones por posesión y un estancamiento en relación a las aprehensiones realizadas por tráfico ilícito. Si analizamos estos datos en conjunto con los de la tabla anterior, vemos que el aumento de las aprehensiones por delitos relacionados a la Ley 1008 (en el período hasta el 2012), se debe principalmente a un incremento de aprehensiones por posesión de droga y no tanto por tráfico. Este aumento explica, en parte, el aumento de la cantidad de droga incautada en ese periodo. Una posible explicación para el incremento es el crecimiento de la fuerza policial en un $50 \%$ en el periodo estudiado. Con más personal existe una red de control mayor, con ello crece la probabilidad de aprehender a personas que portan drogas.

Es lamentable que la FELCN ya no esté publicando cifras detallando las razones de las aprehensiones. Si tuviéramos los datos de los últimos años, podríamos comprobar si existe una tendencia a la baja de aprehensiones por narcotráfico. Si fuera así, sería preocupante dado que en los últimos años la FELCN afirma haber destruido una cantidad cada año mayor de laboratorios de cristalización, como vamos a ver más adelante.

\subsection{Cantidad de droga incautada}

Si nos fijamos en la cantidad de droga incautada, vemos que, entre 2000 y 2002, disminuyó la cantidad de pasta base (de 5.0 toneladas a 4.7 toneladas), así como la cantidad cocaína incautada (de 555 toneladas a 362 toneladas). De 2003 en adelante, las cifras totales de droga incautada suben constantemente. En el caso de la pasta base, se alcanza el nivel máximo de incautación el año 2012 (32.134 kilos). ${ }^{175}$ La siguiente tabla contempla este resultado:

\footnotetext{
${ }^{175} \mathrm{Si}$ comparamos las incautaciones con los resultados obtenidos por las policías de otros países de la región, sorprende que el año 2015 la policía peruana obtuviera un resultado similar a su par boliviano, decomisando 11,7 toneladas de pasta base de cocaína, 8,5 toneladas de clorhidrato de cocaína, y 92 toneladas de marihuana. En cambio en Colombia se incautaron el año 2015 un total de 42,7 toneladas de pasta base, 253,2 toneladas de clorhidrato de cocaína y 258,2 toneladas de marihuana. Chile, sin ser país productor, incautó el 2014 un total de 9,3 toneladas de pasta base, 4,9 toneladas de clorhidrato de cocaína y 18 toneladas de marihuana. En comparación podemos ver que en uno de los mercados principales de la droga, Europa, se incautaron el 2014 un total de 61,6 toneladas de cocaína. POLICÍA NACIONAL DEL PERÚ, Anuario Estadístico, Lima: Ministerio del Interior, en: https://www.pnp.gob.pe/anuario estadistico/documentos/ANUARIO\%20PNP\%202015\%20DIREST\%20PU BLICACION.pdf [visitado el 08.05.2017], p. 81; OBSERVATORIO DEL NARCOTRÁFICO EN CHILE, Informe 2015, Santiago de Chile: Ministerio Público de Chile, 2015, en: http://www.senda.gob.cl/media/estudios/otrosEstudios/2015_Primer_informe observatorio narcotrafico.pdf [visitado el 08.05.2017], p. 7; OBSERVATORIO EUROPEO DE LAS DROGAS Y LAS TOXICOMANÍAS, Informe Europeo sobre Drogas 2016: Tendencias y novedades, Luxemburgo: Oficina de Publicaciones de la Unión Europea, 2016, en: http://www.emcdda.europa.eu/system/files/publications/2637/TDAT16001ESN.pdf [visitado el 08.05.2017], p. 24 y 25; OBSERVATORIO DE DROGAS DE COLOMBIA, Reporte de drogas de Colombia 2016, Bogotá: Ministerio de Justicia y del Derecho, 2016, en: http://www.odc.gov.co/Portals/1/publicaciones/pdf/odc-libro-

blanco/ODC0100322016_reporte_drogas_colombia_2016.pdf [visitado el 08.05.2017], p. 14.
} 
STIPPEL, Jörg; SERRANO, Juan. "La nacionalización de la lucha contra el narcotráfico en Bolivia”.

Tabla 3: Cantidad de droga incautada por tonelada, tipo de sustancia y año. ${ }^{176}$

\begin{tabular}{|c|c|c|c|c|c|c|c|c|c|c|c|c|c|c|c|c|c|}
\hline $\begin{array}{l}\text { DESCRIPC } \\
\text { ION }\end{array}$ & $\begin{array}{l}20 \\
00\end{array}$ & $\begin{array}{l}20 \\
01\end{array}$ & $\begin{array}{l}20 \\
02\end{array}$ & $\begin{array}{l}20 \\
03\end{array}$ & $\begin{array}{l}2004 \\
177\end{array}$ & $\begin{array}{l}20 \\
05\end{array}$ & $\begin{array}{l}20 \\
06\end{array}$ & $\begin{array}{l}20 \\
07\end{array}$ & $\begin{array}{l}20 \\
08\end{array}$ & $\begin{array}{l}20 \\
09\end{array}$ & $\begin{array}{l}20 \\
10\end{array}$ & $\begin{array}{l}20 \\
11\end{array}$ & $\begin{array}{l}20 \\
12\end{array}$ & $\begin{array}{l}20 \\
13\end{array}$ & 2014 & $\begin{array}{l}2015 \\
178\end{array}$ & $\begin{array}{l}201 \\
6 \\
(\mathbf{P}) \\
179\end{array}$ \\
\hline $\begin{array}{l}\text { cocaína base } \\
\text { (toneladas) }\end{array}$ & 5.0 & 4.3 & 4.7 & 6.9 & 8.2 & $\begin{array}{l}10 . \\
2\end{array}$ & $\begin{array}{l}12 . \\
8\end{array}$ & $\begin{array}{l}14 . \\
9\end{array}$ & $\begin{array}{l}21 . \\
6\end{array}$ & 22 & $\begin{array}{l}25 . \\
7\end{array}$ & $\begin{array}{l}28 . \\
4\end{array}$ & $\begin{array}{l}32 . \\
1\end{array}$ & $\begin{array}{l}20 . \\
4\end{array}$ & $\begin{array}{l}18.3 \\
180 \\
\end{array}$ & 12.7 & 8.2 \\
\hline $\begin{array}{l}\text { clorhidrato } \\
\text { de cocaína } \\
\text { (toneladas) }\end{array}$ & 0,5 & 0,3 & 0,4 & 6 & 0,5 & 1.3 & 1.3 & 2.9 & 7.2 & 4.9 & 3.4 & 5.6 & 4.2 & 1.6 & 4.1 & 8.6 & $\begin{array}{l}16 . \\
7\end{array}$ \\
\hline
\end{tabular}

Las cifras muestran que los años en que menos drogas se incautaron, coinciden con el tiempo de implementación del "Plan Dignidad" que amentó la presencia militar en la provincia del Chapare. Por otro lado, observamos que desde la "legalización" del cato de coca iniciada en 2004, las cantidades de drogas incautadas se multiplicaron. El Ministro de Gobierno de Bolivia sostuvo en 2015 que ese incremento en la incautación de drogas se debía al "modelo boliviano" que ya no reposaba en la erradicación forzosa, sino concertada con los productores. ${ }^{181}$ Las cifras oficiales parecen confirmar esta interpretación.

Pese a todo, la JIFE critica, sin diferenciar entre pasta base y clorhidrato de cocaína, que "la incautación de cocaína disminuyó de 22,3 toneladas en 2014 a 21,2 toneladas en 2015, los niveles más bajos registrados desde 2007". ${ }^{182}$ Si bien la cantidad de pasta base incautada

${ }^{176}$ Datos del INE y FELCN. Las cifras de 2000 a 2004 se encuentran en el cuadro $n^{\circ}$ 3.09.05.02 contenido en INSTITUTO NACIONAL DE ESTADÍSTICA, Anuario Estadístico 2004, La Paz: INE, 2004, en: http://inecloud.ine.gob.bo/inecloud/index.php/s/hv4IjoAsCQgeVlx ; [visitado el 13.05.2017], p. 393. Por su lado, las cifras de 2004 a 2014 se encuentran en la página web del INE en: http://www.ine.gob.bo/index.php/introduccion-6/introduccion-6 [visitado el 12.06.2017]. Las cifras de basta base y clorhidrato de cocaína incautadas del 2005 al 2015 se encuentran en la figura $\mathrm{n}^{\circ} 36$ en UNODC, Bolivia. Monitoreo de Cultivos de Coca 2015, La Paz: UNODC, 2016, en: https://www.unodc.org/documents/cropmonitoring/Bolivia/Bolivia_Informe_Monitoreo_Cultivos_Coca_2015.pdf [visitado el 08.05.2017], p. 62. Los datos relativos a los años 2015 y 2016 están disponibles en la página web del FELCN disponible en: http://www.felcn.gob.bo/R-Estadisticas.aspx [visitado el 25.02.2017].

${ }^{177}$ Las cifras de 2004 al 2006, contenidas en las tablas del INE, coinciden con aquella remetida a la CICAD. Véase CICAD; OEA, Bolivia. Evaluación del Progreso de Control de Drogas 2005-2006, 2006, en: http://www.cicad.oas.org/mem/reports/4/Full Eval/Bolivia\%20-\%20Fourth\%20Round\%20-\%20ESP.pdf [visitado el 25.02.2017], p. 25.

${ }_{178}$ Cifras según FELCN disponibles en: http://www.felcn.gob.bo/R-Estadisticas.aspx [visitado el 25.02.2017]. 179 Datos del 1 de enero hasta 31 de agosto de 2016 según el FELCN disponibles en: http://www.felcn.gob.bo/R-Est-2016.aspx [visitado el 25.02.2017].

${ }^{180}$ Esta cifra del INE coincide con la información disponible en la página de la FELCN según los datos disponibles en: http://www.felcn.gob.bo/R-Est-2014.aspx [visitado el 25.02.2017].

${ }^{181}$ Véase el artículo periodístico Página Siete, "La incautación de cocaína se triplicó en los últimos 8 años", 10 de marzo 2015, en: http://www.paginasiete.bo/nacional/2015/3/10/incautacion-cocaina-triplicoultimos-anos-49622.html [visitado el 25.02.2017].

182 JUNTA INTERNACIONAL DE FISCALIZACIÓN DE ESTUPEFACIENTES, Informe de la Junta Internacional de Fiscalización de Estupefacientes correspondiente a 2016 (E/INCB/2016/1), 2017, en: https://www.incb.org/documents/Publications/AnnualReports/AR2016/Spanish/AR2016_S_ebook.pdf

[visitado el 12.06.2017], p. 78. 
Polit. crim. Vol. 13, № 25 (Julio 2018) Art. 8, pp. 264-321.

[http://www.politicacriminal.cl/Vol_13/n_25/Vol13N25A8.pdf]

bajó, nunca antes se había incautado tanto clorhidrato de cocaína en Bolivia. ${ }^{183}$ ¿Cómo podemos explicar este cambio?

Una explicación reside en que aparentemente Bolivia se ha convertido en un "país tránsito" de cocaína. El CONALTID explica en su Estrategia 2011 a 2015, que en la gestión 2010 "del 100\% de cocaína secuestrada, 49\% correspondía a incautaciones procedentes de otros países". ${ }^{184}$ También el celebre periodista boliviano crítico del gobierno de Morales, Carlos Valverde, señala que un porcentaje importante de la droga incautada es proveniente del exterior, particularmente del Perú. ${ }^{185}$ Resalta que en los últimos años aumentó la cantidad de clorhidrato de cocaína incautada y paralelamente bajaron las incautaciones de pasta base. La explicación que ofrece es que los narcotraficantes bolivianos "resultaron ser muy avanzados tecnológicamente". Como el control de fármacos en Bolivia es deficiente, se estaría utilizando una sustancia ${ }^{186}$ que aumenta el peso y mejora el aspecto de la cocaína para el mercado internacional. Bolivia se habría convertido en el centro de cristalización de cocaína de la región. Eso explicaría la importación de pasta base y el aumento de incautaciones de clorhidrato de cocaína. Esta evolución queda corroborada en las cifras relativas a la destrucción de fábricas de pasta base y laboratorios de producción de clorhidrato y de reciclaje que analizamos a continuación.

\subsection{Número de fábricas y laboratorios de elaboración de cocaína destruidas}

\subsubsection{Fabricas destruidas}

Las estadísticas de la FELCN se refieren a "fabricas" destruidas y a "laboratorios" de cristalización y de reciclaje. Las fábricas se usan para los primeros pasos de la producción, es cuando se transforman las hojas de coca en pasta de cocaína. Según la policía boliviana con el método tradicional de producción, se usaban 300 kilos de hoja de coca para producir

${ }^{183}$ El Transnational Institute afirma a este respecto en su página web que "la JIFE ha ido asumiendo con los años un papel político que mantiene una interpretación muy estricta de las convenciones sobre drogas, juzgando a los Estados soberanos cuyas políticas toman una dirección distinta e instándolos a permanecer dentro de los límites de las convenciones. Es decir, La Junta se ha excedido en su papel de organismo de control de las convenciones de la ONU haciendo comentarios sobre cuestiones que solo son competencia de los Gobiernos nacionales.”. En: https://www.tni.org/es/publicacion/las-convenciones-de-drogas-de-la-onu\#2 [visitado el 08.05.2017].

${ }^{184}$ CONALTID, Boletín, cit. nota $\mathrm{n}^{\circ} 141$, p. 14.

185 Tras haber revelado la relación que mantenía Evo Morales con Gabriela Zapata y haber mostrado un certificado de nacimiento de un hijo que supuestamente nació de esta relación, Carlos Valverde alega haber recibido amenazas del gobierno. En consecuencia salió de Bolivia rumbo a Argentina. El escándalo mediático causado a raíz de estas revelaciones supuestamente incidió de manera decisiva en el resultado negativo del referéndum convocado para permitir la reelección de Evo Morales. Véase el artículo: El Mundo, "Huye a Argentina el periodista que denunció a Evo Morales por tráfico de influencias", 27 de junio de 2016, en: http://www.elmundo.es/america/2016/05/27/57489a59268e3e4f4a8b4584.html [visitado el 08.05.2017].

${ }^{186}$ Valverde cita aquí un reportaje que identifica a fenacetina cuyo nombre comercial sería acetofenetidina como medicamento utilizado como adulterante activo que "mejora" el producto. VALVERDE, Carlos, Territorio, poder y cocaína, Santa Cruz de la Sierra: El país, 2016, pp. 125-127 


\section{STIPPEL, Jörg; SERRANO, Juan. "La nacionalización}

de la lucha contra el narcotráfico en Bolivia".

un kilo de pasta base. Con el método actual supuestamente sólo se requieren 250 kilos para obtener el mismo resultado. ${ }^{187}$

La información disponible sobre el número de fábricas de elaboración de pasta base de cocaína destruidas, abarca el periodo de 2004 a 2016. Vemos que el 2004 se destruyeron 2.254 fábricas y el año siguiente, justo antes de que asumiera Evo Morales como presidente, $1.006 .{ }^{188}$ Desde entonces la cifra se ha multiplicado, variando entre $4.000 \mathrm{y}$ 5.000 fábricas destruidas, alcanzando un máximo de 5.922 el año 2010. La siguiente tabla muestra este evolución:

Tabla 4: Número de fábricas de elaboración de cocaína (pasta base) destruidas 2004 al 2016 por departamento. ${ }^{189}$

\begin{tabular}{|c|c|c|c|c|c|c|c|c|c|c|c|c|c|}
\hline & 2004 & 2005 & 2006 & 2007 & 2008 & 2009 & 2010 & 2011 & 2012 & 2013 & 2014 & $2015^{190}$ & $2016^{191}$ \\
\hline BOLIVIA & $\begin{array}{l}\stackrel{+}{n} \\
\text { in } \\
\text { in }\end{array}$ & $\stackrel{8}{\circ}$ & $\begin{array}{l}\stackrel{0}{0} \\
+\end{array}$ & $\begin{array}{l}0 \\
5 \\
+ \\
+\end{array}$ & $\begin{array}{l}\infty \\
\infty \\
\propto \\
\forall \\
\end{array}$ & 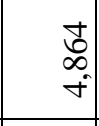 & $\begin{array}{l}\text { तै } \\
\text { जे }\end{array}$ & $\begin{array}{l}\sqrt{n} \\
\text { n} \\
n\end{array}$ & $\begin{array}{l}\tilde{f} \\
\dot{f}\end{array}$ & ले & $\begin{array}{l}8 \\
\text { m. } \\
\text { in }\end{array}$ & $\begin{array}{l}\stackrel{+}{+} \\
\stackrel{+}{+}\end{array}$ & $\begin{array}{l}6 \\
\delta \\
f\end{array}$ \\
\hline Chuquisaca & ナ & 0 & $\simeq$ & $\nabla$ & $N$ & $n$ & $m$ & 0 & 0 & 0 & $N$ & 0 & \\
\hline $\mathrm{La} \mathrm{Paz}$ & $\tilde{n}$ & $a$ & 8 & ¿̊) & $\Xi$ & $\stackrel{\wp}{ \pm}$ & $\stackrel{\infty}{n}$ & à & $\infty$ & 8 & 咅 & จे & \\
\hline Cochabamba & \begin{tabular}{l}
0 \\
\multirow{2}{\sigma}{} \\
-
\end{tabular} & $\stackrel{\infty}{\infty}$ & $\begin{array}{l}\hat{\sigma} \\
\stackrel{n}{n}\end{array}$ & $\begin{array}{l}n \\
\text { m. } \\
\text { m. }\end{array}$ & $\begin{array}{l}\stackrel{+}{\infty} \\
\stackrel{+}{+}\end{array}$ & 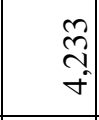 & $\begin{array}{l}\text { ふ઼ } \\
\text { ণे }\end{array}$ & $\begin{array}{l}0 \\
\stackrel{0}{+} \\
\end{array}$ & $\begin{array}{l}m \\
\infty \\
i \\
i\end{array}$ & $\stackrel{\infty}{\infty}$ & $\stackrel{m}{\stackrel{m}{i}}$ & $\begin{array}{l}\stackrel{0}{\hat{N}} \\
i\end{array}$ & \\
\hline Oruro & - & $r$ & $\stackrel{0}{0}$ & $\infty$ & i & ㄴ. & กี & \pm & $N$ & 6 & $N$ & 0 & \\
\hline Potosí & 0 & 0 & - & 0 & 0 & $\sim$ & $\stackrel{\sim}{~}$ & - & 0 & ナ & $N$ & - & \\
\hline
\end{tabular}

${ }^{187}$ Por otro lado, un documento de UNODC explica que en el Perú se están usando 100 kilos de hojas de coca más varias sustancias químicas, para producir un kilo de pasta base. UNODC, "UNODC", cit. nota no 153, p. 61. Acerca de lo expresado por la policía boliviana, véase el artículo periodístico de Página Siete, "Bolivianos y extranjeros montan laboratorios de cocaína pura", 26 de junio 2016, en: http://www.paginasiete.bo/seguridad/2016/6/26/bolivianos-extranjeros-montan-laboratorios-cocaina-pura100815.html [visitado el 08.05.2017].

${ }^{188} \mathrm{El}$ informe de UNODC indica como fuente de sus datos la FELCN, pero contempla otra cifra para el año 2005, indicando que se destruyeron 2.619 fábricas. En lo demás coinciden los datos. UNODC, Bolivia. Monitoreo de Cultivos de Coca 2015, La Paz: UNODC, 2016, en: https://www.unodc.org/documents/cropmonitoring/Bolivia/Bolivia_Informe_Monitoreo_Cultivos_Coca_2015.pdf [visitado el 08.05.2017], p. 63.

${ }^{189}$ Datos según el INE y la FELCN. Datos disponibles en la página del INE, ID Tabla: 3090527, en en http://www.ine.gob.bo/index.php/introduccion-6/introduccion-6 [visitado el 13.05.2017]. Los datos del 2015 están disponible en la página de la FELCN, en: http://www.felcn.gob.bo/R-Estadisticas.aspx [visitado el 13.05.2017].

${ }^{190}$ Datos del 2015 según FELCN, en: http://www.felcn.gob.bo/R-Estadisticas.aspx

191 La página de la FELCN no desagrega la información del 2016 por departamento, en: http://www.felcn.gob.bo/R-Est-2016.aspx [visitado el 13.05.2017]. 
Polít. crim. Vol. 13, № 25 (Julio 2018) Art. 8, pp. 264-321.

[http://www.politicacriminal.cl/Vol_13/n_25/Vol13N25A8.pdf]

\begin{tabular}{|c|c|c|c|c|c|c|c|c|c|c|c|c|c|}
\hline Tarija & 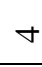 & 0 & 2 & $\stackrel{\bullet}{0}$ & $\simeq$ & $\stackrel{ \pm}{\sim}$ & \pm & $\infty$ & - & $r$ & $a$ & - & \\
\hline Santa Cruz & $\underset{\simeq}{+}$ & $n$ & $\mathbb{N}$ & $\stackrel{\infty}{\sim}$ & ৯े & $\stackrel{2}{n}$ & $\overline{\mathbb{N}}$ & స్ & $\stackrel{\text { ô }}{+}$ & $\begin{array}{l}2 \\
\infty \\
-\end{array}$ & $\begin{array}{l}\text { aे } \\
\text { i }\end{array}$ & $\stackrel{8}{+}$ & \\
\hline Beni & กี & 0 & ㄱ & 0 & mे & กี & $\stackrel{\infty}{+}$ & $\approx$ & $\simeq$ & $N$ & $\stackrel{2}{2}$ & 工 & \\
\hline Pando & & & 0 & - & - & - & 0 & 0 & 0 & 0 & 0 & 0 & \\
\hline
\end{tabular}

Las cifras muestran que las fábricas de pasta base se encuentran en su gran mayoría en los departamentos de Cochabamba y Santa Cruz. Por la cantidad de hojas que requiere el proceso de producción de la pasta base, las fábricas se encuentran normalmente cerca de los lugares de siembra. ${ }^{192}$ Desde esta perspectiva parece probable que una gran cantidad de hoja de coca producida en el Chapare, que forma parte del departamento de Cochabamba, haya sido usado para la producción de pasta base. Como el departamento de Santa Cruz colinda con el de Cochabamba, es muy probable que otra parte de la hoja de coca proveniente del Chapare se haya procesado allá. Vemos que el $98 \%$ de todas las fábricas de pasta base se concentraron el 2014 en Cochabamba y Santa Cruz, y el año siguiente este porcentaje crece un $99 \%$.

El periodista Carlos Valverde afirma que el Chapare se ha convertido en el abastecedor principal del narcotráfico en Bolivia ${ }^{193}$. No obstante vemos que ya en 2004 el $96 \%$ de las fabricas destruidas se encontraban en los departamentos de Cochabamba y Santa Cruz. El porcentaje de fábricas destruidas en el departamento de Cochabamba sobre el total de fábricas destruidas, ha disminuido en los últimos años. El incremento constate de fábricas destruidas en el departamento de Santa Cruz hasta el año 2014, muestra que está región está ganando importancia. Así que no es un desarrollo reciente que el Chapare sea el abastecedor principal del narcotráfico, por lo menos desde el 2004 la situación no ha cambiado. Igual, estas cifras aún no permiten explicar la variación en las cantidades de pasta base y clorhidrato de cocaína incautadas. Para ello podemos analizar la cantidad de laboratorios destruidos.

\subsubsection{Laboratorios destruidos}

El proceso de producción de clorhidrato de cocaína termina en los laboratorios. Es aquí donde se disuelve la pasta base, para luego ser filtrado, agregando finalmente un solvente orgánico (como acetona o ácido clorhídrico). En los datos disponibles, vemos que la

${ }^{192}$ UNODC explica que la elaboración de la pasta base de cocaína "se realiza en laboratorios construidos en zonas aledañas a los cultivos de coca, siendo indispensable disponer de corrientes de agua en el proceso de extracción del alcaloide cocaína, reciclaje de solventes, lavado de equipos y disposición de desechos del procesamiento químico de la hoja de coca”. UNODC, Making, cit. nota n 148, p. 59.

${ }^{193}$ VALVERDE, Territorio, cit. nota nº 189, pp. 150 y 155. 


\section{STIPPEL, Jörg; SERRANO, Juan. "La nacionalización} de la lucha contra el narcotráfico en Bolivia”.

cantidad de laboratorios de clorhidrato de cocaína destruidos ha crecido de manera constante. Si el año 2005 solo se destruyeron 3 laboratorios de cristalización y 2 de reciclaje, el 2016 la policía ya tenía que desmontar 68 laboratorios de cristalización y 57 de reciclaje. La siguiente tabla contempla este resultado:

Tabla 5: Destrucción de laboratorios de cristalización y reciclaje 2005 - 2016. ${ }^{194}$

\begin{tabular}{|l|l|l|l|l|l|l|l|l|l|l|l|l|}
\hline & 2005 & 2006 & 2007 & 2008 & 2009 & 2010 & 2011 & 2012 & 2013 & 2014 & 2015 & 2016 \\
\hline Lab. Cristalización & 3 & 3 & 7 & 7 & 16 & 24 & 25 & 37 & 67 & 74 & 73 & 68 \\
\hline Lab. Reciclaje & 2 & 2 & 4 & 4 & 8 & 19 & 22 & 38 & 50 & 58 & 62 & 57 \\
\hline
\end{tabular}

Vemos que en la destrucción de laboratorios de cristalización y reciclaje ha tenido un desarrollo exponencial. Una explicación sería que la policía investiga de manera más focalizada, poniendo énfasis en la búsqueda de laboratorios de clorhidrato de cocaína para luchar en contra de los grandes narcotraficantes en vez de investigar a los trabajadores y peones de las fábricas de pasta base, llamados coloquialmente "pisa-cocas". Esta explicación es cuestionable a la luz de los resultados anteriores pues la tendencia de aprehensiones por narcotráfico ${ }^{195}$ no refleja de ninguna manera la de laboratorios destruidos. Si las investigaciones serían más eficientes, el número de personas aprehendidas bajo cargos de narcotráfico debería haber incrementado. Eso no es el caso. Podemos constatar, además, que el incremento no refleja solo el porcentaje de crecimiento de la fuerza policial, sino lo supera con amplitud. Parece evidente que el rol que cumple Bolivia en el proceso regional de producción de cocaína, ha cambiado.

\footnotetext{
${ }^{194}$ Datos según FECLN y UNODC. UNODC explica que los laboratorios de reciclaje son laboratorios donde se reciclan solventes utilizados en la fabricación de clorhidrato de cocaína. UNODC, Pasta Básica de Cocaína. Cuatro décadas de historia, actualidad y desafíos, Lima: UNODC, 2013, en: https://www.unodc.org/documents/peruandecuador/Publicaciones/Publicaciones2013/LIBRO_PBC.pdf

[visitado el 13.05.2017], p. 64; UNODC, "Bolivia", cit. nota ${ }^{\circ}$ 182, p. 64, figura 39. Las cifras de 2010 a 2015 expuestas en el informe de UNODC, coinciden con la información disponible en la página institucional de la FELCN. Para el período anterior no existe información en la página, por lo que se ha recurrido a las cifras de UNODC. Cifras de 2016 según FELCN, disponible en: http://www.felcn.gob.bo/R-Est-2016.aspx [visitado el 08.05.2017].

${ }^{195}$ Las estadísticas no contemplan datos específicos sobre personas aprehendidas por fabricación de sustancias controladas (art. 47 de la Ley 1008). Parece poco probable que la FELCN no haya aprehendido a ninguna persona por fabricación, pues las cifras de fábricas destruidos son elevadas desde hace años. Como la pena prevista para el narcotráfico es de 10 a 25 años de prisión y con ello mayor que la prevista para fabricación ( 5 a 15 años), es probable que todos los posibles casos de fabricación estén contabilizados bajo "aprehensiones por narcotráfico". Esta interpretación parece clara si se toma en cuenta que el tipo penal de tráfico hace una remisión a una definición muy amplia (art. 48 párr. 2 remite al art. 33 letra m. de la Ley 1008). Según esta definición se entiende por tráfico también "todo acto dirigido o emergente de las acciones de producir, fabricar, poseer dolosamente (...) transportar". Así la conducta tipo de fabricación puede ser entendida como un "acto dirigido a la acción de fabricar". Debido a esta formulación amplia es más fácil encontrar elementos para justificar una condena por narcotráfico ya que si no se logra comprobar la fabricación, se puede fundar la condena en la posesión dolosa o el transporte u otra de las conductas de la definición. Por ello suponemos que los casos registrados como aprehensiones por narcotráfico comprenden aquellas conductas que deberían ser registrados como fabricación.
} 
En cambio, y como ya vimos, la JIFE no elabora un juicio ponderado. La JIFE ${ }^{196}$ afirma, en su último informe, que la fabricación ilícita de cocaína tiene lugar principalmente - en orden descendente - en Colombia, Perú y Bolivia. Igual constata que a su vez se encontraron laboratorios de elaboración de derivados de la hoja de coca en Argentina, Brasil, Chile y Ecuador. Lo que sorprende es que haya incongruencias en las cifras que nos ofrece ese organismo que se autodefine como independiente y "cuasi judicial". ${ }^{197}$

La JIFE indica correctamente que se han desmantelado el año 2015 un total de 73 laboratorios de fabricación ilícita de clorhidrato de cocaína en Bolivia. Vimos que además se desmantelaron este año 4.234 fábricas de pasta base y 62 laboratorios de reciclaje. Ambas cifras no las menciona la JIFE. En cambio para el mismo año, ese organismo internacional indica que en Colombia fueron destruidos 3.850 laboratorios de fabricación ilícita de clorhidrato de cocaína. ${ }^{198}$ Debemos señalar que la información de la JIFE es incorrecta si la cruzamos con otras fuentes. El Observatorio de Drogas de Colombia, un organismo estatal, señala que el año 2015 se desmantelaron 3.591 infraestructuras para la extracción de base de coca, que equivaldría a las fábricas destruidas en el caso boliviano, y 230 de refinamiento de clorhidrato de cocaína. En consecuencia, en 2015 en Colombia no se destruyeron 3.850 laboratorios de fabricación ilícita de clorhidrato de cocaína, sino solo 230. ${ }^{199}$

En un informe de un organismo internacional a cargo de supervisar el cumplimiento de los distintos convenios de lucha contra el narcotráfico, ese error numérico induce a pensar que los esfuerzos del Estado Plurinacional de Bolivia en la lucha contra el narcotráfico son mínimos en comparación con la labor de las autoridades colombianas. En cambio, las cifras reales aquí analizadas permiten llegar a la conclusión contraria. Estas imprecisiones ponen en duda la supuesta independencia de la JIFE.

\subsection{Población penal detenida por narcotráfico}

Como último punto en nuestro análisis estadístico, observamos una importante disminución de las personas recluidas por delitos tipificados en la Ley 1008 en relación al conjunto de la población reclusa. Vimos que el número total de personas aprehendidas por delitos tipificados en la Ley 1008 bajó considerablemente en los últimos años, esta baja todavía no se refleja en la cantidad total de personas recluidas en las cárceles bolivianas. El número más elevado de personas privadas de libertad, tanto en cifras totales como porcentuales, se dio al inicio del presente siglo (4.753 equivalente al 58,5 \%). Desde entonces hasta 2010, la cifra total de personas recluidas por narcotráfico bajó aproximadamente a niveles que van de 2.500 a 3.100. En esta década el número total de personas recluidas por delitos relacionados al narcotráfico subió nuevamente a casi 4.000. No obstante el porcentaje de personas encarcelados por delitos de la Ley 1008 en relación al total de la población

\footnotetext{
${ }^{196}$ Creada por el artículo 1 numeral 1 a. de la Convención Única de Estupefacientes de 1961.

${ }^{197}$ Véase la presentación en la página institucional de la JIFE en: https://www.incb.org/incb/es/about.html [visitado el 08.05.2017].

198 JUNTA INTERNACIONAL DE FISCALIZACIÓN DE ESTUPEFACIENTES, Informe, cit. nota nº 185, p. 78.

${ }^{199}$ OBSERVATORIO DE DROGAS DE COLOMBIA, Reporte, cit. nota nº 177, p. 91.
} 
STIPPEL, Jörg; SERRANO, Juan. "La nacionalización de la lucha contra el narcotráfico en Bolivia".

encarcelada disminuye constantemente de más de la mitad (58,5\%) en 2000, a una cifra un poco menor a un quinto $(19,8 \%)$ en junio 2016.

Tabla 6: Población penal (condenados y procesados) por narcotráfico. ${ }^{200}$

\begin{tabular}{|c|c|c|c|c|c|c|c|c|c|c|c|c|c|c|c|c|c|}
\hline $\begin{array}{l}\text { DESCRIPC } \\
\text { ION }\end{array}$ & $\begin{array}{l}200 \\
0\end{array}$ & $\begin{array}{l}200 \\
1\end{array}$ & $\begin{array}{l}200 \\
2\end{array}$ & \begin{tabular}{|l}
200 \\
3
\end{tabular} & \begin{tabular}{|l}
200 \\
4 \\
$(2)$ \\
\end{tabular} & $\begin{array}{l}200 \\
5\end{array}$ & \begin{tabular}{|l}
200 \\
6 \\
$(3)$ \\
\end{tabular} & $\begin{array}{l}200 \\
7\end{array}$ & \begin{tabular}{|l|}
200 \\
8
\end{tabular} & $\begin{array}{l}200 \\
9\end{array}$ & \begin{tabular}{|l|}
201 \\
0
\end{tabular} & $\begin{array}{l}201 \\
1\end{array}$ & $\begin{array}{l}201 \\
2\end{array}$ & \begin{tabular}{|l|}
201 \\
3
\end{tabular} & \begin{tabular}{|l|}
201 \\
4 \\
$(p)$ \\
\end{tabular} & $\begin{array}{l}2015 \\
201\end{array}$ & 2016 \\
\hline BOLIVIA & $\underset{\infty}{\stackrel{ \pm}{\sim}}$ & 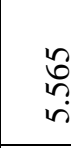 & 今. & 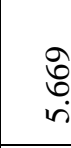 & ๙̊ & م̊ & $\stackrel{\bar{r}}{i}$ & $\underset{\sim}{\infty}$ & $\stackrel{\substack{f \\
r}}{r}$ & $\begin{array}{l}0 \\
0 \\
\infty \\
\infty\end{array}$ & $\begin{array}{l}\stackrel{8}{o} \\
+ \\
\sigma\end{array}$ & $\begin{array}{l}\curvearrowleft \\
\approx \\
=\end{array}$ & $\begin{array}{l}\stackrel{N}{N} \\
\stackrel{ \pm}{ \pm}\end{array}$ & $\begin{array}{l}\frac{n}{7} \\
\dot{ \pm}\end{array}$ & 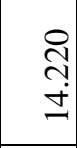 & $\begin{array}{l}n \\
\tilde{n} \\
\check{n}\end{array}$ & $\begin{array}{l}0 \\
\ddot{0} \\
\dot{n}\end{array}$ \\
\hline $\begin{array}{l}\text { Narcotráfic } \\
\text { o }\end{array}$ & $\stackrel{\Re}{\stackrel{n}{r}}$ & 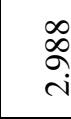 & $\begin{array}{l}\mathrm{N} \\
\infty \\
i\end{array}$ & $\stackrel{n}{n}$ & $\begin{array}{l}\mathscr{2} \\
\infty \\
\text { i }\end{array}$ & $\begin{array}{l}\overline{0} \\
\dot{m}\end{array}$ & $\begin{array}{l}\infty \\
\stackrel{\infty}{0} \\
\dot{r}\end{array}$ & $\begin{array}{l}+ \\
\infty \\
i\end{array}$ & $\begin{array}{l}\stackrel{2}{2} \\
\text { ì }\end{array}$ & $\begin{array}{l}\text { กี } \\
\text { ते }\end{array}$ & $\underset{\vec{J}}{i}$ & 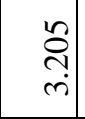 & $\begin{array}{l}\infty \\
\stackrel{\infty}{n} \\
\dot{n}\end{array}$ & ळે & 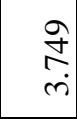 & $\begin{array}{l}0 \\
\infty \\
i \\
i\end{array}$ & $\hat{\hat{a}}$ \\
\hline$\%$ & $\begin{array}{l}n \\
\infty \\
\infty\end{array}$ & ñ & कृ & $\stackrel{+}{\dot{f}}$ & $\stackrel{0}{\dot{f}}$ & $\stackrel{b}{\dot{f}}$ & $\stackrel{\infty}{\oplus}$ & $\frac{\vec{m}}{m}$ & $\begin{array}{l}0 \\
\hat{n}\end{array}$ & $\stackrel{\sim}{\approx}$ & $\overrightarrow{\mathrm{i}}$ & $\begin{array}{l}0 \\
\infty \\
i\end{array}$ & 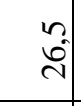 & $\stackrel{2}{\stackrel{\sim}{N}}$ & t. & in & $\begin{array}{l}\infty \\
\stackrel{\infty}{\Omega}\end{array}$ \\
\hline $\begin{array}{l}\text { Personas en } \\
\text { prisión } \\
\text { preventiva }\end{array}$ & $\begin{array}{c}n \\
\dot{v} \\
i\end{array}$ & 竎 & ๙ે & 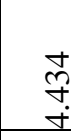 & 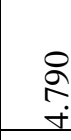 & ¿े. & त̂ & $\begin{array}{l}\mathbb{1} \\
\stackrel{n}{n} \\
\end{array}$ & 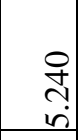 & $\begin{array}{l} \pm \\
\vdots \\
0 \\
\end{array}$ & ָุ. & $\begin{array}{l}n \\
\tilde{a} \\
a\end{array}$ & 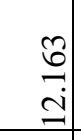 & $\begin{array}{l}\text { ڤ. } \\
\Xi\end{array}$ & $\begin{array}{l}\stackrel{N}{0} \\
\stackrel{\Xi}{=}\end{array}$ & & $\begin{array}{l}\stackrel{N}{N} \\
\stackrel{0}{0}\end{array}$ \\
\hline $\begin{array}{l}\text { \% de presos } \\
\text { preventivos }\end{array}$ & சே. & $\frac{1}{6}$ & $\infty$ & $\underset{\infty}{\infty}$ & $\hat{i}$ & I & $\stackrel{+}{ \pm}$ & $\infty$ & ?. & ลี & ก & \begin{tabular}{|c|} 
\\
$\dot{\infty}$ \\
$\infty$
\end{tabular} & $\begin{array}{l}1 \\
1 \\
\infty \\
\infty\end{array}$ & 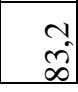 & $\frac{9}{\infty}$ & & $\stackrel{\infty}{6}$ \\
\hline
\end{tabular}

La disminución de la población recluida por narcotráfico entre 2014 y 2015 (de 3.749 a 2.786) tiene su explicación en un indulto presidencial. El Decreto Presidencial $\mathrm{n}^{\circ} 2131 \mathrm{del}$ 1 de octubre 2014 beneficia entre otros a personas condenadas en el marco de la Ley $\mathrm{N}^{\circ}$ 1008 "que hayan cumplido una cuarta parte de la condena privativa de libertad". ${ }^{203}$ En total se beneficiaron 1.232 personas de ese indulto, ${ }^{204}$ parte de ellos condenados por la Ley 1008.

A su vez podemos explicar la leve baja de los números totales de personas recluidas por narcotráfico en los años posteriores al 2001, con la derogación de la parte procesal de la Ley 1008 por el nuevo Código de Procedimiento Penal que entró en vigencia a mediados del 2001. ${ }^{205}$ Probablemente el número de personas recluidas de manera preventiva por la Ley 1008, bajó en el mismo tiempo. Esta hipótesis se ve reforzada si se toma en cuenta el número de personas aprehendidas por delitos relacionados a la Ley 1008. En contra al

\footnotetext{
${ }^{200}$ Datos de la Dirección General de Régimen Penitenciario citados por el INE disponibles en su página web en: http://www.ine.gob.bo/indice/EstadisticaSocial.aspx?codigo=30904 [visitado el 25.02.2017].

${ }^{201}$ Cifra de junio 2015 según la DIRECCIÓN GENERAL DE RÉGIMEN PENITENCIARIO, Plan Estratégico Nacional de la Dirección General de Régimen Penitenciario 2016-2020, 2016, documento interno no publicado, pp. 17 y 21.

${ }^{202}$ Cifras de julio 2016 según los datos contenidos en Oficio de la Dirección General de Régimen Penitenciario (DGRP-EST Nro. 038/16) del 17 agosto 2016, documento interno no publicado.

203 Art. 2 párr. I. letra j. del Decreto Presidencial n²131 del 1 de octubre 2014 disponible en: http://gacetaoficialdebolivia.gob.bo/index.php/normas/descargar/152834 [visitado el 25.02.2017].

${ }^{204}$ Según el "Plan Estratégico Nacional de la Dirección General de Régimen Penitenciario 2016 -2020", p. 23, Documento interno no publicado.

${ }^{205}$ Sexto disposición final numeral 1 de la ley No. 1970.
} 
Polit. crim. Vol. 13, № 25 (Julio 2018) Art. 8, pp. 264-321.

[http://www.politicacriminal.cl/Vol_13/n_25/Vol13N25A8.pdf]

desarrollo de la cifra total de personas recluidas, la cifra total de aprehensiones experimentó un constante aumento de 2000 a 2013, año en que vuelve a disminuir. Esto indica el aumento de las detenciones realizadas por la policía finalmente no implica un encarcelamiento automático. Sería un resultado positivo desde la perspectiva de la protección de la presunción de inocencia.

Sorprende que en los últimos 15 años, el porcentaje de personas recluidas por la Ley 1008 en comparación con el resto de los delitos, haya disminuido por más que la mitad (de 58,5 $\%$ el 2000 a 19,8 \% en 2016). Una interpretación sería que las cifras demuestran un cambio de enfoque de la política criminal. La policía ya no estaría concentrando sus mayores esfuerzos en perseguir delitos relacionados al narcotráfico, sino hubiera comenzado a poner énfasis en investigar otros delitos de la delincuencia común.

El Departamento de Estado de Estados Unidos ofrece otra interpretación. Manifiesta su preocupación ante el hecho de que el número de personas condenadas por narcotráfico se ha mantenido estancado en varios años y que en relación al conjunto de detenciones no se haya incrementado. El Departamento de Estado critica así el funcionamiento del sistema judicial boliviano, que debido a su inefectividad permite el vencimiento de los plazos y genera así impunidad. ${ }^{206}$

Ambas explicaciones aportan al entendimiento del fenómeno. Es cierto que el sistema judicial es ineficiente. Así lo demuestra la tasa de prisión preventiva que en 2012 alcanzó el $85 \%$. No obstante, se trata de un problema transversal que afecta a todas las personas detenidas y no solo a aquellos detenidos por delitos relacionados a la Ley 1008 . No estamos frente a un posible privilegio otorgado a narcotraficantes, sino vemos el resultado de una deficiencia, ya crónica, que afecta a todas las personas sometidas al sistema judicial boliviano.

En cambio, la disminución de la relevancia relativa de los delitos de la Ley 1008 en relación al resto de la criminalidad, es algo novedoso. Vimos cómo, hasta antes del cambio del enfoque la política criminal boliviana, entre un 43 y $58 \%$ de las personas estaban recluidas por delitos relacionados a la Ley 1008. Hoy esta cifra llega a un $20 \%$, con ello se aproxima a la realidad de otros países de la región.

Podemos apreciar que en Argentina se contabiliza el $11 \%$ (7.862) de personas recluidas por infracciones a la ley de estupefacientes (Ley 23.737) sobre el total de la población encarcelada (71.464 en 2015). ${ }^{207}$ Por su lado, Chile cuenta un 16, $3 \%$ (9.763 de 60.078 en

\footnotetext{
${ }^{206}$ El Departamento de Estado afirma en este sentido: "While Bolivia continues to make drug seizures and arrests of implicated individuals, the Bolivian judicial system is not adequately processing these cases to completion. Bolivian law requires that an arrestee be formally charged within 18 months of arrest. An overwhelming majority of the incarcerated population in Bolivia, however, has not been formally charged in accordance with Bolivian law. The number of individuals who have been convicted and sentenced on drug charges in Bolivia has remained stagnant over the last several years and has not increased in proportion to the number of arrests." UNITED STATES DEPARTMENT OF STATE, International, cit. nota nº 121, p. 13.

${ }^{207}$ Las estadísticas del Sistema Nacional de Estadísticas de Ejecución de la Pena (SNEEP), contemplan cifras diferenciadas por cantidad de "menciones" de un determinado delito. La cifra que nosotros ocupamos es la
} 


\section{STIPPEL, Jörg; SERRANO, Juan. "La nacionalización de la lucha contra el narcotráfico en Bolivia".}

2014) de recluidos y recluidas por delitos relacionados a la Ley de Drogas (Ley 20.000). ${ }^{208}$ En Colombia, en 2016, un 13,2 \% (24.267 de 183.411) de los presos lo está por tráfico, fabricación o porte de estupefacientes; ${ }^{209}$ y, en Perú, en 2016, un 22,3\% por los distintos delitos relacionados al tráfico de drogas. ${ }^{210}$

Vemos que hoy el porcentaje de encarcelados por delitos relacionados a drogas en Bolivia, se ubica entre aquel que ostentan Perú y Colombia, los otros países productores de coca de la región. Ya no parece ser la única prioridad de la política criminal, sino una más entre otras.

\section{Conclusiones}

\section{1. El problema no son las drogas, sino la política de control de drogas}

El camino recorrido por Bolivia previo a la nacionalización de la política de drogas muestra que el problema no son las drogas, sino la política de control de drogas. La estrategia de control de drogas en Bolivia pretendía eliminar la producción y oferta de drogas mediante la prohibición con la Ley 1008 a partir de acciones de represión policial y militar. Estas medidas fueron acompañadas de una internacionalización de la "lucha" con el apoyo de Estados Unidos y la militarización de la represión. Como vimos en el análisis de las estadísticas, el impacto práctico de las políticas de control fue la saturación judicial y el hacinamiento carcelario pues más que la mitad de la población recluida tenía cargos relacionados a la Ley $1008 .^{211}$ La sobrepoblación carcelaria era, a su vez, producto de una

donde se menciona $\mathrm{n}$ primer lugar los delitos relacionados a la ley de estupefacientes. SISTEMA NACIONAL DE ESTADÍSTICAS DE EJECUCIÓN DE LA PENA, Informe Anual 2015, Buenos Aires: Ministerio de Justicia y Derechosa Humanos, http://www.jus.gob.ar/media/3191517/informe sneep argentina 2015.pdf [visitado el 08.05.2017], p. 23.

${ }^{208}$ SUBDIRECCIÓN TÉCNICA DE LA GENDARMERÍA DE CHILE, Informe de Gestión 2014, Santiago de Chile. SISTEMA NACIONAL DE ESTADÍSTICAS DE EJECUCIÓN DE LA PENA, 2015, en: https://html.gendarmeria.gob.cl/doc/20141105 memoria_sdt/Memoria_SDT_2014.pdf [visitado el 08.05.2017], p. 23.

${ }^{209}$ INSTITUTO NACIONAL PENITENCIARIO Y CARCELARIO, Informe Estadístico, Bogotá: INPEC, Enero 2016 ,

http://www.inpec.gov.co/portal/page/portal/Inpec/Institucion/Estad\%EDsticas/Estadisticas/Informes\%20y\%2 0Boletines\%20Estad\%EDsticos/01\%20INFORME\%20ENERO\%202016_pdf [visitado el 08.05.2017]; INSTITUTO NACIONAL PENITENCIARIO, Informe Estadístico Penitenciario, Lima: INE, Enero 2016, en: http://www.inpe.gob.pe/pdf/enero_2016.pdf [visitado el 08.05.2017], p. 38.

${ }^{210}$ El 10,1\% (7.773 de 77.298) por tráfico ilícito de drogas, un 5,7 \% (4.390) adicionales por tipos agravados de tráfico ilícito, un 4,5\% (3.486) por promoción o favorecimiento al tráfico y un $2 \%$ (1.568) por microcomercialización o micro-producción). INSTITUTO NACIONAL PENITENCIARIO, Informe, cit. nota $\mathrm{n}^{\circ}$ 214, p. 27.

${ }^{211}$ El desarrollo coincide con un argumento entregado por Rosa del Olmo, cuando dice que la actual guerra contra las drogas, según los argumentos de los antiprohibicionistas, produce el hacinamiento del sistema judicial que no puede ser respondido con los recursos disponibles. DEL OLMO, ¿Prohibir o domesticar?, cit. nota $\mathrm{n}^{\circ}$ 6, p. 119. En el caso de España, Diéz Ripollés destaca que "el 40\% de todas las sentencias emanantes de la jurisdicción penal española están relacionadas con la criminalidad vinculada con las drogas." Resalta que "dentro de ese $40 \%$, el $40 \%$ tiene que ver con drogas ilegales, mientras que el restante $60 \%$ está relacionado con el consumo de alcohol - en concreto, delitos contra la seguridad del tráfico. El porcentaje de sentencias relacionadas con drogas ilegales es mayor en aquellos órganos jurisdiccionales competentes para el 
legislación que en materia de drogas no permitía un debido proceso, ignorando garantías constitucionales, como el derecho a la defensa y la presunción de inocencia. Podemos afirmar por tanto que, en materia de drogas, en Bolivia se socavaron sistemáticamente los derechos civiles en nombre de la aplicación de la Ley 1008.

Desde la perspectiva institucional, Tellería y Gonzáles concluyen que el impacto de la política antidroga de 1985 a 2005 no solo consistía en la pérdida de soberanía en materia de seguridad, sino además en un proceso sistemático de desinstitucionalización de las Fuerzas Armadas y la policía. ${ }^{212}$ En base al presente estudio, podemos completar esta tesis añadiendo a la lista de instituciones que han sufrido un proceso de debilitamiento al poder judicial y el sistema carcelario. Todo ello, va de suyo, no hizo más que socavar la legitimidad del proceso de transición y consolidación democrática abriendo una ventana de oportunidad para la irrupción nuevos actores políticos, que Álvaro García Linera calificó como "la potencia plebeya", ${ }^{213}$ tal y como hemos visto más arriba.

Desde la perspectiva cuantitativa, vemos que los primeros afectados de esta política no fueron los narcotraficantes sino los pequeños productores de la hoja de coca. En la época de máxima represión militar, la cantidad de droga incautada fue mínima en comparación con las toneladas decomisadas desde que se cambió el enfoque de la política criminal en el gobierno de Mesa Gisbert. ${ }^{214}$ Desde entonces la prohibición seguida de medidas de erradicación y represión en lugar de reducir la oferta de droga, provocaron un incremento de la violencia ejercida contra la población. En otras palabras, como en cada guerra, la guerra contra las drogas provoca más "víctimas colaterales" que enemigos "eliminados". 215

\subsection{La "guerra contra las drogas" alimentó el soberanismo}

Uno de los impactos más tangibles de casi treinta años de aplicación de la Ley 1008 y con ello del empleo decidido del derecho penal en el control del tráfico y consumo de drogas en Bolivia, ha sido el aumento de los sentimientos antinorteamericanos. El tema de fondo, la lucha contra la droga y drogadicción, ha sido desplazado por discusiones sobre intereses geopolíticos y soberanía nacional.

Rosa del Olmo ya advertía de todo esto al inicio de la década de los 1990 que la guerra contra las drogas únicamente había sido exitosa en aumentar los sentimientos

enjuiciamiento en primera o segunda instancia de delitos más graves". DIÉZ RIPOLLÉS, "El control”, cit. nota $\mathrm{n}^{\circ} 9$, pie de página ${ }^{\circ} 13$.

212 TELLERÍA; GONZÁLES, Hegemonía, cit. nota nº 19, p. 200.

${ }^{213}$ GARCÍA LINERA, Álvaro, La potencia plebeya. Acción colectiva e identidades indígenas, obreras y populares en Bolivia, Buenos Aires: CLACSO, 2009, p. 423 y s.

${ }^{214}$ TELLERÍA; GONZÁLES, Hegemonía, cit. nota nº 19, p. 198.

${ }^{215}$ Coletta A. Youngers analiza los daños colaterales de las políticas estadounidenses antidrogas afirmando que el principal perjudicado son las instituciones democráticas, especialmente en el ámbito local. YOUNGERS, Coletta A., "Los daños colaterales de la "guerra contra las drogas" impulsada por Estados Unidos", en MORALES VITERI, Juan Pablo; PALADINES, Jorge Vicente (eds.), Entre el control social y los derechos humanos. Los retos de la política y la legislación de drogas - Homenaje a Juan Bustos Ramírez, Quito: Ministerio de Justicia y Derechos Humanos, 2009, pp. 217-242, p. 222. 


\section{STIPPEL, Jörg; SERRANO, Juan. "La nacionalización de la lucha contra el narcotráfico en Bolivia”.}

antinorteamericanos. ${ }^{216}$ Sentimientos que surgieron no únicamente en actores políticos radicales sino incluso en sectores conservadores, tal y como sucede en Bolivia donde vemos como actores políticos situados en la oposición al gobierno de Evo Morales alimentan esta tendencia criticando abiertamente las injerencias estadounidenses y sus efectos contraproducentes. ${ }^{217}$

Estas posiciones son compartidas por muchos académicos a nivel internacional. Diéz Ripollés percibe que la política prohibicionista de drogas todavía desempeña un papel fundamental dentro de los objetivos geoestratégicos de los Estados Unidos de América. ${ }^{218}$ El autor sostiene que bajo el pretexto de la necesaria expansión de los principios del derecho internacional, se permitía mantener agentes estatales permanentes de la DEA en otros países, y en caso de rechazo, se permitía adoptar represalias comerciales certificaciones - en contra de los Estados más débiles. ${ }^{219}$ Este tipo de injerencia alcanzó su máxima expresión con la invasión de Panamá 20 de diciembre de 1989, uno de los ejemplos más ilustrativos de cómo tras la promoción internacional de la protección de la salud se esconden en realidad intereses geopolíticos. ${ }^{220}$

El presente estudio demuestra como la cooperación internacional en la lucha contra las drogas, prevista en las convenciones internacionales, ha sido instrumentalizada para justificar acciones militares de los Estados Unidos en territorio boliviano. Por todo ello, en nuestra opinión, es necesario sincerar los discursos por parte de los Estados implicados. Las presiones de Estados Unidos hoy ya no son argumento suficiente para mantener una política prohibicionista. Bolivia, con legalización de la hoja de coca, y Uruguay y varios Estados de los Estados Unidos - Alaska, California, Colorado, Massachusetts, Nevada, Oregón y Washington - con la legalización del uso recreacional de la marihuana, han mostrado que otra política es posible. ${ }^{221}$ Urge por tanto reenfocar la discusión para debatir

${ }^{216}$ DEL OLMO, ¿Prohibir o domesticar?, cit. nota $\mathrm{n}^{\circ}$ 6, p. 66.

${ }^{217}$ El ex presidente Mesa Gisbert describe la "insoportable asfixia” que Estados Unidos había provocado a los gobiernos democráticos de 1985 a 2003 que les habían forzado a "un imposible camino en una lucha absurda contra el narcotráfico", que obligó a los gobiernos "a acciones de represión desmesurada". Mesa Gisbert caracteriza a la DEA como "un superpoder dentro del país". Mesa Gisbert, Bolivia, cit. nota n 17 , p. 64. Desde una posición pro gubernamental, Tellería y Gonzáles ven en la "inflexible política antinarcóticos" un mecanismo "de control y dominio territorial” de Estados Unidos sobre Bolivia. TELLERÍA; GONZÁLES, Hegemonía, cit. nota $\mathrm{n}^{\circ}$ 19, p. 287.

218 Juan Bustos Ramírez afirma igualmente que en "la década de los 80, del Presidente Reagan, ha sido la década de la guerra contra el narcotráfico justificada por la seguridad nacional, y basada en la salvación moral, cultural, política y económica de la civilización cristiano occidental. Guerra que se ve prolongada y aumentada en la década del noventa con la presidencia de Bush. Es la nueva guerra de cien años o la nueva cruzada, que une a todos y como nunca permite el control de todos." BUSTOS RAMÍREZ, Juan, CocaCocaína, cit. nota $\mathrm{n}^{\mathrm{o}} 72$, p. 125.

${ }^{219}$ DIÉZ RIPOLLÉS, “El control”, cit. nota n 9. A su vez Rosa del Olmo criticaba que "si América Latina no estuviera en tan terrible situación económica, no tendría que obedecer los requerimientos del gobierno de Estados Unidos que amenaza con cortar la asistencia económica si nuestros países no siguen su política de drogas”. DEL OLMO, ¿Prohibir o domesticar?, cit. nota nº 6, p. 65.

${ }^{220}$ Sobre el caso colombiano véase GARCÍA PULGARÍN, Alex, "Narcotráfico en Colombia. Un problema creado en otra parte, importado y asumido como propio", Estudios de Derecho, vol. 67 n¹49, 2010, pp. 262281 , p. 270.

${ }^{221}$ Sobre las experiencias de los estados de Washington y Colorado en regular legalmente el mercado del cannabis, véase TRANSNATIONAL INSTITUTE, Auge, cit. nota n ${ }^{\circ}$, pp. 52-56. Sobre el caso uruguayo, Guillermo Garat analiza la aprobación de la Ley 19.172 de regulación y control del cannabis. GARAT, 
Polít. crim. Vol. 13, № 25 (Julio 2018) Art. 8, pp. 264-321.

[http://www.politicacriminal.cl/Vol_13/n_25/Vol13N25A8.pdf]

sobre qué drogas perjudican la salud pública y qué estrategias sirven para enfrentar esta problemática.

\subsection{Las Convenciones Internacionales deben ser modificadas}

El caso boliviano muestra que las convenciones internacionales requieren de modificaciones que vayan más allá de la reserva para el uso de la hoja de coca incorporada a la Convención Única de 1961. En los últimos años la discusión sobre la necesaria modificación de las Convenciones Internacionales ha ganado a promotores. Los más conocidos se reúnen en la Comisión Global de Políticas de Drogas, entre ellos el ex secretario general de Naciones Unidas Kofia Annan los ex presidentes de Chile y México Ricardo Lagos y Ernesto Zedillo y el premio nobel de literatura Mario Vargas Llosa, entre otros. En la presentación de su informe de 2014 piden "a los tomadores de decisiones que rompieran con el tabú vigente desde hace cincuenta años y conversaran sobre maneras más humanas y efectivas para manejar las drogas". ${ }^{222}$ El grupo ha seguido evolucionando en sus planteamientos. El informe de 2016 pretende entregar un nuevo enfoque para la descriminalización. ${ }^{223}$ La propuesta del grupo ante esta problemática, no es la descriminalización total. Abogan a favor de la descriminalización de la posesión de sustancias para el uso personal y para la implementación de alternativas para el castigo de los "actores de baja escala en el narcotráfico", pues opinan que "muchas de estas personas están involucradas en el tráfico no violento y deben hacerlo para aliviar su severa

Guillermo, El camino. Cómo se reguló el cannabis en Uruguay según sus actores políticos y sociales, Montevideo: Friedrich Ebert Stiftung, Junta Nacional de Drogas, 2014, en: http://library.fes.de/pdffiles/bueros/uruguay/11201.pdf [visitado el 13.05.2017], pp. 95 a 101.

${ }^{222}$ GLOBAL COMMISSION ON DRUG POLICY, Asumiendo el control: Caminos hacia políticas de drogas eficaces, Global Commission on Drug Policy, 2014, https://static1.squarespace.com/static/53ecb452e4b02047c0779e59/t/5568b6a9e4b0867018e16784/14329258 65061/AF_global_comission_Espanhol_FINAL.pdf [visitado el 08.05.2017], p. 6.

${ }^{223} \mathrm{La}$ mesa directiva del grupo parte de la premisa que un enfoque punitivo "mina fundamentalmente la relación del individuo y el Estado, generando que muchos ciudadanos se vean en la necesidad de incumplir leyes ilógicas sobre drogas". Lamenta que muchos gobiernos compartan una meta "tanto ingenua como peligrosa" consagrada en las Convenciones internacionales que es tener un mundo "libre de drogas" o un "mundo libre del abuso de las drogas". Los ex jefes de estado, intelectuales y ex autoridades internacionales explican que ese objetivo es ingenuo, pues la prohibición "ha tenido un bajo - o nulo - impacto en los índices del uso de las sustancias, con el número de consumidores incrementando casi un 20\% entre 2006 y 2013 ”. Ven el objetivo como peligroso, pues la prohibición "alimenta las ejecuciones y el encarcelamiento masivo... aviva la propagación de los virus transmitidos por vía sanguínea, impulsa las violaciones a derechos humanos de aquellas personas que usan y suministran drogas al igual de los de aquellas que no consumen, y contribuye a la existencia de muertes relacionadas con drogas...". El grupo propone que los gobiernos nacionales deben "liberarse urgentemente de las restricciones de este arcaico y punitivo marco legal." Concluyen que mientras que "las sustancias sean consideradas como malvadas, y por lo tanto, sean criminalizadas, éstas continuarán en las manos de los criminales". GLOBAL COMMISSION ON DRUG POLICY, Avanzando la reforma de la política de drogas: Un nuevo enfoque para la descriminalización, Global Commission on Drug Policy, 2016, en: http://www.globalcommissionondrugs.org/wp-content/uploads/2016/11/GCDP-Report-2016_ES.pdf [visitado el 08.05.2017], pp. 8 y s. 


\section{STIPPEL, Jörg; SERRANO, Juan. "La nacionalización de la lucha contra el narcotráfico en Bolivia".}

marginación socioeconómica". ${ }^{224}$ La implementación de estas propuestas necesariamente tendría que pasar por una modificación de las Convenciones internacionales.

También a nivel regional latinoamericano varios países han abogado a favor de un cambio paradigmático en la lucha contra la droga. Este desarrollo no ha pasado desapercibido por la JIFE. En su último informe la Junta nota que en América del Sur habían continuado los debates sobre la revisión de las políticas relativas a las drogas, especialmente en lo relativo a la legalización y regulación del cannabis con fines médicos y no médicos. Pero todo eso en la percepción de la JIFE ha pasado "mientras que la región ha seguido viéndose afectada por el cultivo ilícito y el tráfico de drogas a gran escala". Por ello, la Junta "una vez más" se ve obligada a "señalar a la atención de todos los Gobiernos que las medidas que permiten la utilización del cannabis con fines no médicos infringen las disposiciones de los tratados de fiscalización internacional de drogas". A su vez la JIFE “desea señalar a la atención de todos los Gobiernos la posición que ya había transmitido de que el cultivo personal de cannabis con fines médicos es incompatible con la Convención de 1961 (...) porque exacerba el riesgo de desviación". ${ }^{225} \mathrm{El}$ informe puede ser interpretado como una suerte queja y acusación dirigidas a alumnos díscolos.

La OEA podría responder, en nombre de los gobiernos de la región, con los consensos plasmados en su Plan de Acción Hemisférico sobre Drogas para los años 2016 al 2020. ${ }^{226}$ El plan estipula la necesidad de compilar y usar evidencia como base para la formulación y actualización de las políticas y/o estrategias nacionales sobre drogas (acción 2.1). A su vez pide que los estados evalúen la viabilidad de la aplicación de medidas alternativas al encarcelamiento para los delitos menores relacionados con las drogas (Acción 5.1), alentando reformas legales que promuevan la proporcionalidad de las penas para los delitos menores relacionados con drogas (acción 7.2).

Habría que indagar con los expertos de la JIFE, ¿qué evidencia existe que la legalización del cannabis produce algún peligro para alguno de los bienes jurídicos supuestamente resguardados por las convenciones? A pesar de todos los argumentos posibles, parece descontextualizado que los Estados tengan que justificarse, ante un organismo internacional, por estas medidas adoptadas en su política criminal. No tienen la relevancia necesaria, aquí hablamos del posible desvío de unas plantas de cannabis, como para ameritar un monitoreo internacional y una crítica repetida de 13 expertos internacionales. Existen otras problemáticas que preocupan mucho más a las sociedades latinoamericanas. Una de ellas es el hacinamiento carcelario producto, entre otras, del castigo desproporcional en materia de drogas.

El argumento no es la falta de importancia coyuntural, sino la ausencia de una necesidad social del castigo de ciertas conductas tipificadas en las convenciones. En efecto, consideramos, como el criminólogo italiano Alessandro Barrata, que "la ley penal es un

\footnotetext{
${ }^{224}$ GLOBAL COMMISSION ON DRUG POLICY, Avanzando, cit. nota no 227 , pp. 9 y 35 .

${ }^{225}$ JUNTA INTERNACIONAL DE FISCALIZACIÓN DE ESTUPEFACIENTES, Informe, cit. nota ${ }^{\circ} 185$, p. 73-77.

226 CICAD; OEA, Plan de Acción Hemisférico sobre Drogas, 2016-2020, 2016 en: http://www.cicad.oas.org/mem/Activities/PoA/PoA-Version_Final-ESP.pdf [visitado el 25.02.2017].
} 
acto solemne de respuesta a los problemas sociales fundamentales que se presentan como generales y duraderos en una sociedad". ${ }^{227}$ La desviación de plantas de cannabis de su destino médico a otro, por poner un ejemplo, no sería compatible por tanto a nuestro parecer en esta caracterización de la ley penal. Por todo ello, consideramos necesario revisar de manera exhaustiva todo el articulado de las convenciones evaluando qué aporta cada una de sus normas a la solución de problemas de la comunidad internacional que sean verdaderamente fundamentales, generales y duraderos.

A pesar de todas las críticas al impacto negativo que ha tenido "la guerra contra las drogas", aún no se ha llegado a un consenso para dejar atrás el prohibicionismo como enfoque principal. En este sentido, el documento final de la Asamblea General de las Naciones Unidas sobre el problema mundial de las drogas de 2016 muestra la resistencia al cambio. Haciendo caso omiso a las críticas y las alternativas conocidas por países como Bolivia, una de las recomendaciones del documento final es "aumentar la cooperación a todos los niveles y mejorar las medidas para prevenir y reducir de manera apreciable y mensurable o eliminar el cultivo ilícito de adormidera, arbusto de coca y planta de cannabis destinado a la producción de estupefacientes y sustancias sicotrópicas, inclusive mediante la erradicación, en el marco de estrategias y medidas sostenibles de control de cultivos". 228 Este documento es la prueba de la existencia de una "inercia prohibicionista" 229 en las Naciones Unidas que evitan una y otra vez tomar en cuenta las nefastas consecuencias de la política basada en la prohibición tales como las que hemos analizado en el caso boliviano en el presente artículo.

Si bien actualmente el paradigma prohibicionista está perdiendo fuerza, aún falta un largo camino por recorrer antes de generar los consensos necesarios para discutir modificaciones de las convenciones internacionales. Bolivia, con su salida y posterior re-adhesión a la Convención Única, ha mostrado que hasta países pequeños pueden encontrar consensos a nivel internacional para introducir modificaciones a las convenciones. Se trata pues de un precedente histórico que podría inspirar a los gobiernos de otros países y que este artículo espera haber contribuido a elucidar. Del mismo modo, la opinión pública está cambiando en muchos países y demanda nuevos enfoques para las políticas públicas en materia de drogas. Por todo ello, podemos interpretar el caso boliviano como el síntoma de un cambio de paradigma global que, esperemos, permita superar en el futuro el prohibicionismo punitivo plasmado en las convenciones.

\subsection{Bolivia tiene que modificar su legislación de drogas}

Por otro lado, nuestro estudio concluye que la normativa vigente relativa a las drogas en el ordenamiento jurídico boliviano deber ser reformada en profundidad si bien la reciente Ley

\footnotetext{
227 BARATTA, Alessandro, Criminología y Sistema Penal. Compilación in memoriam, Buenos Aires: Editorial B de F, 2004, p. 308.

${ }^{228}$ Así lo estipula el Punto 3 letra d. del documento final del UNGASS de 2016 disponible en: http://www.unodc.org/documents/postungass2016//outcome/V1603304-S.pdf [visitado el 13.05.2017].

${ }^{229}$ BARRUSIO ALONSO, Martín, "Las Naciones Unidas y la política internacional de control de drogas: factores para una inercia prohibicionista”, en ARANA, Xavier y al. (coords.), Drogas: cambios sociales y legales ante el tercer milenio, Madrid: Dykinson, 2000, pp. 139-162, p. 139.
} 


\section{STIPPEL, Jörg; SERRANO, Juan. "La nacionalización de la lucha contra el narcotráfico en Bolivia".}

General de Coca representa un avance en este sentido. El legislador boliviano no necesita esperar a la reforma de los tratados internacionales para revisar su normativa adoptando, en nuestra opinión, el enfoque de "derecho penal mínimo" ${ }^{230}$ haciendo que las sanciones penales y las penas sean proporcionales al daño social causado por la infracción juzgada. Una forma de dar vigencia al principio de proporcionalidad es establecer umbrales para entregar de esa manera criterios claros a los operadores del sistema. Ecuador por ejemplo ha tenido experiencias muy positivas con este sistema. ${ }^{231}$ Es difícil, por ejemplo, entender hoy día en Bolivia cuál es el daño social causado por la persona que colecta hojas de marihuana, conducta castigada con 1 a 2 años de presidio y en caso de reincidencia de 2 a 4 años. ${ }^{232}$ Del mismo modo, el castigo de 10 a 25 años de privación de libertad previsto para el tráfico ilícito, eso incluye el (micro) tráfico de cantidades menores. ${ }^{233}$ Podemos entender que esta medida produce más problemas de las que pretende resolver. Urge por tanto revisar o incluso derogar parte de las normas penales vigentes de la Ley 1008.

Otro tema que se debe llevarse al debate público en Bolivia es la del bien jurídico verdaderamente protegido por la legislación de drogas. Cabe preguntarse entonces si podemos hacer de la salud pública el bien jurídico a proteger en un escenario en que están legalizadas las drogas más dañinas para ese bien. ${ }^{234}$ En el caso boliviano tendríamos que preguntarnos ¿qué bien jurídico se quiere proteger con normas que castigan, entre otros, el acto de colectar hojas de marihuana? ${ }^{235}$

Sentado todo lo anterior, podemos concluir que Bolivia todavía está lejos de haber racionalizado completamente su política de lucha anti-narcótica. La parte penal de Ley 1008 sigue vigente hoy día. No obstante la nacionalización de la política de drogas iniciada en el gobierno de Morales ha abierto nuevas posibilidades para reformar la legislación. Las presiones ejercidas durante la época de la "guerra contra las drogas" ya no son excusa para

\footnotetext{
230 El criminólogo italiano Alessandro Baratta aboga así por lo que él denomina el "principio de proporcionalidad concreta" y "principio de adecuación del costo social". BARATTA, "Principios", cit. nota $\mathrm{n}^{\circ} 231$, p. 310.

${ }^{231}$ Paladines describe como, tras la puesta en vigencia del Código Integral Penal, se definieron umbrales para identificar cantidades mínimas, medianas y máximas de drogas. En base a estas cantidades, los juzgados tuvieron que aplicar el principio de favorabilidad, ajustando las penas impuestas. A consecuencia de ello, más que 2000 personas recluidas en su mayoría por la posesión de cantidades mínimas o medianas de sustancias controladas, fueron beneficiados, entre ellos detenidos que cumplían penas de 8 años por haber poseído 4 gramos de marihuana. PALADINES, Jorge, En busca de la prevención perdida: reforma y contrarreforma de la política de drogas en Ecuador, Quito: FES-ILDIS, abril 2016, p. 34.

${ }^{232}$ Artículo 46 de la Ley 1008.

${ }^{233}$ Artículo 48 de la Ley 1008.

${ }^{234}$ Hermosilla recuerda que Chile fue el último país de Occidente en prohibir las drogas, pues hasta el año 1968 no tenía ninguna legislación ni control sobre drogas. Afirma que en ese entonces el problema de salud de los chilenos era el mismo como hoy día: el tabaco y el alcohol. HERMOSILLA, Juan Pablo; "Política", cit. nota $\mathrm{n}^{\mathbf{0}} 4$, pp. 38 y s.

${ }^{235}$ Bustos Ramírez analiza la problemática del bien jurídico y la perspectiva ético jurídica en relación a la legislación sobre drogas. Señala que "el único bien jurídico autónomo que se puede encontrar en estos delitos de drogas es el de la salud pública. Pero entonces surge la cuestión de saber si realmente se puede justificar que se está protegiendo la salud pública“. A su parecer es "a lo menos contradictorio, que siendo toda droga nociva para la salud, sólo se sancione los actos en relación a algunas y no de otras. BUSTOS RAMÍREZ, Juan, Coca-Cocaína, cit. nota n $\mathrm{n}^{\mathrm{T}} 72$, p. 96 y s.
} 
Polit. crim. Vol. 13, № 25 (Julio 2018) Art. 8, pp. 264-321.

[http://www.politicacriminal.cl/Vol_13/n_25/Vol13N25A8.pdf]

mantener la política prohibicionista consagrada en la Ley $1008 .{ }^{236}$ Se abre de esta manera un nuevo escenario abierto donde los futuros gobiernos del Estado Plurinacional de Bolivia pueden llegar sentar importantes precedentes para la comunidad internacional.

${ }^{236}$ Bustos Ramírez pregunta en cuanto a la legislación de drogas: “¿Qué resta para el Derecho Penal? Muy poco, pero precisamente lo suficiente para una efectiva protección de acuerdo con el respeto de los Derechos Humanos de todos. El diseño prioritario de prevención y tratamiento, por una parte, y de ayuda económica por otra, implica no una prohibición penal máxima como sucede ahora, sino por el contrario que tal prohibición sea mínima." BUSTOS RAMÍREZ, Juan, Coca-Cocaína, cit. nota nº 72, p. 144. 
STIPPEL, Jörg; SERRANO, Juan. "La nacionalización de la lucha contra el narcotráfico en Bolivia".

\section{Bibliografía}

ABBOTT, Michael H., "The Army and the Drug War: Politics or National Security?", Parameters, (diciembre 1988), pp. 95-112, en: http://www.dtic.mil/dtic/tr/fulltext/u2/a528135.pdf [visitado el 07.05.2017].

ACHÁ, Rose M., Consumo y consumidores de drogas en Bolivia, Colectivo de Estudios de Drogas y Derecho, en: http://www.drogasyderecho.org/publicaciones/prop_del/bolivia-usuarios.pdf [visitado el 25.02.2017].

ACHÁ, Rose M., Desproporcionalidad en el sistema penal antidrogas boliviano, Colectivo de Estudios de Drogas y Derecho, 2011, en: http://www.drogasyderecho.org/publicaciones/pub-bol/proporcionalidad-bolivia.pdf [visitado el 25.02.2017].

AGUILÓ, Federico, “Nunca Más” para Bolivia, Cochabamba: APDHB, 1993.

ALBÓ, Xavier, Movimientos y poder indígena en Bolivia, Ecuador y Perú, La Paz: CIPCA, 2008.

ARANA, Xabier; MARKEZ, Iñaki; VEGA, Amando, Drogas-Cambios sociales y legales ante el tercer milenio, Madrid: Editorial Dykinson, 2000.

BARATTA, Alessandro, Criminología y Sistema Penal. Compilación in memoriam, Buenos Aires: Editorial B de F, 2004.

BUSTOS RAMÍREZ, Juan, Coca-Cocaína - Política Criminal de la Droga, Editorial Jurídica ConoSur, Santiago de Chile, 1995.

CICAD; OEA, Bolivia. Evaluación del Progreso de Control de Drogas. Mecanismo de Evaluación Multilateral 1999-2000, 1999, en: http://www.cicad.oas.org/mem/reports/1/Full_Eval/Bolivia_spa.rev2.pdf [visitado el 25.02.2017].

CICAD, Bolivia. Evaluación del Progreso de Control de Drogas 2000-2001, 2001, en: http://www.cicad.oas.org/mem/reports/2/Full_Eval/Bolivia\%20-\%20esp.pdf [visitado el 25.02.2017].

CICAD, Bolivia. Evaluación del Progreso de Control de Drogas 2001-2002, 2002, en:

http://www.cicad.oas.org/mem/reports/2/Full_Eval/Bolivia\%20-\%20esp.pdf [visitado el 12.06.2017].

CICAD; OEA, Bolivia. Evaluación del Progreso de Control de Drogas 2005-2006, 2006, en: $\quad$ http://www.cicad.oas.org/mem/reports/4/Full_Eval/Bolivia\%20\%20Fourth\%20Round\%20-\%20ESP.pdf [visitado el 25.02.2017]. 
Polít. crim. Vol. 13, № 25 (Julio 2018) Art. 8, pp. 264-321.

[http://www.politicacriminal.cl/Vol_13/n_25/Vol13N25A8.pdf]

CICAD; OEA, Bolivia. Evaluación del Progreso de Control de Drogas 2007-2009, 2010, en: $\quad$ http://www.cicad.oas.org/mem/reports/5/Full_Eval/Bolivia\%20$\% 205$ ta\%20Rd\%20-\%20ESP.pdf [visitado el 25.02.2017].

CICAD; OEA, Estrategia hemisférica sobre drogas. Plan de acción 2011-2015, 2010, en: http://www.cicad.oas.org/main/aboutcicad/basicdocuments/Estrategia_drogas.pdf [visitado el 25.02.2017].

CICAD; OEA, Plan de Acción Hemisférico sobre Drogas, 2016-2020, 2016 en: http://www.cicad.oas.org/mem/Activities/PoA/PoA-Version_Final-ESP.pdf [visitado el 25.02.2017].

COLECTIVO DE ESTUDIOS DE DROGAS Y DERECHO, En busca de los derechos: Usuarios de drogas y las respuestas estatales en América Latina, México: CEDD, 2014, en: https://www.wola.org/sites/default/files/Drug\%20Policy/CEDDReporte_Completo\%209\%20julio.pdf [visitado el 25.02.2017].

CONALTID, Estrategia de lucha contra el narcotráfico y revalorización de la hoja de coca 2007-2010, La Paz: CONALTID, 2007, en http://www.embajadadebolivia.com.ar/m_documentos/img-documentos/05coca.pdf [visitado el 24.02.2017].

CONALTID, Estrategia de lucha contra el narcotráfico y reducción de cultivos excedentarios de coca 2011-2015, La Paz: CONALTID, 2011, en http://www.cicad.oas.org/fortalecimiento_institucional/planesNacionales/Bolivia_2 011_2015.pdf [visitado el 24.02.2017].

CONALTID, Boletín Informativo, julio 2014, en: http://conaltid.gob.bo/web/views/layout/assets/frontend/boletines/boletin-2014.pdf [visitado el 24.02.2017].

CRISIS GROUP, "Coca, droga y protesta social en Bolivia y Perú", Informe sobre América Latina, $\quad \mathrm{N}^{\circ} 12, \quad 3$ de marzo de 2005, en: https://www.files.ethz.ch/isn/27322/012_coca_drugs_and_social_protest_in_bolivia _and_peru_sp.pdf [visitado el 07.05.2017]

DEL OLMO, Rosa, ¿Prohibir o domesticar? Políticas de drogas en América Latina, Caracas: Editorial Nueva Sociedad, 1992.

DIEZ RIPOLLES, José Luis, "El control penal del abuso de drogas: una valoración político-criminal”, Revista de derecho de la Universidad Austral de Chile, vol.18, n 1 (2005), pp. 199-212, en: http://www.scielo.cl/scielo.php?script=sci_arttext\&pid=S071809502005000100008, [visitado el 07.05.2017].

DIRECCIÓN GENERAL DE RÉGIMEN PENITENCIARIO, "Plan Estratégico Nacional de la Dirección General de Régimen Penitenciario 2016 -2020”, 2016, Documento interno no publicado. 
STIPPEL, Jörg; SERRANO, Juan. "La nacionalización de la lucha contra el narcotráfico en Bolivia”.

ERREJÓN, Iñigo; MOUFFE, Chantal, Construir pueblo. Hegemonía y radicalización de la democracia, Madrid: Icaria, 2015.

FERNÁNDEZ CARRASQUILLA, Juan “Alternativa en la política criminal de las drogas en América Latina", Anuario de derecho penal y ciencias penales, Tomo 41 (1988), pp. 387-412.

FOUCAULT, Michel, Vigilar y castigar: el Nacimiento de la prisión, Buenos Aires: Siglo XXI, 1983.

FUNDACIÓN KONRAD ADENAUER, Jurisprudencia del Tribunal Constitucional Federal Alemán. Extractos de las sentencias más relevantes compiladas por Jürgen Schwabe, KAS: México DF, 2009, en http://www.kas.de/wf/doc/kas_16817-544-430.pdf [visitado el 07.05.2017].

GARAT, Guillermo, El camino. Cómo se reguló el cannabis en Uruguay según sus actores políticos y sociales, Montevideo: Friedrich Ebert Stiftung, Junta Nacional de Drogas, 2014, en: http://library.fes.de/pdf-files/bueros/uruguay/11201.pdf [visitado el 13.05.2017].

GARCÍA LINERA, Álvaro y al., Pensando el mundo desde Bolivia. II Ciclo de Seminarios Internacionales, La Paz: Vicepresidencia del Estado plurinacional de Bolivia, 2011.

GARCÍA LINERA, Álvaro, La potencia plebeya. Acción colectiva e identidades indígenas, obreras y populares en Bolivia, Buenos Aires: CLACSO, 2009.

GARCÍA PULGARÍN, Alex, "Narcotráfico en Colombia. Un problema creado en otra parte, importado y asumido como propio", Estudios de Derecho, vol. 67 nº149, 2010, pp. 262-281.

GLOBAL COMMISSION ON DRUG POLICY, Asumiendo el control: Caminos hacia políticas de drogas eficaces, Global Commission on Drug Policy, 2014, en: https://static1.squarespace.com/static/53ecb452e4b02047c0779e59/t/5568b6a9e4b0 867018e16784/1432925865061/AF_global_comission_Espanhol_FINAL.pdf [visitado el 08.05.2017].

GLOBAL COMMISSION ON DRUG POLICY, Avanzando la reforma de la política de drogas: Un nuevo enfoque para la descriminalización, Global Commission on Drug Policy, 2016, en: http://www.globalcommissionondrugs.org/wpcontent/uploads/2016/11/GCDP-Report-2016_ES.pdf [visitado el 08.05.2017].

GIACOMAN A., Diego, "Lucha contra el narcotráfico y situación carcelaria en Bolivia", WOLA, mayo 2010, en https://www.wola.org/sites/default/files/downloadable/Drug\%20Policy/2011/63/sistemas\%20sobrecargados\%20-\%20completo\%20bolivia.pdf [visitado el 24.02.2017].

GOOD, Pete, Bolivia-Between a Rock and a Hard Place, La Paz: Plural Editores, 2006. 
Polit. crim. Vol. 13, № 25 (Julio 2018) Art. 8, pp. 264-321.

[http://www.politicacriminal.cl/Vol_13/n_25/Vol13N25A8.pdf]

GUTIÉRREZ RAMO, Axayácatl, "Drogas: La Historia que hace falta”, Revista de la Universidad de México, Diciembre 2003-Enero 2004, pp. 45-53, en: http://www.revistadelauniversidad.unam.mx/ojs_rum/files/journals/1/articles/15971/ public/15971-21369-1-PB.pdf [visitado el 13.05.2017].

HERMOSILLA, Juan Pablo; "Política de Control de Drogas. Reformas urgentes hacia la Descriminalización”, Nova Criminis, nº 8, vol. 5 (diciembre 2014) , pp. 31 -57.

IGLESIAS, Pablo; ESPASANDÍN, Jesús (coords.), Bolivia en Movimiento. Acción Colectiva y Poder Político, Barcelona: El Viejo Topo, 2007.

INSTITUTO NACIONAL DE ESTADÍSTICA, Anuario Estadístico 2004, La Paz: INE, 2004, en: http://inecloud.ine.gob.bo/inecloud/index.php/s/hv4IjoAsCQgeVlx ; [visitado el 13.05.2017].

INSTITUTO NACIONAL PENITENCIARIO, Informe Estadístico Penitenciario, Lima: INE, Enero 2016, en: http://www.inpe.gob.pe/pdf/enero_2016.pdf [visitado el 08.05.2017].

INSTITUTO NACIONAL PENITENCIARIO Y CARCELARIO, Informe Estadístico, Bogotá: INPEC, Enero 2016, en: http://www.inpec.gov.co/portal/page/portal/Inpec/Institucion/Estad\%EDsticas/Estad isticas/Informes\%20y\%20Boletines \%20Estad\%EDsticos/01\%20INFORME\%20EN ERO\%202016_.pdf [visitado el 08.05.2017].

INTERNATIONAL DRUG POLICY CONSORTIUM, "La reconciliación jurídica de Bolivia con la Convención Única sobre Estupefacientes", 2011, en: https://www.tni.org/files/publication-downloads/idpc-advocacy-note_boliviawithdraws-from-single-convention-spa.pdf [visitado el 24.02.2017].

INTERNATIONAL MONETARY FUND, Bolivia. Ex-Post Assessment of Longer-Term Program Engagement, Country Report n05/139 (abril 2005), en https://www.imf.org/external/pubs/ft/scr/2005/cr05139.pdf [visitado el 24.02.2017].

JELSMA, Martin, "The development of international drug control: lessons learned and strategic challenges for the future", Working Paper Prepared for the First Meeting of the Commission Geneva, 24-25 January 2011, 2011, en: http://www.globalcommissionondrugs.org/wpcontent/themes/gcdp_v1/pdf/Global_Com_Martin_Jelsma.pdf [visitado el 07.05.2017].

JELSMA, Martin; ARMENTA, Amira, Las convenciones de drogas de la ONU. Guía Básica, Octubre 2015, en: https://www.tni.org/files/publicationdownloads/primer_unconventions_24102015-es.pdf [visitado el 07.05.2017].

JUNTA INTERNACIONAL DE FISCALIZACIÓN DE ESTUPEFACIENTES, Informe de la Junta Internacional de Fiscalización de Estupefacientes correspondiente a 1999 (E/INCB/1999/1), 1999 ,

en: 
STIPPEL, Jörg; SERRANO, Juan. "La nacionalización de la lucha contra el narcotráfico en Bolivia”.

https://www.incb.org/documents/Publications/AnnualReports/AR1999/AR_1999_S. pdf [visitado el 25.02.2017].

JUNTA INTERNACIONAL DE FISCALIZACIÓN DE ESTUPEFACIENTES, Informe de la Junta Internacional de Fiscalización de Estupefacientes correspondiente a 2016 (E/INCB/2016/1), 2017,

en: https://www.incb.org/documents/Publications/AnnualReports/AR2016/Spanish/AR 2016_S_ebook.pdf [visitado el 12.06.2017].

JOIGNANT, Alfredo, "La politique des "transitologues": Luttes politiques, enjeux théoriques et disputes intellectuelles au cours de la transition chilienne à la démocratie", Politique et Sociétés, vol. 24, n² 2-3, (2005), pp. 33-59.

LASERNA, Roberto, El fracaso del prohibicionismo Estudios socioeconómicos para una historia de las políticas antidrogas en Bolivia, La Paz: Fundación Vicente Pazos Kanki, 2011, en: http://www.bivica.org/upload/politicas-antidrogas.pdf [visitado el 07.05.2017].

LAZARTE, Jorge, Hacia un país moderno y democrático. La Asamblea Constituyente: un nuevo comienzo, La Paz: Plural editores, 2006.

MAYORGA, René A., "La crisis del sistema de partidos políticos en Bolivia: causas y consecuencias". Cuaderno del Cendes, vol.21, n.57 (2004), pp. 83-114, en http://www.scielo.org.ve/scielo.php?script=sci_arttext\&pid=S1012

25082004000300005\&lng=es\&nrm=iso [visitado el 24.02.2017].

MAYORGA, René A., "Presidencialismo parlamentarizado y gobiernos de coalición en Bolivia", en: LANZARO, Jorge (Comp.), Tipos de presidencialismo y coaliciones políticas en América Latina, Buenos Aires: CLACSO, 2001, pp. 101-135, p. 106, en http://biblioteca.clacso.edu.ar/clacso/gt/20101028013651/lanzaro.pdf [visitado el 24.02.2017].

MESA GISBERT, Carlos D., Historia de Bolivia, La Paz: Novena edición, Editorial Gisbert y CIA S.A., 2016 (1997).

MESA GISBERT, Carlos D., Presidencia sitiada. Memorias de mi Gobierno, La Paz: Quinta edición, Plural editores, 2013 (2008).

MESA GISBERT, Carlos D., Bolivia 1982-2006. Democracia, La Paz: Editorial Gisbert y CIA S.A., 2017.

MINISTERIO DE PREVISIÓN SOCIAL Y SALUD PÚBLICA, La prevalencia del uso indebido de drogas en Bolivia (población urbana), 1993, en: http://pdf.usaid.gov/pdf_docs/Pnado265.pdf [visitado el 24.02.2017].

MOUFFE, Chantal, En torno a lo político, Buenos Aires: Fondo de Cultura Económica, 2007.

NACIONES UNIDAS, Comentarios a la Convención Única de 1961 sobre Estupefacientes, Naciones Unidas: 1989, en: 
Polít. crim. Vol. 13, № 25 (Julio 2018) Art. 8, pp. 264-321.

[http://www.politicacriminal.cl/Vol_13/n_25/Vol13N25A8.pdf]

http://www.unodc.org/documents/treaties/organized_crime/Drug\%20Convention/C omentarios_a_la_convencion_unica_de_1961.pdf [visitado el 24.02.2017].

OBSERVATORIO EUROPEO DE LAS DROGAS Y LAS TOXICOMANÍAS, Informe Europeo sobre Drogas 2016: Tendencias y novedades, Luxemburgo: Oficina de Publicaciones de la Unión Europea, 2016, en: http://www.emcdda.europa.eu/system/files/publications/2637/TDAT16001ESN.pdf [visitado el 08.05.2017].

OBSERVATORIO DE DROGAS DE COLOMBIA, Reporte de drogas de Colombia 2016, Bogotá: Ministerio de Justicia y del Derecho, 2016, en: http://www.odc.gov.co/Portals/1/publicaciones/pdf/odc-libroblanco/ODC0100322016_reporte_drogas_colombia_2016.pdf [visitado el 08.05.2017].

OBSERVATORIO DEL NARCOTRÁFICO EN CHILE, Informe 2015, Santiago de Chile: Ministerio Público de Chile, 2015, en http://www.senda.gob.cl/media/estudios/otrosEstudios/2015_Primer_informe_obser vatorio_narcotrafico.pdf [visitado el 08.05.2017].

PALADINES, Jorge, En busca de la prevención perdida: reforma y contrarreforma de la política de drogas en Ecuador, Quito: FES-ILDIS, abril 2016.

PALADINES, Jorge Vicente (coord.), El Equilibrio Perdido: drogas y proporcionalidad en las justicias de América, Quito: Defensoría Pública del Ecuador, 2013.

PINTO OCAMPO, María T., "Entre la represión y la concertación: los cocaleros en el Chapare y en el Putumayo", Informe final del concurso: Movimientos sociales y nuevos conflictos en América Latina y el Caribe, Programa Regional de Becas CLACSO (2004) en: http://biblioteca.clacso.edu.ar/clacso/becas/20110127090256/pinto.pdf [visitado el 25.02.2017].

POLICÍA NACIONAL DEL PERÚ, Anuario Estadístico, Lima: Ministerio del Interior, 2015 ,

en: https://www.pnp.gob.pe/anuario_estadistico/documentos/ANUARIO\%20PNP\%202 015\%20DIREST\%20PUBLICACION.pdf [visitado el 08.05.2017].

PUENTE INVESTIGACIÓN Y ENLACE; ASOCIACIÓN BOLIVIANA DE COMUNIDADES TERAUPÉTICAS, Estudio sobre drogas en pacientes en centros de tratamiento de las principales ciudades de Bolivia. Informe final 2013, 2014, en: http://www.piebolivia.org.bo/flip/estudiodrogas.pdf [visitado el 24.02.2017].

QUIROGA, José Antonio, Coca/Cocaína. Una visión boliviana, La Paz: AIPEPROCOM/CEDLA/CID, 1990, en: https://www.cedla.org/sites/default/files/M0858_coca_cocaina_una_vision_boliviana.pdf [visitado el 07.05.2017]. 
STIPPEL, Jörg; SERRANO, Juan. "La nacionalización de la lucha contra el narcotráfico en Bolivia”.

RONCKEN, Theo; ACHÁ, Gloria, Vivir bien y Estado penal. Políticas que no riman, Cochabamba: Acción Andina y Colectivo de Estudios de Drogas y Derecho, 2013, en:

https://www.wola.org/sites/default/files/Drug\%20Policy/Vivir\%20Bien\%20y\%20Es tado\%20Penal\%20BO.pdf [visitado el 25.02.2017].

ROSENAUER, Cecilia; STIPPEL, Jorg, El Nuevo Código de Procedimiento Penal. De la Teoría a la Práctica. La Paz: Plural Editores, 2001.

SÁENZ URIBE, Sara, “Consumo de drogas ilícitas, ¿prohibición o regulación?. Análisis del caso colombiano en perspectiva de política comparada", Revista Facultad de Derecho y Ciencias Políticas, vol. 39, núm. 111, (julio-diciembre, 2009), pp. $253-$ 282, en: http://www.redalyc.org/pdf/1514/151412839003.pdf [visitado el 07.05.2017].

SALAZAR, Fernando, "El Plan Dignidad y el militarismo en Bolivia. El caso del Trópico de Cochabamba", Buenos Aires: CLACSO, 2003, en: http://biblioteca.clacso.edu.ar/clacso/formacionvirtual/20100724065836/11salazar.pdf [visitado el 25.02.2017].

SERRAMO MORENO, Juan E., "La exhumación de 1979 en Murcia. Acción colectiva de familiares de fusilados republicanos durante la transición", Ayer. Revista de Historia Contemporánea, 103/2016 (3), pp. 147-177.

SISTEMA NACIONAL DE ESTADÍSTICAS DE EJECUCIÓN DE LA PENA, Informe Anual 2015, Buenos Aires: Ministerio de Justicia y Derechosa Humanos, en: http://www.jus.gob.ar/media/3191517/informe_sneep_argentina_2015.pdf [visitado el 08.05.2017].

SOTO, David, "Podemos o la irrupción plebeya: nota bibliográfica", Revista Sociología Histórica, nº 5 (2015), pp. 547-563.

STEFANONI, Pablo, "El nacionalismo indígena como identidad política: La emergencia del MAS-IPSP (1995-2003)", Informe final del concurso: Movimientos sociales y nuevos conflictos en América Latina y el Caribe, Programa Regional de Becas CLACSO (2002)

en: http://bibliotecavirtual.clacso.org.ar/ar/libros/becas/2002/mov/stefanoni.pdf [visitado el 25.02.2017].

STEFANONI, Pablo; DO ALTO, Hervé., Evo Morales, de la coca al Palacio. Una oportunidad para la izquierda indígena, La Paz: Malatesta, 2006.

STIPPEL, Jorg, Las cárceles y la búsqueda de una política criminal para Chile, Santiago: LOM, 2006.

STIPPEL, Jorg, Cárcel, derecho y política. Santiago: LOM, 2013. 
Polit. crim. Vol. 13, № 25 (Julio 2018) Art. 8, pp. 264-321.

[http://www.politicacriminal.cl/Vol_13/n_25/Vol13N25A8.pdf]

STIPPEL, Jorg; SERRANO MORENO, Juan E., "Veinte años de reformas sin rumbo. De la reforma procesal penal a la cumbre de justicia en Bolivia", Nova Criminis, $\mathrm{n}^{\circ} 12$, vol.8 (diciembre 2016), pp. 33-75.

SUBDIRECCIÓN TÉCNICA DE LA GENDARMERÍA DE CHILE, Informe de Gestión 2014, Santiago de Chile. SISTEMA NACIONAL DE ESTADÍSTICAS DE EJECUCIÓN DE LA PENA, 2015, en: https://html.gendarmeria.gob.cl/doc/20141105_memoria_sdt/Memoria_SDT_2014. pdf [visitado el 08.05.2017].

TAPIA, Luis, La invención del núcleo común. Ciudadanía y gobierno multisocial, La Paz: Muela del Diablo Editores, 2006.

TAPIA, Luis, Política salvaje, La Paz: CLACSO, 2008.

TELLERÍA, Loreta; GONZÁLES, Reina, Hegemonía Territorial Fallida-Estrategias de control y dominación de Estados Unidos en Bolivia: 1985-2012, La Paz: CIS, 2015.

TRANSNATIONAL INSTITUTE, “¿Coca sí, Coca no? Opciones legales para la hoja de coca", Drogas y Conflicto. Documentos de Debate, nº13, (mayo 2006), en: http://www.undrugcontrol.info/images/stories/documents/debate13s.pdf [visitado el 25.02.2017].

TRANSNATIONAL INSTITUTE, Auge y caída de la prohibición del cannabis. La historia del cannabis en el sistema de control de drogas de la ONU y opciones de reforma, TNI: Amsterdam, 2014, en: https://www.tni.org/files/download/auge-ycaida-web.pdf [visitado el 07.05.2017].

TUDELA, Patricio, Conceptos y orientaciones para políticas de seguridad ciudadana, Santiago: CIDEPOL, 2005, en: http://www.investigaciones.cl/cidepol/biblioteca/conceptosyorientaciones.pdf [visitado el 25.02.2017].

UGARTE, Henry "Loza: Proyecto de ley de la coca prevé garantizar 20 mil hectáreas e incluye impuestos", Los Tiempos de Cochabamba, 29 de abril 4 2016, en: http://www.lostiempos.com/actualidad/nacional/20160429/loza-proyecto-ley-cocapreve-garantizar-20-mil-hectareas-e-incluye [visitado el 24.02.2017].

UNITED STATES DEPARTMENT OF STATE, International Narcotics Control, Strategy Report. Volume I Drug and Chemical Control, marzo 2015, Bureau for International Narcotics and Law Enforcement Affairs, en: https://www.state.gov/documents/organization/239560.pdf [visitado el 25.02.2017].

UNODC, "Bolivia vuelve al convenio sobre drogas de la ONU, mientras que hace una excepción en cuanto a masticación de hoja de coca", 16 de enero 2013, en: https://www.unodc.org/lpo-brazil/es/frontpage/2013/01/16-bolivia-volta-a-aderir-aconvencao-sobre-drogas-da-onu-com-excecao-para-folha-de-coca.html [visitado el 24.02.2017]. 
STIPPEL, Jörg; SERRANO, Juan. "La nacionalización de la lucha contra el narcotráfico en Bolivia”.

UNODC, "UNODC felicita al Gobierno por el desarrollo del 'Plan Nacional de Reducción de la Demanda de Drogas' y destaca logros del proyecto de prevención", 2013, en: https://www.unodc.org/bolivia/es/stories/presentacion_plan_reduccion_demanda_de _drogas.html [visitado el 24.02.2017].

UNODC, Making the world safer from crime, drugs and terrorism, 2015, en: https://www.unodc.org/documents/brussels/EU-UNODC_10_Years_Brochure/EUUNODC-brochure_WEB.pdf [visitado el 24.02.2017].

UNODC, Bolivia. Monitoreo de Cultivos de Coca 2015, La Paz,: UNODC, 2016, en: https://www.unodc.org/documents/cropmonitoring/Bolivia/Bolivia_Informe_Monitoreo_Cultivos_Coca_2015.pdf [visitado el 08.05.2017].

UNODC, Los tratados de fiscalización internacional de drogas, 2013, en: https://www.unodc.org/documents/commissions/CND/Int_Drug_Control_Conventi ons/Ebook/The_International_Drug_Control_Conventions_S.pdf [visitado el 24.02.2017].

UNODC, Pasta Básica de Cocaína. Cuatro décadas de historia, actualidad y desafíos, , Lima: UNODC, 2013, en: https://www.unodc.org/documents/peruandecuador/Publicaciones/Publicaciones201 3/LIBRO_PBC.pdf [visitado el 13.05.2017].

VACAFLOR, Nancy, "Evo pide legalizar el cato de coca después de las elecciones", Página Siete, 21 de julio 2014, en: http://www.paginasiete.bo/nacional/2014/7/21/pide-legalizar-cato-coca-despueselecciones-27287.html [visitado el 25.02.2017].

VALVERDE, Carlos, territorio, poder y cocaína, Santa Cruz de la Sierra: El país, 2016.

VICEMINISTERIO DE DEFENSA SOCIAL Y SUSTANCIAS CONTROLADAS, Memoria Institucional 2013, 2013, en: http://www.vds.gob.bo/wpcontent/uploads/2016/04/MEMORIA-2013.pdf [visitado el 24.02.2017].

VICEPRESIDENCIA DEL ESTADO PLURINACIONAL DE BOLIVIA, Injerencia de los Estados Unidos en Bolivia. Documentos desclasificados por el Departamento de Estado de los Estados Unidos, agosto 2009, en: https://www.vicepresidencia.gob.bo/IMG/pdf/desclasificados.pdf [visitado el 25.02.2017].

YANEZ, Arturo, "Ley del sistema nacional de seguridad ciudadana. ¿Un instrumento eficaz para combatir la delincuencia en el marco del estado de derecho?", Foro Sucrense. Revista del I. Colegio de Abogados de Chuquisaca, nº12 (marzo 2004), en http://www.arturoyanezcortes.com/pdf/artrev008.pdf (ultima visita)

YOUNGERS, Coletta A., "Los daños colaterales de la "guerra contra las drogas" impulsada por Estados Unidos”, en MORALES VITERI, Juan Pablo; PALADINES, Jorge Vicente (eds.), Entre el control social y los derechos humanos. 
Polít. crim. Vol. 13, № 25 (Julio 2018) Art. 8, pp. 264-321.

[http://www.politicacriminal.cl/Vol_13/n_25/Vol13N25A8.pdf]

Los retos de la política y la legislación de drogas - Homenaje a Juan Bustos Ramírez, Quito: Ministerio de Justicia y Derechos Humanos, 2009, pp. 217-242.

ZAFFARONI, Eugenio Raúl, “La legislación anti-droga latinoamericana: Sus componentes de Derecho Penal Autoritario”, en MORALES VITERI, Juan Pablo; PALADINES, Jorge Vicente (eds.), Entre el control social y los derechos humanos-Los retos de la política y la legislación de drogas. Homenaje a Juan Bustos Ramírez, Quito: Ministerio de Justicia y Derechos Humanos, 2009, pp. 3-15. 